Franz Mauthner | Werner Weiss | Monika Spörk-Dür SOLAR HEAT WORLDWIDE Markets and Contribution to the Energy Supply 2013

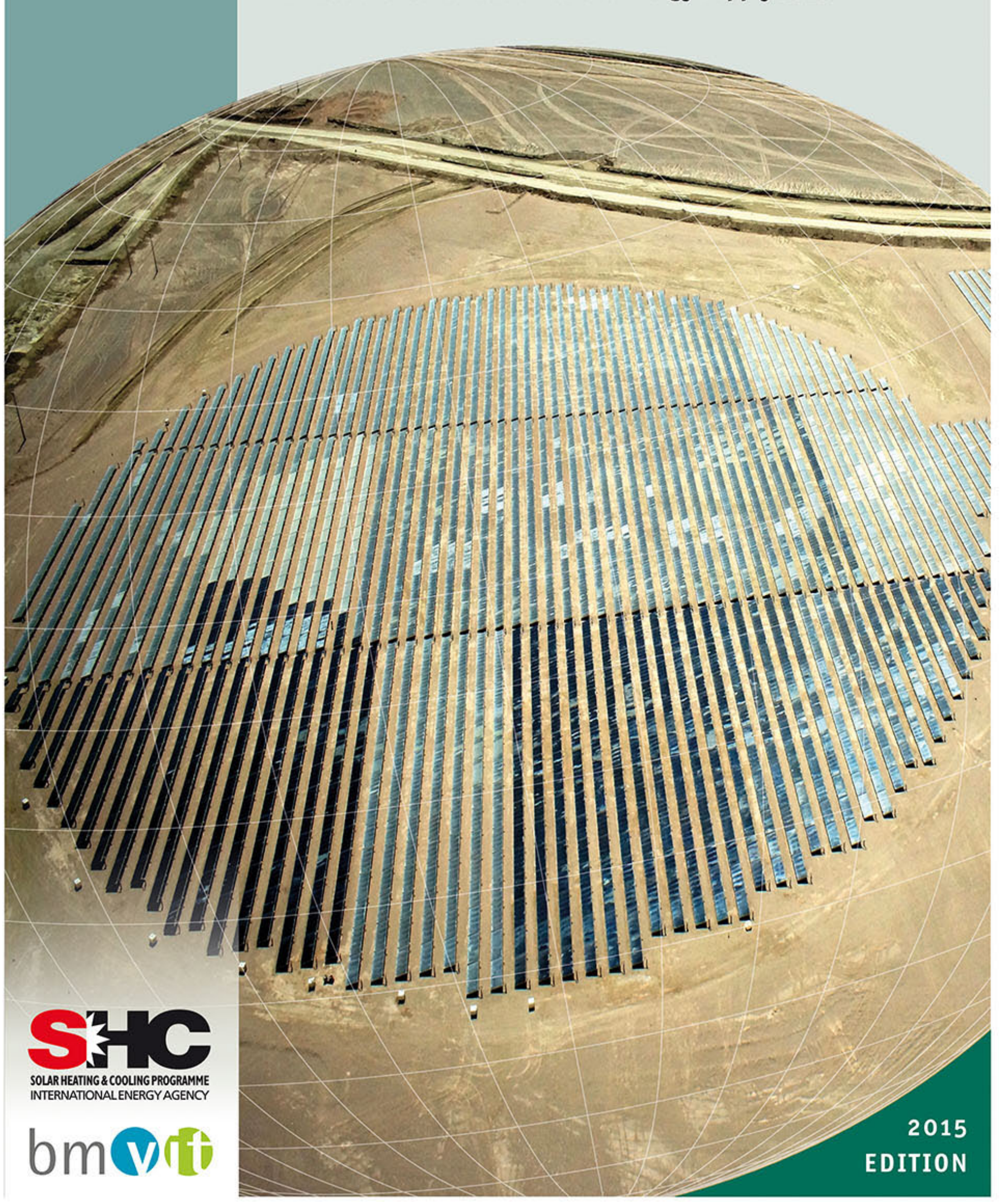





\section{SOLAR HEAT WORLDWIDE}

Markets and Contribution to the Energy Supply 2013

EDITION 2015

Franz Mauthner, Werner Weiss, Monika Spörk-Dür

AEE INTEC

AEE - Institute for Sustainable Technologies

A-8200 Gleisdorf, Austria

IEA Solar Heating \& Cooling Programme, June 2015

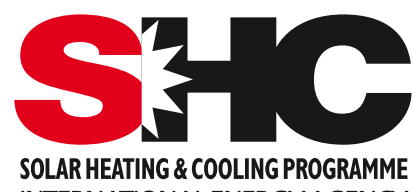

INTERNATIONALENERGY AGENCY

Supported by the Austrian Ministry for Transport, Innovation and Technology

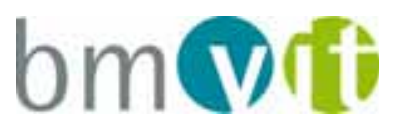

Cover: Pampa Elvira Solar - Arcon-Sunmark AS

Design, Grafics, Typesetting \& Imageprocessing: STEINHUBER INFODESIGN, Graz, Austria 


\section{Table of Contents}

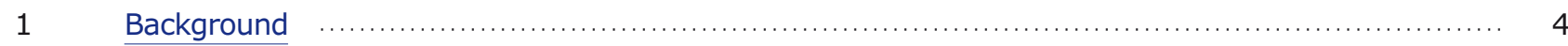

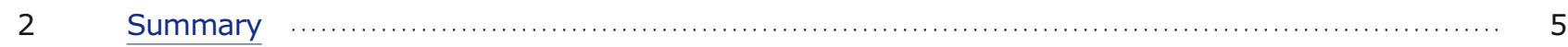

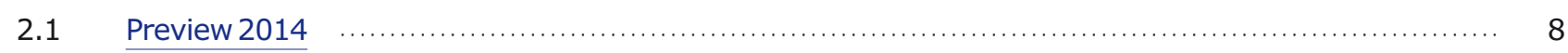

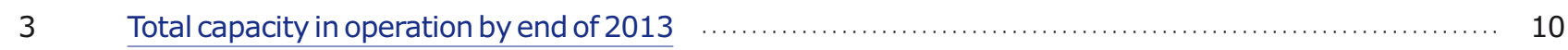

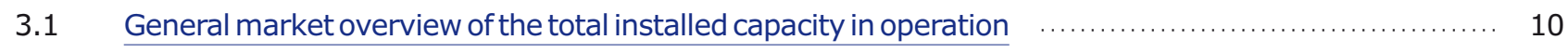

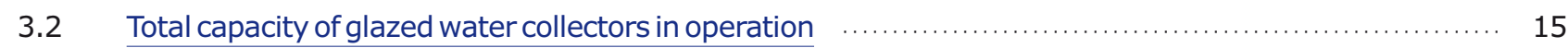

3.3 Total capacity of glazed water collectors in operation by economic region $\ldots \ldots \ldots \ldots \ldots \ldots \ldots \ldots \ldots \ldots \ldots \ldots \ldots$

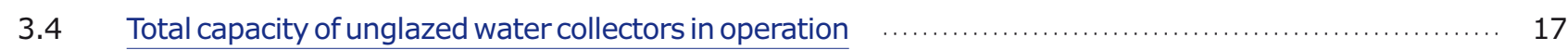

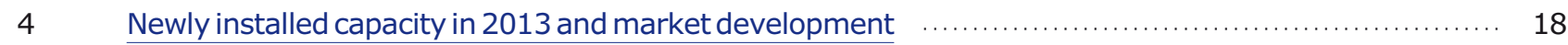

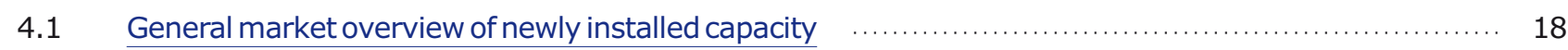

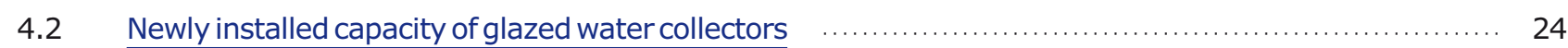

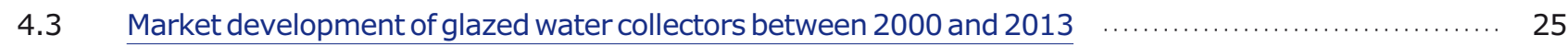

4.4 Market development of unglazed water collectors between 2000 and $2013 \quad \ldots \ldots \ldots \ldots \ldots \ldots \ldots \ldots \ldots \ldots \ldots . \ldots \ldots$

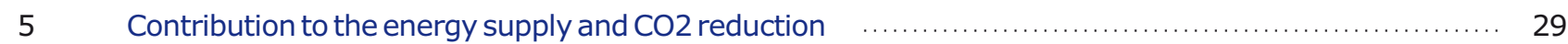

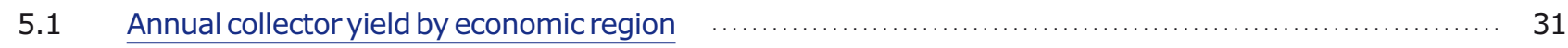

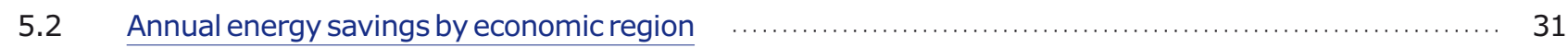

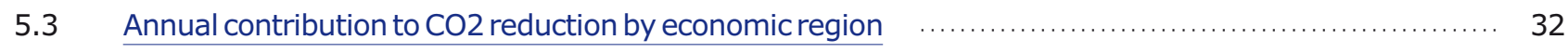

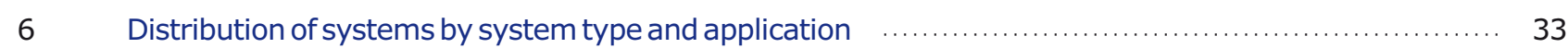

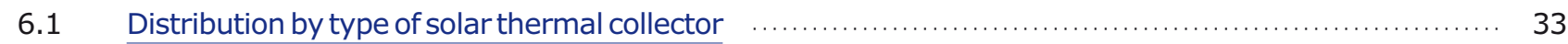

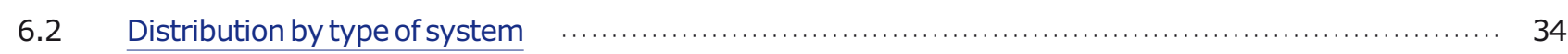

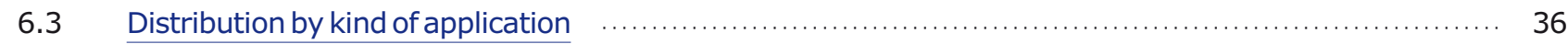

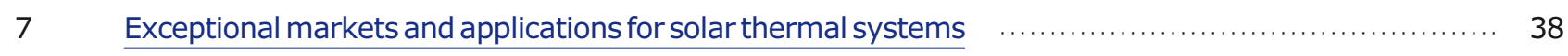

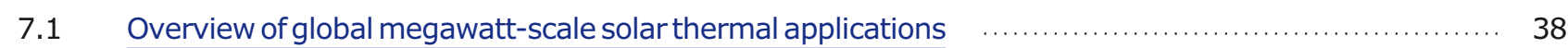

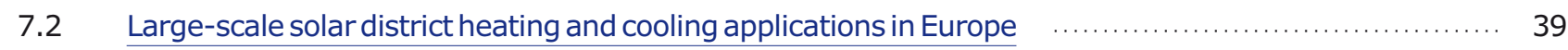

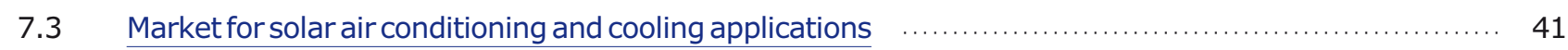

7.4 Best practice examples of worldwide installed solar process heat applications $\quad$.......................... 41

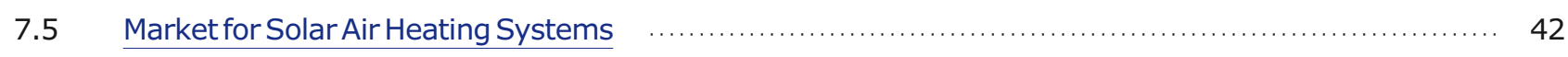

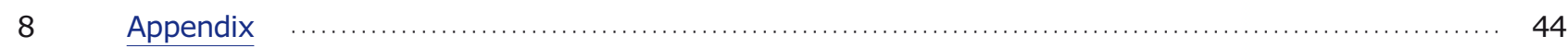

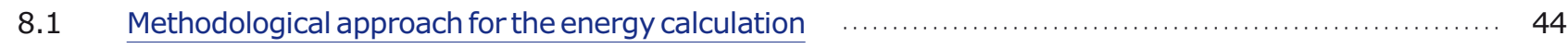

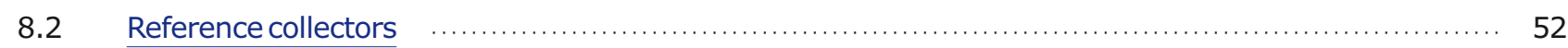

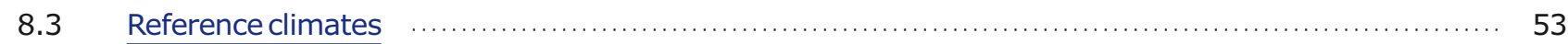

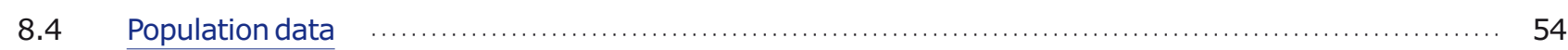

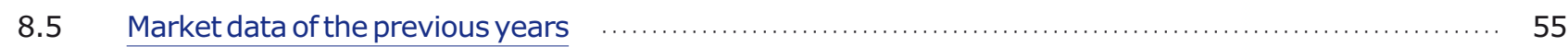

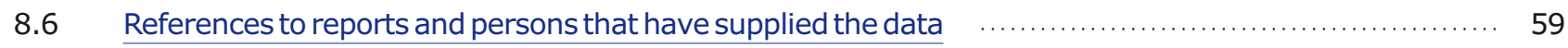

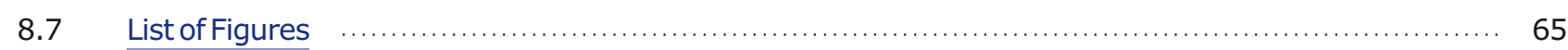

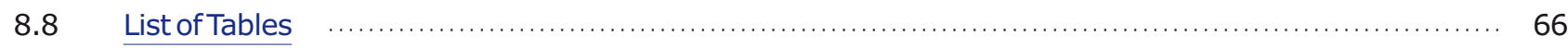




\section{$1 \quad$ Background}

This report was prepared within the framework of the Solar Heating and Cooling Programme (SHC) of the International Energy Agency (IEA). The goal of the report is to document the solar thermal capacity installed in the important markets worldwide, and to ascertain the contribution of solar thermal systems to the supply of energy and the $\mathrm{CO}_{2}$ emissions avoided as a result of operating these systems. The collectors documented are unglazed collectors, glazed flat-plate collectors (FPC) and evacuated tube collectors (ETC) with water as the energy carrier as well as glazed and unglazed air collectors.

The data were collected from a survey of the national delegates of the SHC Programme's Executive Committee and other national experts active in the field of solar thermal energy. As some of the 60 countries included in this report have very detailed statistics and others have only estimates from experts, the data was checked for its plausibility on the basis of various publications.

Starting with the collector area, respectively the capacity installed, the contributions of solar thermal systems towards the supply of energy and the reduction of $\mathrm{CO}_{2}$ were ascertained.

The 60 countries included in this report represent 4.5 billion people, or about $63 \%$ of the world's population. The installed capacity in these countries is estimated to represent $95 \%$ of the solar thermal market worldwide.

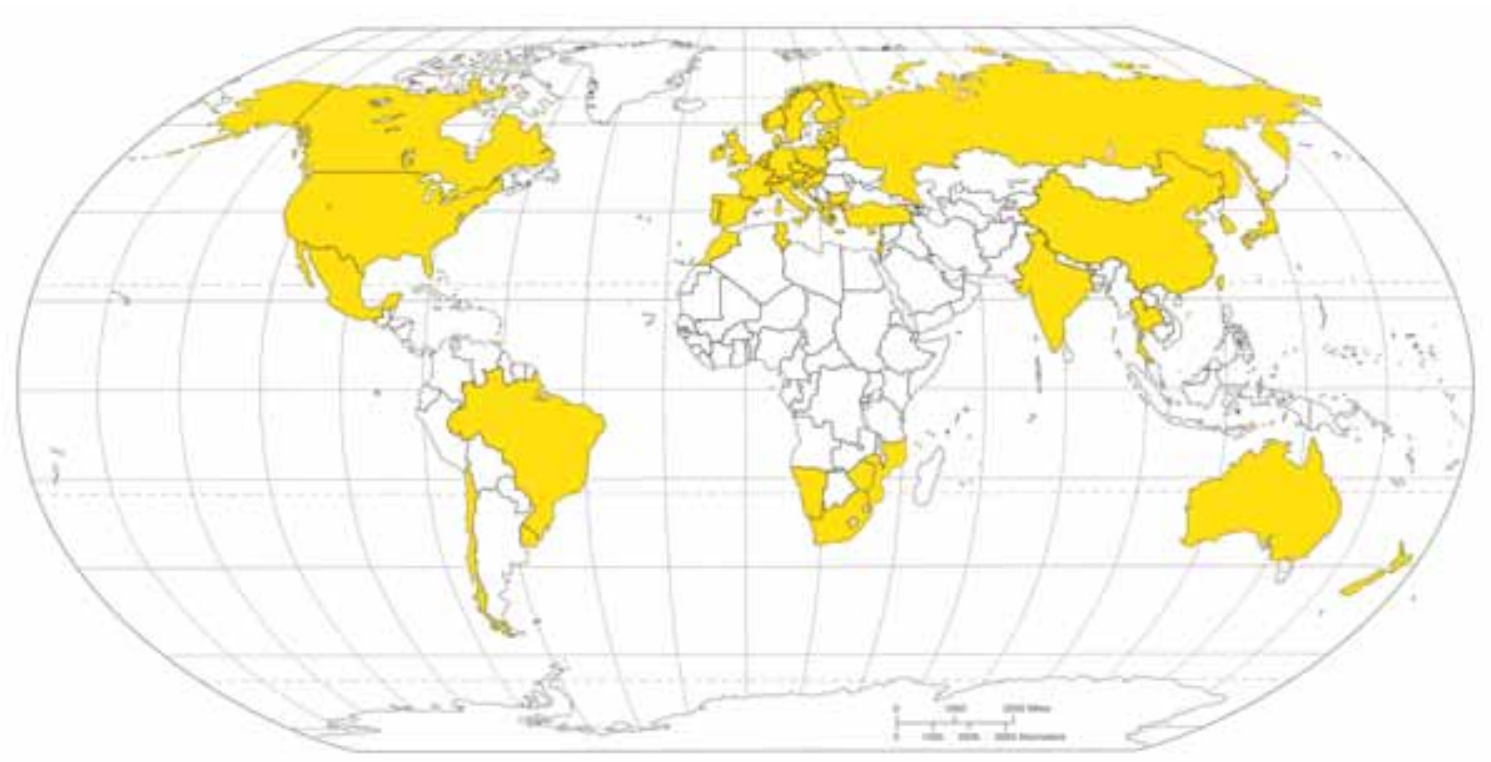

Figure 1: From countries shown in yellow detailed market data are available. The market data from all other countries are estimated. 


\section{Summary}

This report comprises solar thermal market data from 60 countries covering an estimated $95 \%$ of the worldwide market. The remaining $5 \%$ of the market were extrapolated and are labeled as "all other countries" in the following sections.

\section{Total installed capacity in operation worldwide by the end of 2013}

By the end of 2013, an installed capacity of $374.7 \mathrm{GW}_{\text {th }}$, corresponding to a total of 535 million square meters ${ }^{1}$ of collector area was in operation worldwide.

The vast majority of the total capacity in operation was installed in China (262.3 $\left.\mathrm{GW}_{\text {th }}\right)$ and Europe (44.1 $\left.\mathrm{GW}_{\text {th }}\right)$, which together accounted for $82 \%$ of the total capacity installed. The remaining installed capacity was shared between the United States and Canada $\left(17.7 \mathrm{GW}_{\text {th }}\right)$, Asia excluding China $\left(10.0 \mathrm{GW}_{\text {th }}\right)$, Latin America $\left(8.7 \mathrm{GW}_{\text {th }}\right)$, the MENA ${ }^{2}$ countries Israel, Jordan, Lebanon, Morocco, the Palestinian Territories and Tunisia $\left(6.1 \mathrm{GW}_{\text {th }}\right)$, Australia and New Zealand (5.9 $\mathrm{GW}_{\text {th }}$ ), and Sub-Sahara African countries Mauritius, Mozambique, Namibia, South Africa and Zimbabwe (1.2 GW $\mathrm{th}_{\text {th }}$ ). The market volume of "all other countries" is estimated to amount for $5 \%$ of the total installations $\left(18.7 \mathrm{GW}_{\mathrm{th}}\right)$.

The breakdown of the cumulated capacity in operation in 2013 by collector type is $22.4 \%$ glazed flat-plate collectors, $70.5 \%$ evacuated tube collectors, $6.7 \%$ unglazed water collectors, and $0.4 \%$ glazed and unglazed air collectors.

The leading countries in cumulated unglazed and glazed water collector capacity in operation in 2013 per 1,000 inhabitants were Austria (430 kWth $/ 1,000$ inhabitants), Cyprus (425 kWth $/ 1,000$ inhabitants), Israel ( $377 \mathrm{~kW}_{\mathrm{th}} / 1,000$ inhabitants), Barbados (319 kW $/ 1,000$ inhabitants), Greece $\left(271 \mathrm{~kW}_{\mathrm{th}} / 1,000\right.$ inhabitants), the Palestinian Territories (257 kWth $/ 1,000$ inhabitants), Australia (252 kW $/ 1,000$ inhabitants), China (194 kW ants), Germany (151 kWth $/ 1,000$ inhabitants) and Turkey (136 kWth $/ 1,000$ inhabitants).

\section{Newly installed capacity worldwide in 2013}

In the year 2013, a total capacity of $55.0 \mathrm{GW}_{\mathrm{th}}$, corresponding to 78.6 million square meters of solar collectors, was installed worldwide. This means an increase in new collector installations of 1.8\% compared to the year 2012 .

The main markets were in China (44.5 $\mathrm{GW}_{\text {th }}$ ) and Europe ( $3.6 \mathrm{GW}_{\text {th }}$ ), which together accounted for $87 \%$ of the overall new collector installations in 2013. The rest of the market was shared between Latin America $\left(1.2 \mathrm{GW}_{\mathrm{th}}\right)$, Asia excluding China $\left(1.0 \mathrm{GW}_{\mathrm{th}}\right)$, the United States and Canada $\left(0.8 \mathrm{GW}_{\mathrm{th}}\right)$, Australia $\left(0.6 \mathrm{GW}_{\mathrm{th}}\right)$, the MENA region represented by Israel, Jordan, Lebanon, Morocco, the Palestinian Territories and Tunisia $\left(0.5 \mathrm{GW}_{\mathrm{th}}\right)$ and the SubSahara African countries Mozambique, South Africa and Zimbabwe $\left(0.1 \mathrm{GW}_{\mathrm{th}}\right)$.). The market volume of "all other countries" is estimated to amount for $5 \%$ of the new installations ( $2.8 \mathrm{GW}$ th $)$.

To compare the installed capacity of solar thermal collectors with other energy sources, solar thermal experts agreed upon a methodology to convert installed collector area into solar thermal capacity at a joint meeting of the IEA SHC Programme and major solar thermal trade associations held September 2004 in Gleisdorf, Austria. The represented associations from Austria, Canada, Germany, the Netherlands, Sweden and United States as well as the European Solar Thermal Industry Federation (ESTIF) and the IEA SHC Programme agreed to use a factor of $0.7 \mathrm{~kW}$ th $/ \mathrm{m}^{2}$ to derive the nominal capacity from the area of installed collectors. 
The breakdown of the new installed capacity in 2013 by collector type is $17.4 \%$ glazed flat-plate collectors, $79.4 \%$ evacuated tube collectors, $3.1 \%$ unglazed water collectors and $0.1 \%$ glazed and unglazed air collectors.

The leading countries in new installed unglazed and glazed water collector capacity in 2013 per 1,000 inhabitants were Israel (38 kWth $/ 1,000$ inhabitants), China (33 kWth $/ 1,000$ inhabitants); Australia ( $26 \mathrm{~kW}_{\mathrm{th}} / 1,000$ inhabitants); the Palestinian Territories (19 kW $\mathrm{kW}_{\mathrm{th}} / 1,000$ inhabitants); Turkey (17 kW $\mathrm{kh} / 1,000$ inhabitants); Austria (15 $\mathrm{kW}_{\mathrm{th}} / 1,000$ inhabitants); Greece (15 kW $\mathrm{kh} / 1,000$ inhabitants); Denmark (13 kW $\mathrm{th} / 1,000$ inhabitants); Switzerland $\left(12 \mathrm{~kW}_{\mathrm{th}} / 1,000\right.$ inhabitants) and Cyprus (11 kWth $/ 1,000$ inhabitants).

\section{Contribution to the energy supply and $\mathrm{CO}_{2}$ reduction}

The annual collector yield of all water-based solar thermal systems in operation by the end of 2013 in the 60 recorded countries was $314 \mathrm{TWh}(=1,129 \mathrm{PJ})$. This corresponds to an energy savings equivalent of 33.7 million tons of oil and 109 million tons of $\mathrm{CO}_{2}$. The calculated number of different types of solar thermal systems in operation was around 111 million.

In $2013,94 \%$ of the energy provided by solar thermal systems worldwide was used for heating domestic hot water, mainly by small-scale systems in single family houses (84\%) and larger applications attached to multi-family houses, hotels, schools, etc. (10\%). Swimming pool heating held a share of $4 \%$ in the contribution to the energy supply and $\mathrm{CO}_{2}$ reduction and the remaining $2 \%$ was met by solar combi-systems.

Globally, in 2013 solar thermal contributed about $1.2 \%$ to the overall domestic hot water and space heating demand in buildings ${ }^{3}$.

\section{Distribution of systems by system type and application}

The thermal use of the sun's energy varies greatly from region to region across the globe. It can be roughly distinguished by the type of solar thermal collector used (unglazed water collectors, evacuated tube collectors, flat plate collectors, glazed and unglazed air collectors, concentrating collectors), the type of system operation (pumped solar thermal systems, thermosiphon systems), and the main type of application (swimming pool heating, domestic hot water preparation, space heating, heating of industrial processes, solar district heating or solar thermal cooling).

For unglazed and glazed water collectors, the evacuated tube collector dominated with a $71 \%$ share of the cumulated capacity in operation and a 79\% share of the new installed capacity. In China, vacuum tube collectors played an important role, and since this was by far the largest market, the worldwide figures tend towards a higher share of this type of solar thermal collector.

Unglazed water collectors accounted for $7 \%$ of the cumulated water collectors installed worldwide and the share tended to decrease. In 2013 the share of unglazed water collectors was 3\% of the new installed capacity.

Worldwide, around $77 \%$ of all solar thermal systems installed are thermosiphon systems and $23 \%$ are pumped solar heating systems. Similar to the distribution by type of solar thermal collector in total numbers, the Chinese market influenced the overall figures most, and in 2013 90\% of the new installed systems were estimated to be thermosiphon systems while pumped systems only accounted for $10 \%$. 
In general, thermosiphon systems are more common in warm climates such as in Africa, South America, southern Europe and the MENA region. In these regions thermosiphon systems are more often equipped with flat plate collectors, while in China, the typical thermosiphon system for domestic hot water preparation is equipped with evacuated tubes.

The calculated number of water-based solar thermal systems in operation was approximately 111 million by the end of 2013 . The breakdown is $6 \%$ used for swimming pool heating, $80 \%$ used for domestic hot water preparation in single family houses, and $9 \%$ attached to larger domestic hot water consumers, such as multi-family houses, hotels, hospitals, schools, etc. Around 3\% of the installed capacity worldwide supplied heat for both domestic hot water and space heating (solar combi-systems). The remaining systems accounted for about $1 \%$ or almost 5 million square meters of solar thermal collectors and delivered heat to district heating networks, industrial processes or thermally driven solar cooling applications.

Compared to the cumulated installed capacity, the share of swimming pool heating was much less for new installations ( $6 \%$ of total capacity and only $3 \%$ of newly installed capacity). To a lesser extent, this is also true for domestic hot water systems in single-family houses ( $80 \%$ of total capacity and $77 \%$ of newly installed capacity). However, in 2013 this is still the most common application for solar thermal systems worldwide. The share of large-scale domestic hot water applications tended to increase ( $9 \%$ of total capacity and $17 \%$ of newly installed capacity) while the share of solar combi-systems remained at a low level of $3 \%$ for both cumulated installations in operation and new installations in 2013.

\section{Development of global solar thermal capacity in operation and energy yields 2000-2014}

Global solar thermal capacity of unglazed and glazed water collectors in operation grew from $62 \mathrm{GW}_{\text {th }}$ (89 million square meters) in 2000 to $406 \mathrm{GW}_{\text {th }}$ (580 million square meters) in 2014. The corresponding annual solar thermal energy yields amounted to 52 TWh in 2000 and to 341 TWh in 2014 (Figure 2).

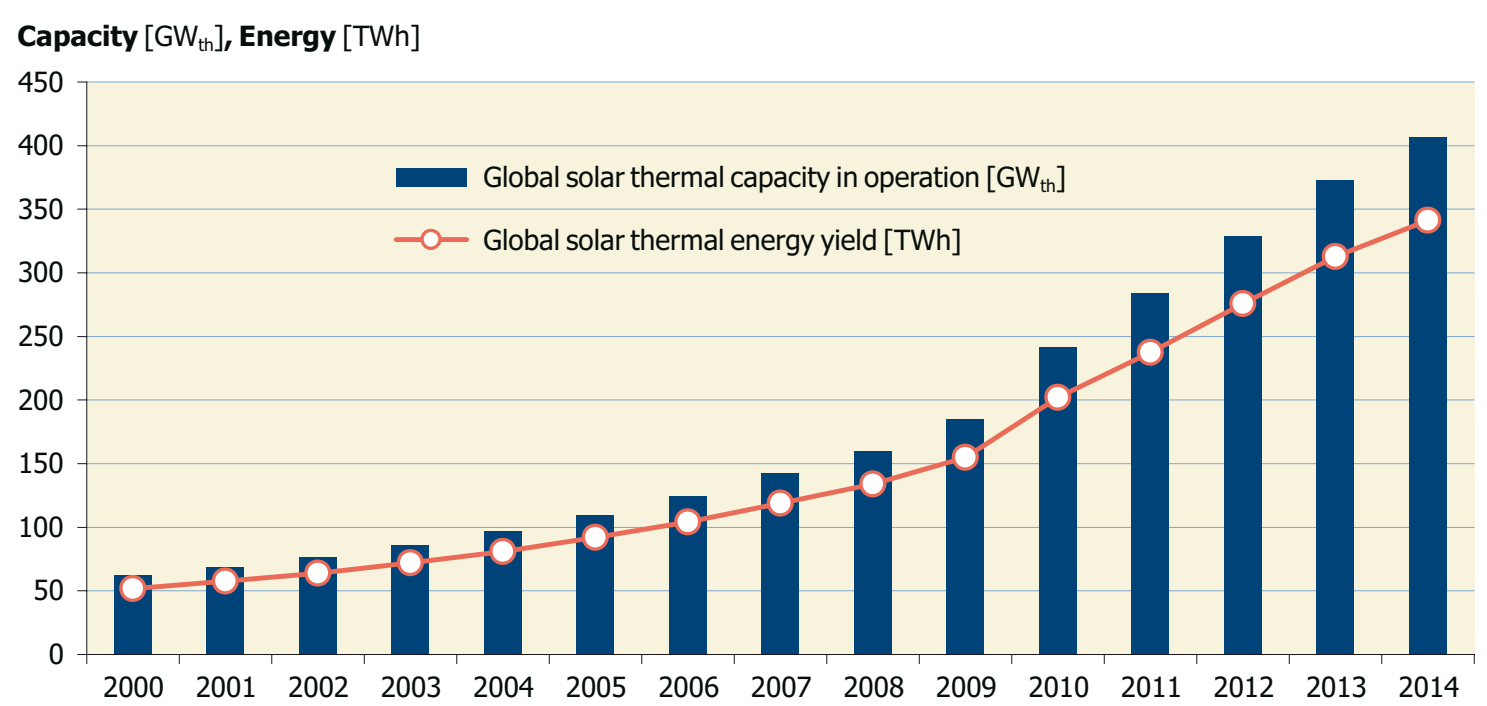

Figure 2: Global solar thermal capacity in operation and annual energy yields 2000-2014 


\subsection{Preview 2014}

The estimated total capacity of solar thermal collectors in operation worldwide by the end of 2014 is $406 \mathrm{GW}_{\text {th, }}$ or 580 million square meters of collector area. This corresponds to an annual collector yield of $341 \mathrm{TWh}$, which is equivalent to savings of 36.7 million tons of oil and 118.6 million tons of $\mathrm{CO}_{2}{ }^{4}$

The preview for 2014 is based on latest market data from Austria, Brazil, China, Germany and India, which represented more than $82 \%$ of the cumulated installed capacity in operation in the year 2013 . The other countries were estimated according to their trend over the past two years.

Compared with other forms of renewable energy, solar heating's contribution in meeting global energy demand is, besides the traditional renewable energies like biomass and hydropower, second only to wind power (Figure 3 ). Considering installed capacity, solar thermal is leading.

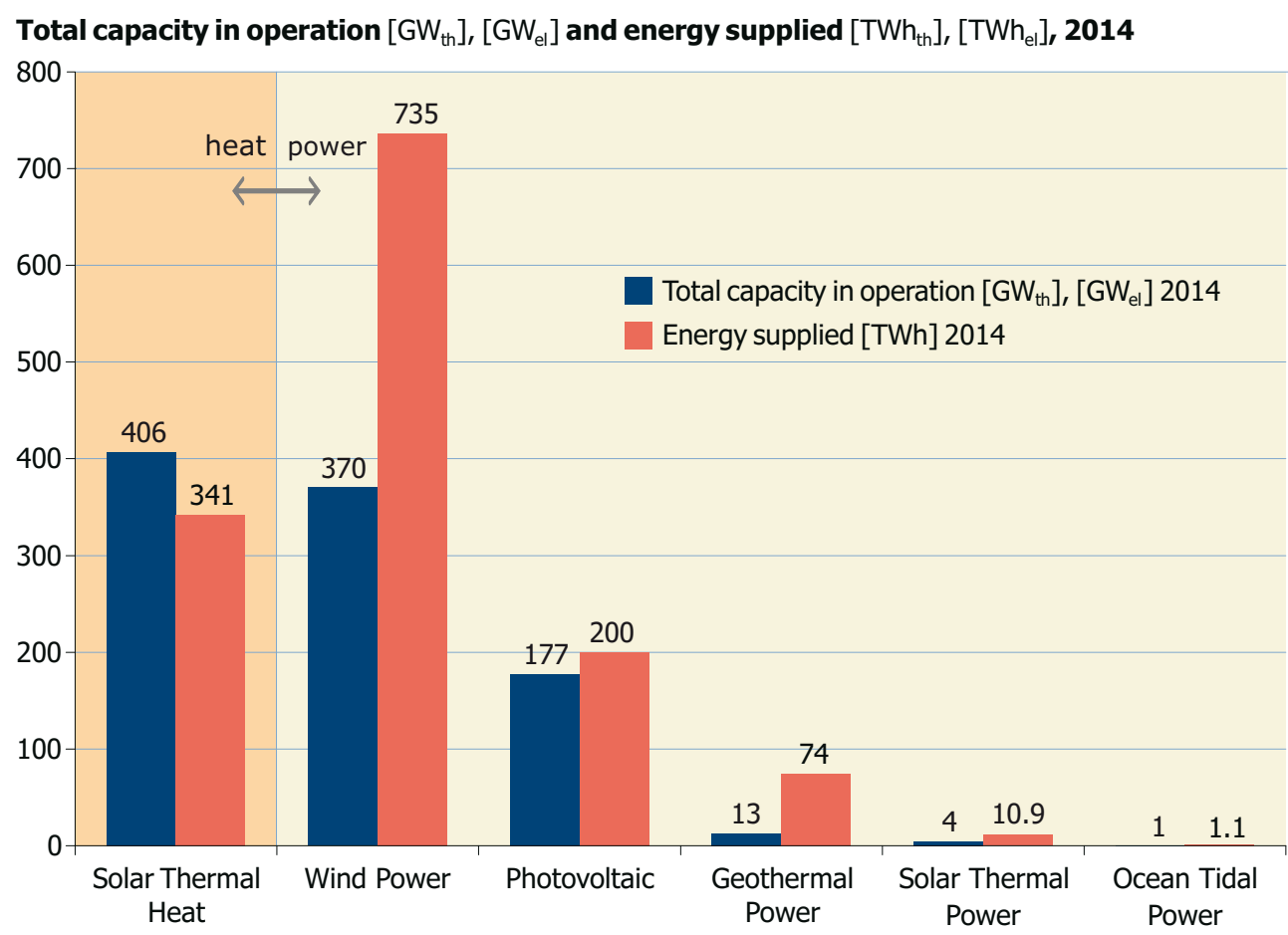

Figure 3: Global capacity in operation [GW $\mathrm{Gl}_{\mathrm{el}},\left[\mathrm{GW}_{\mathrm{th}}\right] 2014$ and annual energy yields [TWhel $\mathrm{TW}_{\mathrm{e}}\left[\mathrm{TWh}_{\mathrm{th}}\right]$ (Sources: AEE INTEC, Global Wind Energy Council (GWEC), European PV Industry Association (EPIA), REN21 - Global Status Reports 2014 and 2015)

Note that, in 2014, the Chinese Solar Thermal Industry Federation (CSTIF) settled on a new methodology for calculating cumulative capacity in operation. Because China is such a large market, this change has a significant effect on the global total. In this edition, the report data have been adjusted accordingly: China's total for 2011 was adjusted upwards to $190 \mathrm{GW}_{\text {th }}$ (from $152 \mathrm{GW}_{\text {th }}$ as reported in previous editions of this report). China's total for 2012 amounted to $226 \mathrm{GW}_{\text {th }}$ (adjusted upwards from $180 \mathrm{GW}_{\text {th) }}$ ) and China's total for 2013 amounted to 262 GW th (adjusted upwards from $217 \mathrm{GW}_{\mathrm{th}}$ ).

Consequently the world totals in operation were revised as well: World 2011 was adjusted upwards to 284 GW th (from 244 GW th, excluding air collectors). World 2012 was adjusted upwards to $329 \mathrm{GW}_{\text {th }}$ (from $281 \mathrm{GW}_{\text {th }}$, excluding air collectors) and World 2013 was adjusted upwards to $373 \mathrm{GW}_{\text {th }}$ (from $325 \mathrm{GW}_{\text {th }}$, excluding air collectors). 
The development of global installed capacity of solar thermal heat, wind and photovoltaic between 2010 and 2014 is shown in Figure 4. It can be highlighted that all mentioned renewable technologies show positive growth rates in terms of cumulated installed capacities, but as a general trend the growth rates tend to flatten out.

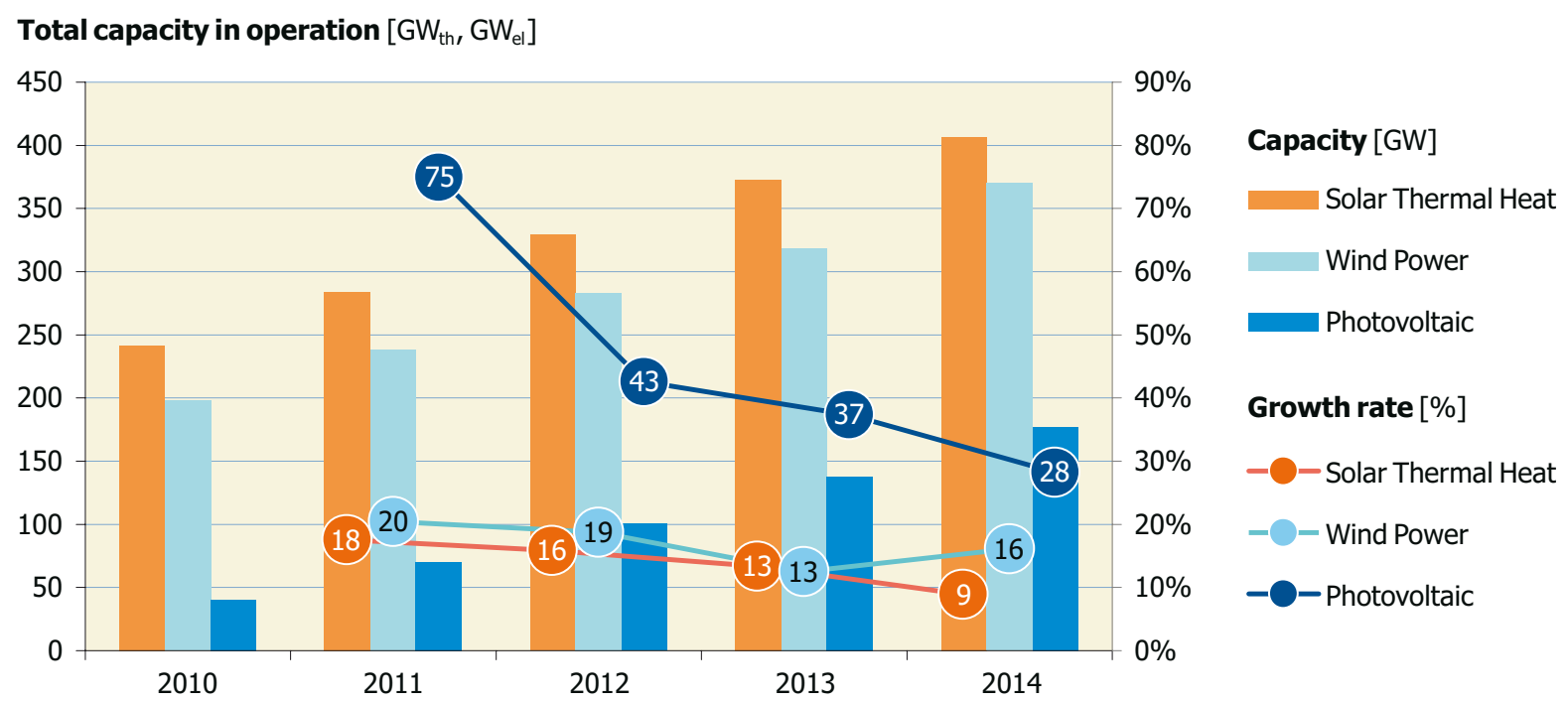

Figure 4: Global solar thermal heat, wind power and photovoltaic capacity in operation and market growth rates between 2010 and 2014

(Sources: AEE INTEC, Global Wind Energy Council (GWEC), European PV Industry Association (EPIA), REN21)

\section{Employment}

Based on data collected from the detailed country reports, the number of jobs in the fields of production, installation and maintenance of solar thermal systems is estimated to be 460,000 worldwide in 2014 . 


\section{Total capacity in operation by end of 2013}

This report aims to give the actual collector area in operation and not the cumulated collector area that has ever been installed in a country. To determine the collector area (and respective capacity) in operation, either official country reports on the lifetime were used or, if such reports were not available, a 25-year lifetime for a system was calculated. The collector area in operation was then calculated using a linear equation. For China, the methodology of the Chinese Solar Thermal Industry Federation (CSTIF) was used. According to the CSTIF approach the operation lifetime is considered to be less than 10 years.

The analysis further aims to distinguish between different types of solar thermal collectors, such as unglazed water collectors, glazed water collectors including flat plate collectors (FPC) and evacuated tube collectors (ETC) as well as unglazed and glazed air collectors.

\subsection{General market overview of the total installed capacity in operation}

By the end of 2013, an installed capacity of $374.7 \mathrm{GW}_{\text {th }}$ corresponding to a total of 535.2 million square meters of collector area was in operation worldwide.

The vast majority of the total capacity in operation was installed in China (262.3 $\mathrm{GW}_{\mathrm{th}}$ ) and Europe (44.1 $\left.\mathrm{GW}_{\mathrm{th}}\right)$, which together accounted for $82 \%$ of the total installed capacity. The remaining installed capacity was shared between the United States and Canada $\left(17.7 \mathrm{GW}_{\text {th }}\right)$, Asia excluding China $\left(10.0 \mathrm{GW}_{\text {th }}\right)$, Latin America $\left(8.7 \mathrm{GW}_{\text {th }}\right)$, the MENA countries Israel, Jordan, Lebanon, Morocco, the Palestinian Territories and Tunisia (6.1 $\mathrm{GW}_{\text {th }}$ ), Australia and New Zealand (5.9 $\mathrm{GW}_{\mathrm{th}}$ ), and Sub-Sahara African countries Mauritius, Mozambique, Namibia, South Africa and Zimbabwe $\left(1.2 \mathrm{GW}_{\text {th }}\right.$ ). The market volume of "all other countries" is estimated to amount for $5 \%$ of the total installations (18.7 $\left.\mathrm{GW}_{\text {th }}\right)$.

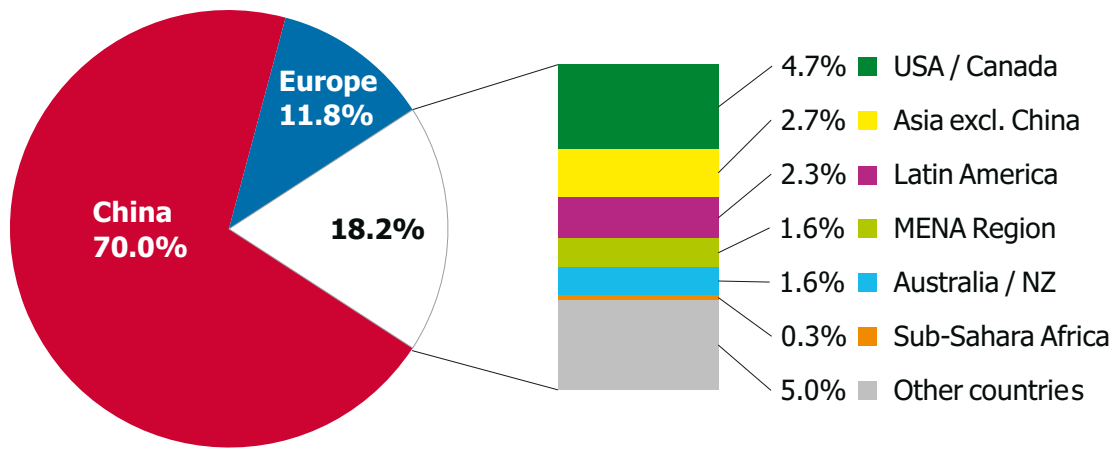

Sub-Sahara Africa: Asia excluding China: Latin America: Europe: MENA Region:
Mauritius, Mozambique, Namibia, South Africa, Zimbabwe India, Japan, Korea South, Taiwan, Thailand Barbados, Brazil, Chile, Mexico, Uruguay

EU 28, Albania, Macedonia, Norway, Russia, Switzerland, Turkey Israel, Jordan, Lebanon, Morocco, Palestinian Territories, Tunisia

Figure 5: Share of the total installed capacity in operation (glazed and unglazed water and air collectors) by economic region at the end of 2013 


\begin{tabular}{|c|c|c|c|c|c|c|}
\hline \multirow{2}{*}{ Country } & \multicolumn{3}{|c|}{ Water Collectors $\left[\mathrm{MW}_{\text {th }}\right]$} & \multicolumn{2}{|c|}{ Air Collectors $\left[\mathrm{MW}_{\text {th }}\right]$} & \multirow{2}{*}{ TOTAL $\left[\mathrm{MW}_{\mathrm{th}}\right]$} \\
\hline & unglazed & FPC & ETC & unglazed & glazed & \\
\hline Albania & & 98.6 & 0.7 & & & 99 \\
\hline Australia & $3,346.0$ & $2,201.5$ & 68.6 & 210.0 & 5.5 & 5,832 \\
\hline Austria & 372.2 & $3,109.4$ & 57.7 & & 2.0 & 3,541 \\
\hline Barbados* & & 92.2 & & & & 92 \\
\hline Belgium & 31.5 & 264.1 & 45.8 & & & 341 \\
\hline Brazil & $2,055.4$ & $4,664.1$ & 6.9 & & & 6,726 \\
\hline Bulgaria & & 86.6 & 1.8 & & & 88 \\
\hline Canada & 550.1 & 44.9 & 27.5 & 261.2 & 20.8 & 905 \\
\hline Chile & & 97.5 & & & & 98 \\
\hline China & & $19,437.3$ & $242,824.7$ & & & 262,262 \\
\hline Croatia & & 100.1 & 1.8 & & & 102 \\
\hline Cyprus & 1.5 & 472.6 & 16.5 & & & 491 \\
\hline Czech Republic & 352.1 & 257.7 & 70.1 & & & 680 \\
\hline Denmark & 14.4 & 528.8 & 6.4 & 2.3 & 12.6 & 564 \\
\hline Estonia & & 3.5 & 2.5 & & & 6 \\
\hline Finland & 8.2 & 23.1 & 5.2 & & & 37 \\
\hline France (mainland) + & 74.0 & $1,542.0$ & 43.3 & 3.5 & 0.8 & 1,664 \\
\hline Germany & 393.5 & $10,538.5$ & $1,327.9$ & & 20.6 & 12,281 \\
\hline Greece & & $2,912.1$ & 12.8 & & & 2,925 \\
\hline Hungary & 10.0 & 125.4 & 41.0 & 1.4 & 1.2 & 179 \\
\hline India ++ & & $2,277.1$ & $2,084.7$ & & 5.7 & 4,368 \\
\hline Ireland & & 130.2 & 64.2 & & & 194 \\
\hline Israel & 24.2 & $2,880.4$ & 0.4 & 0.4 & & 2,905 \\
\hline Italy & 30.6 & $2,200.9$ & 353.5 & & & 2,585 \\
\hline Japan & & $2,797.6$ & 54.4 & & 358.6 & 3,211 \\
\hline Jordan $* * * *$ & 4.2 & 649.6 & 180.9 & & & 835 \\
\hline Korea, South & & $1,233.8$ & & & & 1,234 \\
\hline Latvia & & 3.0 & 1.2 & & & 4 \\
\hline Lebanon & & 172.2 & 220.5 & & & 393 \\
\hline Lithuania & & 2.9 & 2.9 & & & 6 \\
\hline Luxembourg & & 28.0 & 4.0 & & & 32 \\
\hline Macedonia & & 28.3 & 4.7 & & & 33 \\
\hline Malta & & 27.1 & 6.8 & & & 34 \\
\hline Mauritius \# & & 80.6 & & & & 81 \\
\hline Mexico & 598.7 & 659.7 & 489.5 & 0.5 & 6.1 & 1,755 \\
\hline Morocco & & 290.5 & & & & 291 \\
\hline Mozambique & & & 0.3 & & & 0 \\
\hline Namibia*** & & 14.5 & 0.9 & & & 15 \\
\hline Netherlands & 296.8 & 307.1 & 12.4 & & & 616 \\
\hline New Zealand* & 4.9 & 100.1 & 6.8 & & & 112 \\
\hline Norway & 1.3 & 24.0 & 2.4 & & 2.8 & 31 \\
\hline Palestinian Territories \# & & $1,134.0$ & 4.9 & & & 1,139 \\
\hline Poland & & 774.5 & 265.0 & & & 1,040 \\
\hline Portugal & 1.5 & 614.3 & 17.5 & & & 633 \\
\hline Romania & & 60.0 & 30.0 & 0.6 & & 91 \\
\hline Russia & & 11.7 & 1.0 & & & 13 \\
\hline Slovakia & & 91.0 & 14.2 & & & 105 \\
\hline Slovenia & & 115.9 & 14.9 & & & 131 \\
\hline South Africa & 641.8 & 303.1 & 109.7 & & & 1,055 \\
\hline Spain & 96.6 & $2,018.7$ & 121.5 & & & 2,237 \\
\hline Sweden & 91.0 & 183.4 & 43.4 & & & 318 \\
\hline Switzerland & 148.2 & 760.0 & 61.2 & 560.0 & & 1,529 \\
\hline Taiwan & 1.0 & $1,025.7$ & 55.2 & & & 1,082 \\
\hline Thailand & & 95.6 & & & & 96 \\
\hline Tunisia & & 445.4 & 49.1 & & & 494 \\
\hline Turkey & & $9,114.6$ & $1,854.7$ & 1.4 & & 10,971 \\
\hline United Kingdom & & 395.5 & 125.2 & 14.0 & & 535 \\
\hline United States & $14,635.1$ & $1,964.7$ & 90.2 & 72.2 & 19.5 & 16,782 \\
\hline Uruguay** & & 8.8 & & & & 9 \\
\hline Zimbabwe & & 14.5 & 1.6 & & & 16 \\
\hline All other countries \# & 1,252 & 4,192 & 13,206 & 59 & 24 & 18,733 \\
\hline TOTAL & 25,037 & 83,831 & 264,117 & 1,187 & 481 & 374,651 \\
\hline
\end{tabular}

Note: If no data is given: no reliable database for this collector type is available

* Total capacity in operation refers to the year $2009 \quad * * \quad$ Total capacity in operation refers to the year 2011

*** Total capacity in operation refers to the year $2012 \quad * * * *$ Total capacity in operation is based on estimations for new installations in 2013

\# $\quad$ Newly included countries compared to the 2014 edition of this report

$+\quad$ The figures for France relate to Metropolitan France (mainland) only. Overseas Departments were not taken into account in this years statistics.

$++\quad$ The figures for India refer to fiscal year end (April 2013-March 2014)

Table 1: Total capacity in operation by the end of 2013 [ $\left.\mathrm{MW}_{\mathrm{th}}\right]$ 


\begin{tabular}{|c|c|c|c|c|c|c|}
\hline \multirow{2}{*}{ Country } & \multicolumn{3}{|c|}{ Water Collectors [ $\mathrm{m}^{2}$ ] } & \multicolumn{2}{|c|}{ Air Collectors $\left[\mathrm{m}^{2}\right]$} & \multirow{2}{*}{ TOTAL [m²] } \\
\hline & unglazed & FPC & ETC & unglazed & glazed & \\
\hline Albania & & 140,815 & 1,070 & & & 141,885 \\
\hline Australia & $4,780,000$ & $3,145,000$ & 98,000 & 300,000 & 7,840 & $8,330,840$ \\
\hline Austria & 531,691 & $4,442,045$ & 82,362 & & 2,918 & $5,059,016$ \\
\hline Barbados* & & 131,690 & & & & 291,690 \\
\hline Belgium & 45,000 & 377,330 & 65,453 & & & 487,783 \\
\hline Brazil & $2,936,351$ & $6,663,003$ & 9,909 & & & $9,609,263$ \\
\hline Bulgaria & & 123,680 & 2,520 & & & 126,200 \\
\hline Canada & 785,857 & 64,210 & 39,303 & 373,154 & 29,724 & $1,292,248$ \\
\hline Chile & & 139,309 & & & & 139,309 \\
\hline China & & $27,767,614$ & $346,892,386$ & & & $374,660,000$ \\
\hline Croatia & & 143,065 & 2,500 & & & 145,565 \\
\hline Cyprus & 2,180 & 675,200 & 23,567 & & & 700,947 \\
\hline Czech Republic & 503,000 & 368,119 & 100,150 & & & 971,269 \\
\hline Denmark & 20,515 & 755,378 & 9,197 & 3,264 & 18,000 & 806,354 \\
\hline Estonia & & 4,930 & 3,590 & & & 8,520 \\
\hline Finland & 11,779 & 33,051 & 7,372 & & & 52,202 \\
\hline France (mainland) + & 105,699 & $2,202,904$ & 61,796 & 5,053 & 1,117 & $2,376,569$ \\
\hline Germany & 562,176 & $15,055,000$ & $1,897,000$ & & 29,491 & $17,543,667$ \\
\hline Greece & & $4,160,100$ & 18,250 & & & $4,178,350$ \\
\hline Hungary & 14,300 & 179,200 & 58,600 & 2,000 & 1,650 & 255,750 \\
\hline India ++ & & $3,253,010$ & $2,978,190$ & & 8,200 & $6,239,400$ \\
\hline Ireland & & 185,952 & 91,667 & & & 277,619 \\
\hline Israel & 34,617 & $4,114,876$ & 622 & 550 & & $4,150,665$ \\
\hline Italy & 43,766 & $3,144,110$ & 505,020 & & & $3,692,896$ \\
\hline Japan & & $3,996,621$ & 77,775 & & 512,219 & $4,586,615$ \\
\hline Jordan**** & 5,940 & 927,951 & 258,379 & & & $1,192,270$ \\
\hline Korea, South & & $1,762,570$ & & & & $1,762,570$ \\
\hline Latvia & & 4,350 & 1,690 & & & 6,040 \\
\hline Lebanon & & 246,000 & 315,000 & & & 561,000 \\
\hline Lithuania & & 4,100 & 4,100 & & & 8,200 \\
\hline Luxembourg & & 40,050 & 5,750 & & & 45,800 \\
\hline Macedonia & & 40,380 & 6,750 & & & 47,130 \\
\hline Malta & & 38,758 & 9,690 & & & 48,448 \\
\hline Mauritius \# & & 115,113 & & & & 115,113 \\
\hline Mexico & 855,253 & 942,482 & 699,342 & 752 & 8,773 & $2,506,602$ \\
\hline Morocco & & 415,000 & & & & 415,000 \\
\hline Mozambique & & & 416 & & & 416 \\
\hline Namibia*** & & 20,699 & 1,307 & & & 22,006 \\
\hline Netherlands & 424,052 & 438,702 & 17,696 & & & 880,450 \\
\hline New Zealand* & 7,025 & 142,975 & 9,644 & & & 159,645 \\
\hline Norway & 1,926 & 34,236 & 3,414 & & 4,067 & 43,643 \\
\hline Palestinian Territories \# & & $1,620,000$ & 7,000 & & & $1,627,000$ \\
\hline Poland & & $1,106,400$ & 378,600 & & & $1,485,000$ \\
\hline Portugal & 2,128 & 877,551 & 24,950 & & & 904,629 \\
\hline Romania & & 85,700 & 42,850 & 800 & & 129,350 \\
\hline Russia & & 16,756 & 1,457 & & & 18,213 \\
\hline Slovakia & & 129,950 & 20,250 & & & 150,200 \\
\hline Slovenia & & 165,550 & 21,250 & & & 186,800 \\
\hline South Africa & 916,881 & 432,946 & 156,784 & & & $1,506,611$ \\
\hline Spain & 137,985 & $2,883,812$ & 173,542 & & & $3,195,339$ \\
\hline Sweden & 130,000 & 262,000 & 62,000 & & & 454,000 \\
\hline Switzerland & 211,740 & $1,085,760$ & 87,440 & 800,000 & & $2,184,940$ \\
\hline Taiwan & 1,394 & $1,465,311$ & 78,924 & & & $1,545,628$ \\
\hline Thailand & & 136,611 & & & & 136,611 \\
\hline Tunisia & & 636,276 & 70,104 & & & 706,380 \\
\hline Turkey & & $13,020,812$ & $2,649,509$ & 2,070 & & $15,672,391$ \\
\hline United Kingdom & & 565,025 & 178,848 & 20,000 & & 763,873 \\
\hline United States & $20,907,216$ & $2,806,716$ & 128,832 & 103,139 & 27,800 & $23,973,703$ \\
\hline Uruguay** & & 12,571 & & & & 12,571 \\
\hline Zimbabwe & & 20,756 & 2,222 & & & 22,978 \\
\hline All other countries \# & $1,788,341$ & $5,987,899$ & $18,865,476$ & 84,778 & 34,305 & $26,760,799$ \\
\hline TOTAL & $35,766,811$ & $119,757,981$ & $377,309,514$ & $1,695,560$ & 686,105 & $535,215,971$ \\
\hline
\end{tabular}

Note: If no data is given: no reliable database for this collector type is available

* Total capacity in operation refers to the year $2009 \quad * * \quad$ Total capacity in operation refers to the year 2011

*** Total capacity in operation refers to the year $2012 \quad * * * *$ Total capacity in operation is based on estimations for new installations in 2013

\# Newly included countries compared to the 2014 edition of this report

$+\quad$ The figures for France relate to Metropolitan France (mainland) only. Overseas Departments were not taken into account in this years statistics.

$++\quad$ The figures for India refer to fiscal year end (April 2013-March 2014)

Table 2: Total installed collector area in operation by the end of 2013 [ $\left.\mathrm{m}^{2}\right]$ 
The total installed capacity in operation by end of 2013 is divided into flat plate collectors (FPC): 83.9 GW th $_{\text {(119.9 }}$ million square meters), evacuated tube collectors (ETC): $264.1 \mathrm{GW}_{\text {th }}$ (377.3 million square meters), unglazed water collectors $25.0 \mathrm{GW}_{\text {th }}$ (35.7 million square meters), and glazed and unglazed air collectors: $1.7 \mathrm{GW}_{\text {th }}(2.4 \mathrm{million}$ square meters).

With a share of $70.5 \%$, evacuated tube collectors are the predominant solar thermal collector technology worldwide, followed by flat plate collectors with $22.4 \%$ and unglazed water collectors with $6.7 \%$. Air collectors only play a minor role in total numbers (Figure 6).

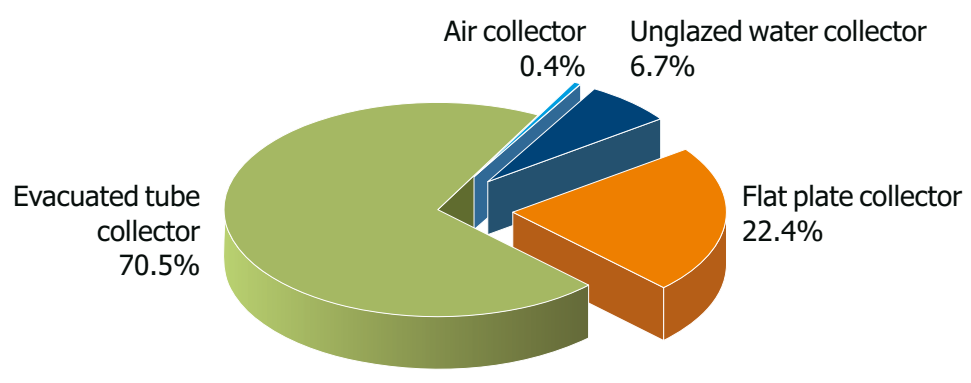

Figure 6: Distribution of the total installed capacity in operation by collector type in 2013 - WORLD

By contrast in Europe, the second largest marketplace for solar thermal collectors to China, flat plate collectors are much more widespread (Figure 7).

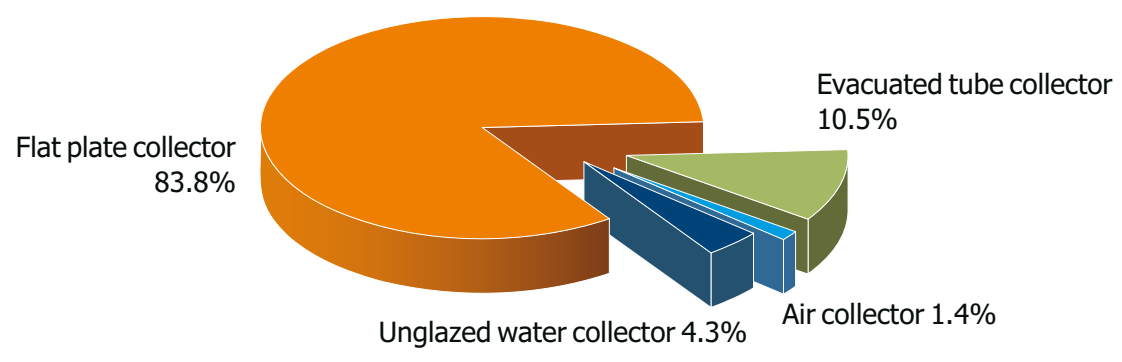

Figure 7: Distribution of the total installed capacity in operation by collector type in 2013 - EUROPE 
Figure 8 shows the cumulated installed capacity of glazed and unglazed water collectors in operation for the 10 leading markets in 2013 in total numbers.

262,262

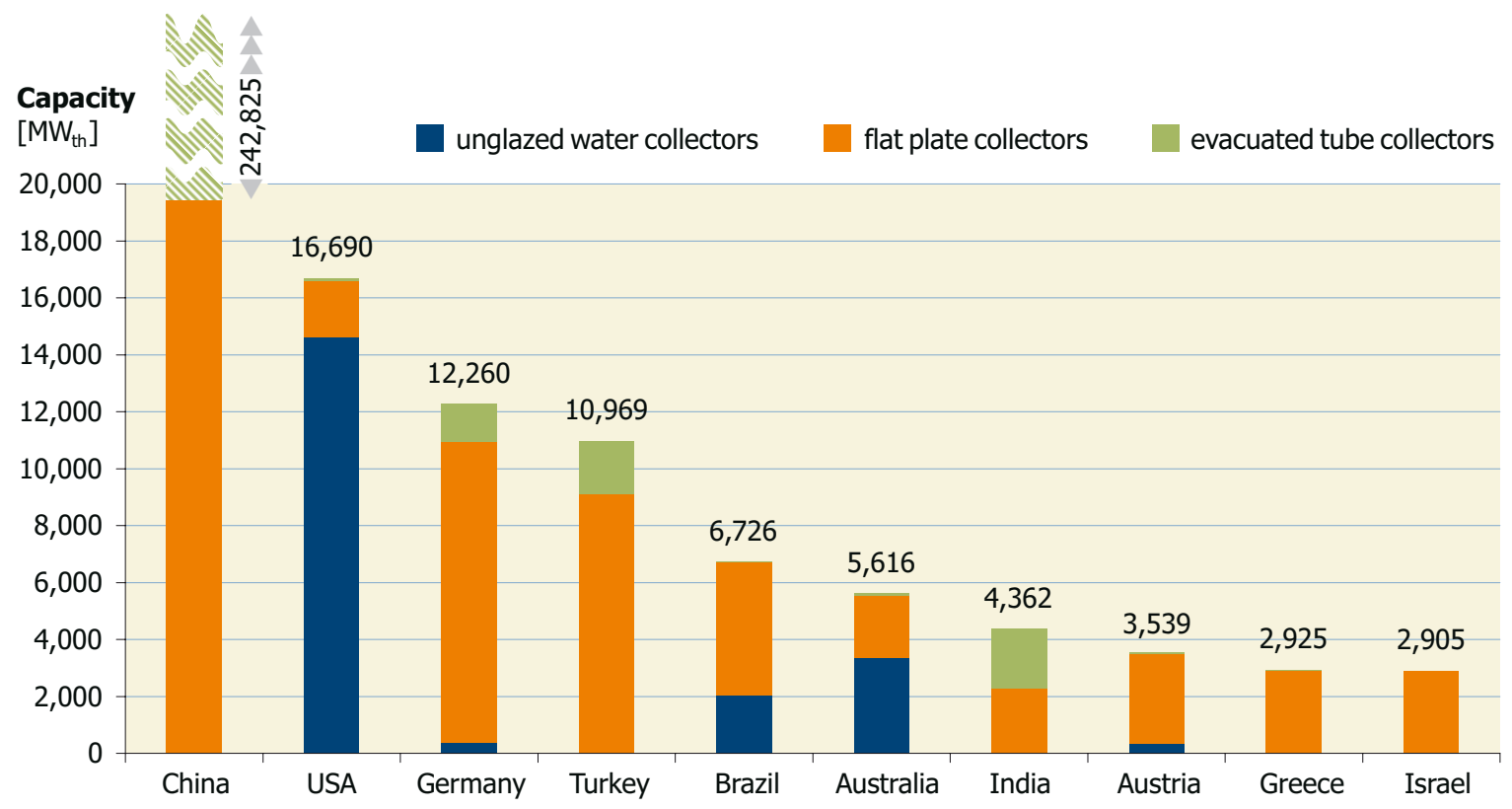

Figure 8: Top 10 countries of cumulated water collector installations (absolute figures in $\mathrm{MW}_{\text {th }}$ )

China, as the world leader in total capacity, is focusing very much on evacuated tube collectors, whereas the United States is holding second position due to its high installation of unglazed water collectors. Only in Australia, and to some extent in Brazil, unglazed water collectors also play an important role. The rest of the "Top 10 countries" are clearly focusing on flat plate collector technology.

The leading countries in cumulated unglazed and glazed water collector capacity in operation in 2013 per 1,000 inhabitants were Austria (430 kW th $/ 1,000$ inhabitants), Cyprus (425 kW th/1,000 inhabitants), Israel (377 kW th/1,000 inhabitants), Barbados (319 kW th/1,000 inhabitants), Greece (271 kW th/1,000 inhabitants), the Palestinian Territories (257 kW th/1,000 inhabitants), Australia (252 kW th/1,000 inhabitants), China (194 kW th 1 ,000 inhabitants), Germany (151 kW th/1,000 inhabitants) and Turkey (136 kW $\mathrm{th} / 1,000$ inhabitants).

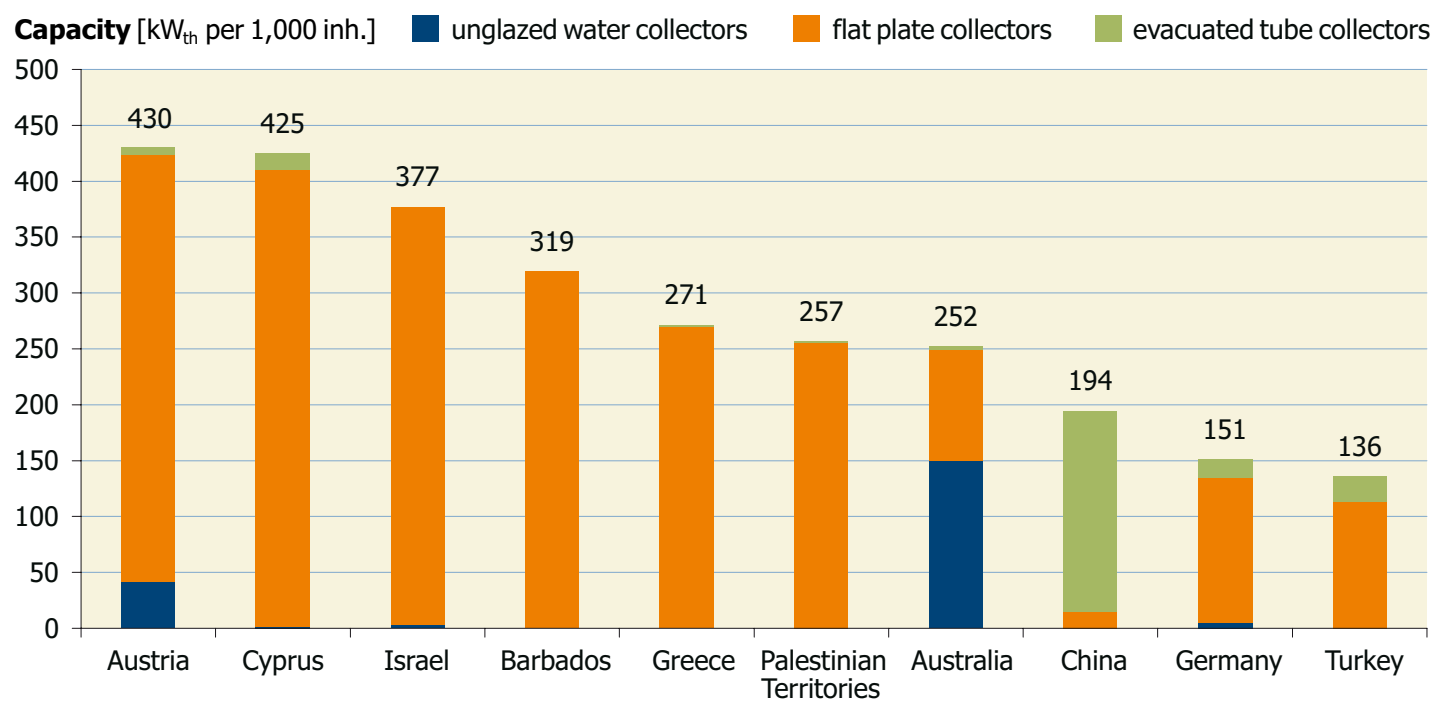

Figure 9: Top 10 countries of cumulated water collector installations (relative figures in $\mathrm{kW}_{\text {th }}$ per 1,000 inhabitants) 


\subsection{Total capacity of glazed water collectors in operation}

With $262.3 \mathrm{GW}_{\text {th }}$, China was by far the leader in terms of total installed capacity of glazed water collectors in 2013. With $>10 \mathrm{GW}_{\text {th }}$ of installed capacity, Germany and Turkey were next. Several countries, namely Brazil, India, Austria, Greece, Israel, Japan, Italy, Australia, Spain, the United States, France, South Korea, Mexico, the Palestinian Territories, Taiwan and Poland had more than $1 \mathrm{GW}_{\text {th }}$ of water collectors installed by the end of 2013 (Figure 10).

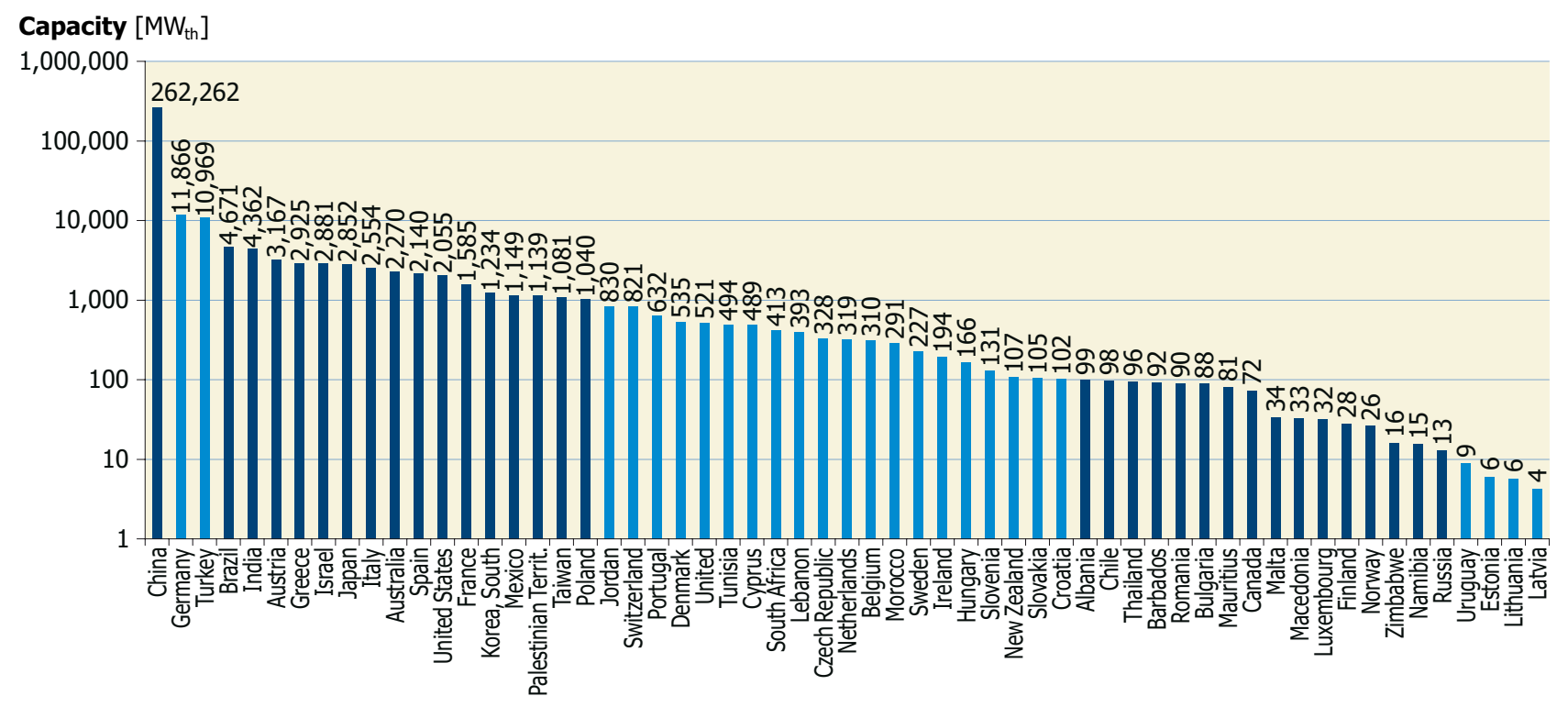

Figure 10: Total capacity of glazed water collectors in operation by the end of 2013

In terms of total installed capacity of glazed water collectors in operation per 1,000 inhabitants, there was a continued dominance by five countries: Cyprus ahead of Austria, Israel, Barbados and Greece. In 2013, China was catching up with the Top 10 countries and exceeded the per capita levels of the large European markets of Germany and Turkey for the first time (Figure 11).

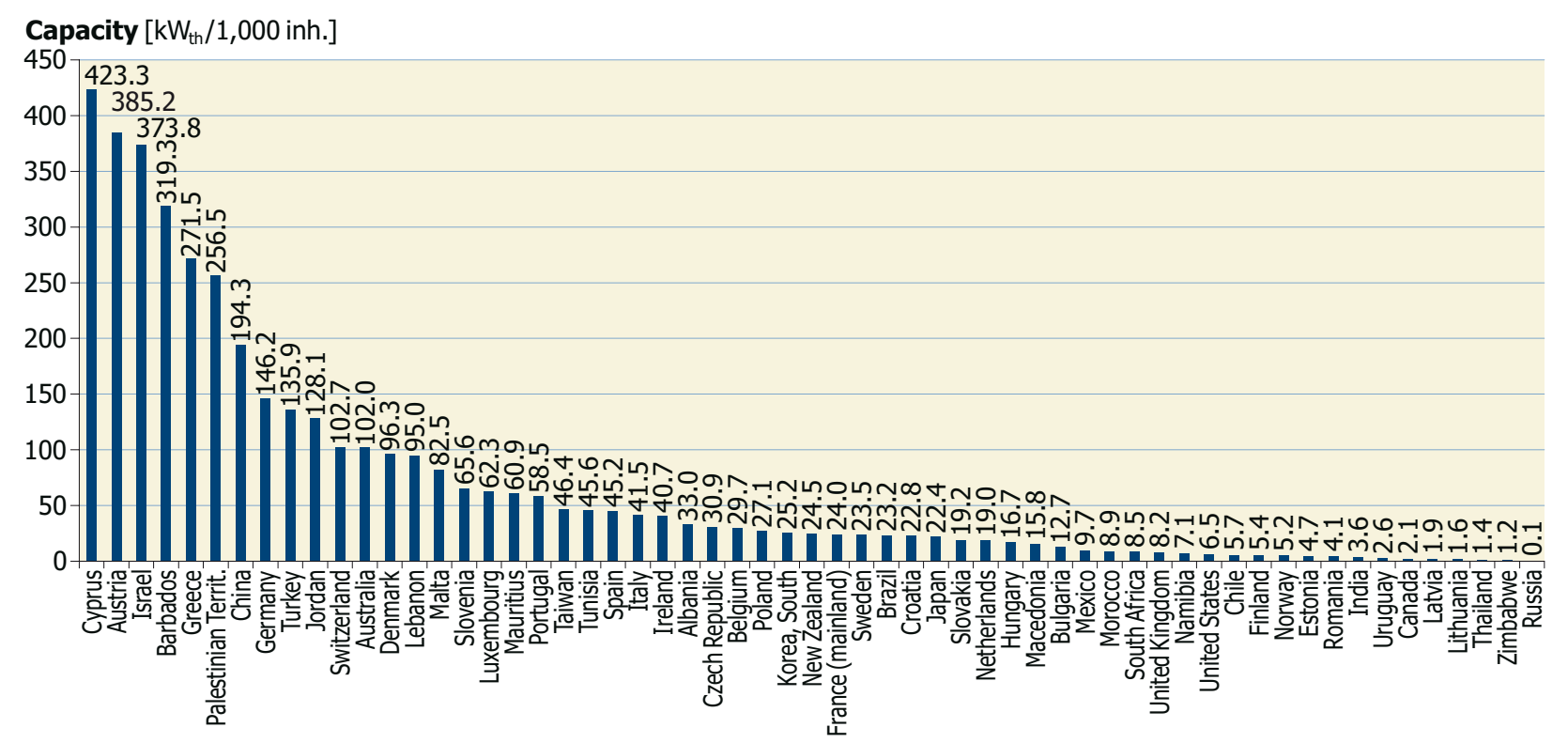

Figure 11: Total capacity of glazed water collectors in operation in $\mathrm{kW}_{\text {th }}$ per 1,000 inhabitants by the end of 2013 


\subsection{Total capacity of glazed water collectors in operation by economic region}

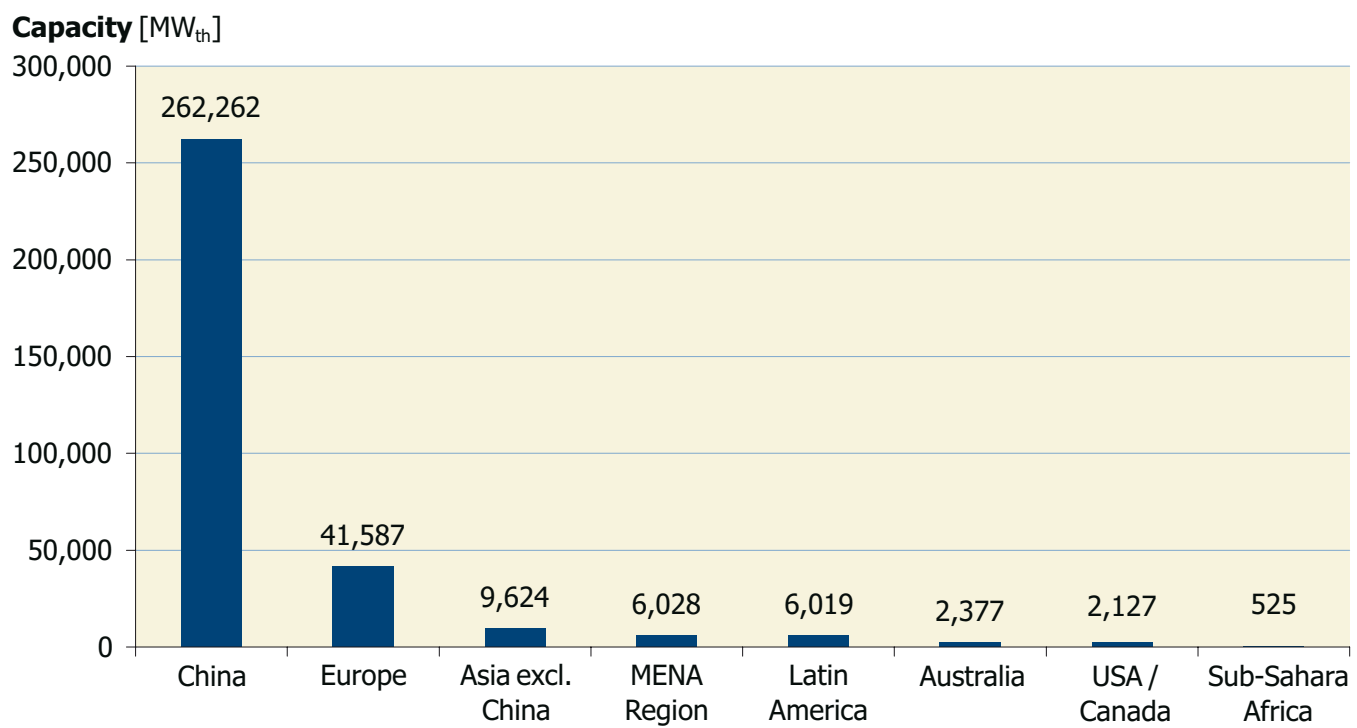

Figure 12: Total capacity of glazed flat plate and evacuated tube collectors in operation by economic region at the end of 2013

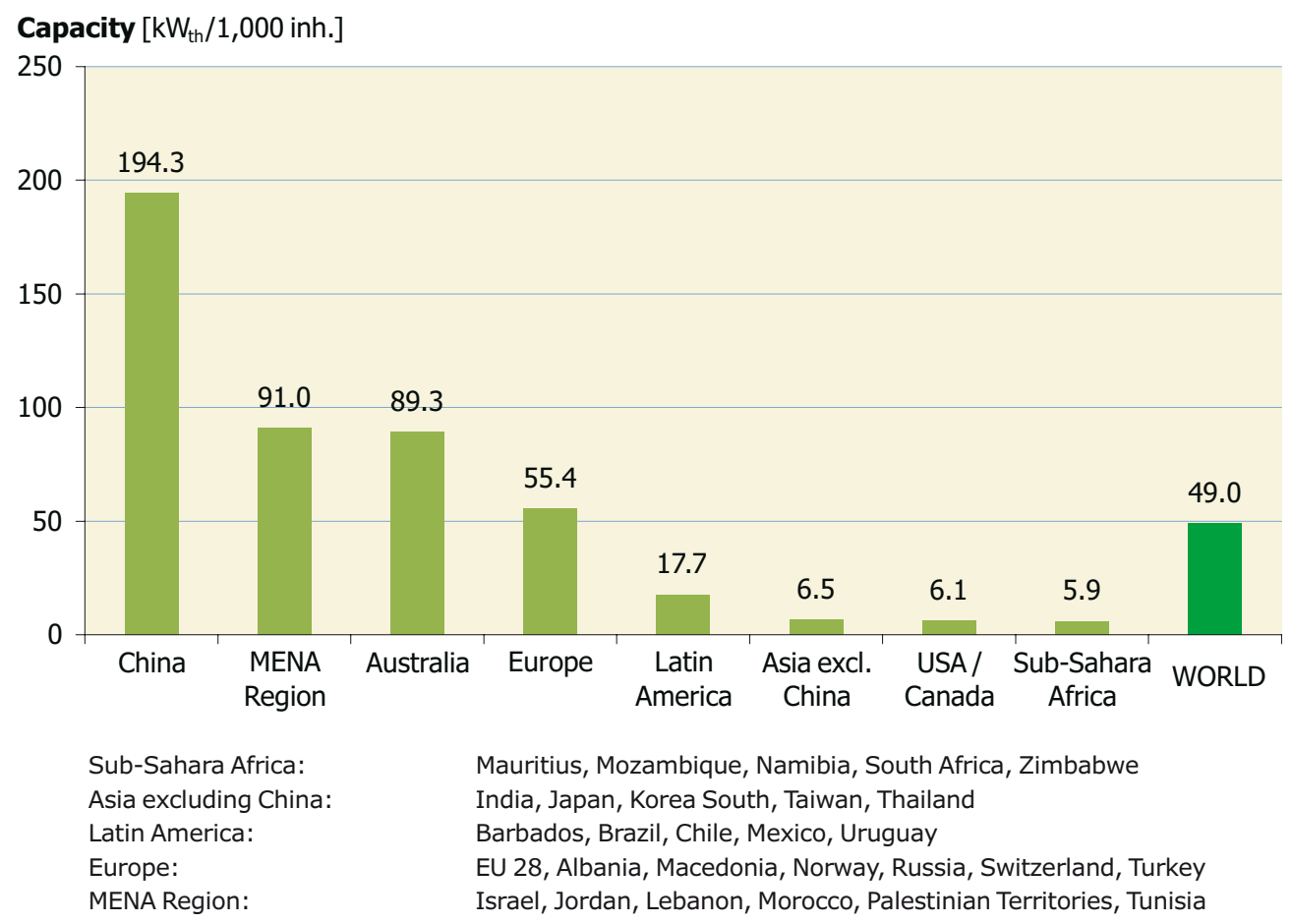

Figure 13: Total capacity of glazed flat plate and evacuated tube collectors in operation by economic region and in $\mathrm{kW}_{\text {th }}$ per 1,000 inhabitants by the end of 2013 


\subsection{Total capacity of unglazed water collectors in operation}

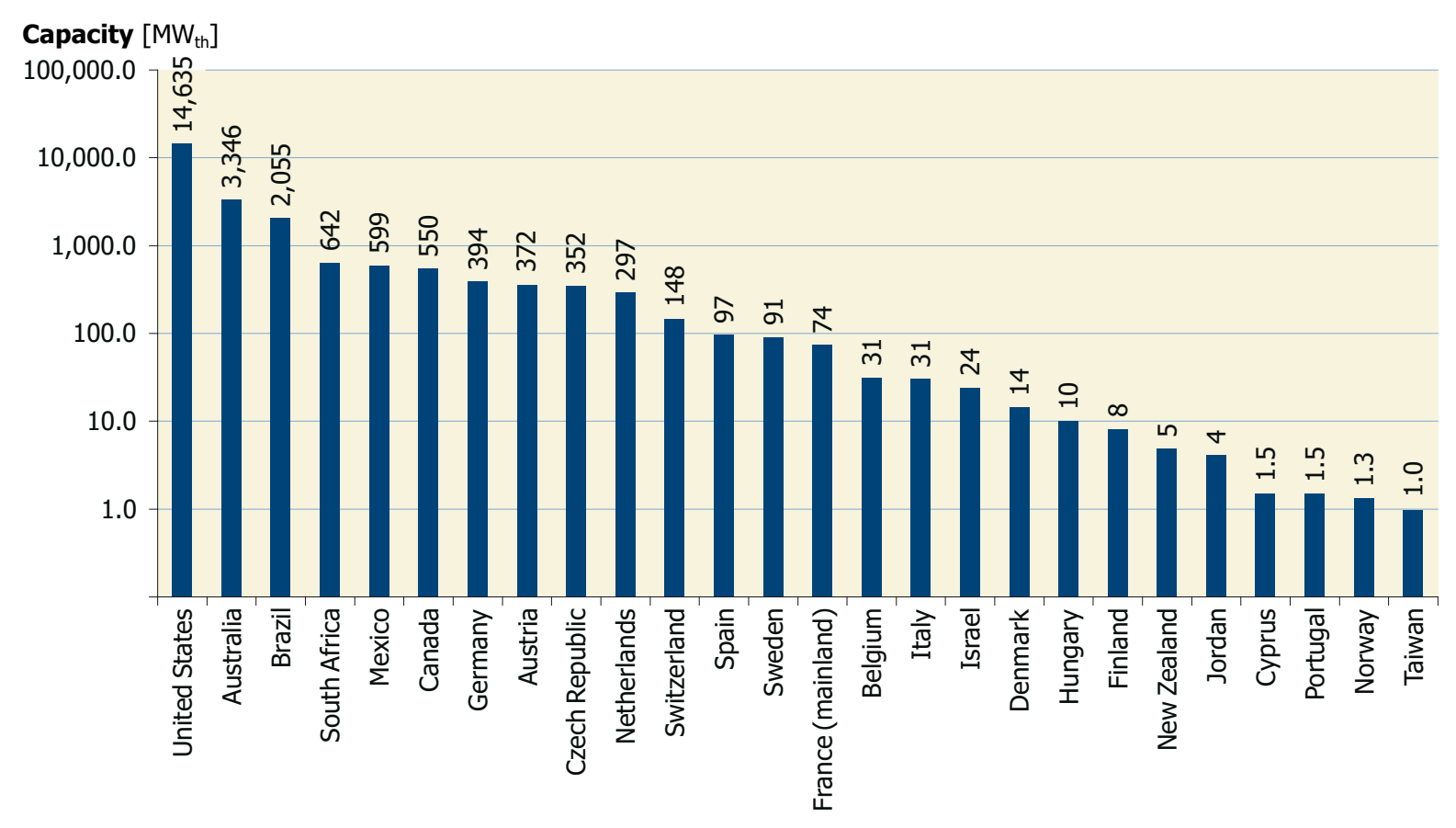

Figure 14: Total capacity of unglazed water collectors in operation by the end of 2013

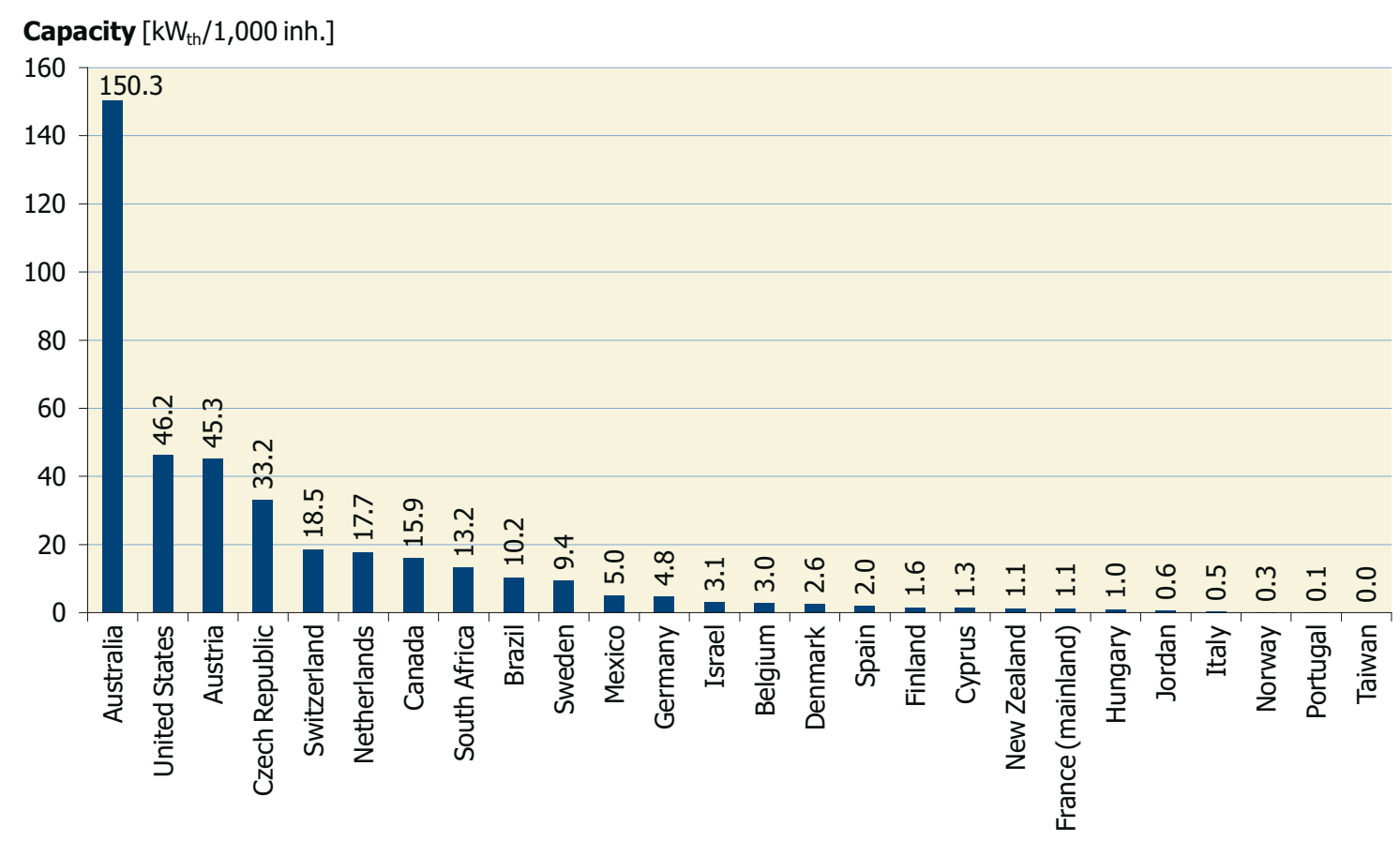

Figure 15: Total capacity of unglazed water collectors in operation in $\mathrm{kW}_{\text {th }}$ per 1,000 inhabitants by the end of 2013 


\section{Newly installed capacity in 2013 and market development}

\subsection{General market overview of newly installed capacity}

In the year 2013, a total capacity of $55.0 \mathrm{GW}_{\text {th }}$, corresponding to 78.6 million square meters of solar collectors, was installed worldwide. This means an increase in new collector installations of 1.8\% compared to the year 2012 (Figure 17). Compared to the previous years, the global market growth rate $2012 / 2013$ tended to flatten out-the market growth in the period $2011 / 2012$ amounted to $6.6 \%$ and in the period $2010 / 2011$ to $14.3 \%$.

The main markets were in China ( $44.5 \mathrm{GW}_{\text {th }}$ ) and Europe (3.6 GW $\mathrm{Gh}_{\text {th }}$ ), which together accounted for $87 \%$ of the overall new collector installations in 2013. The rest of the market was shared between Latin America (1.2 GW $\mathrm{Wh}_{\text {th }}$, Asia excluding China $\left(1.0 \mathrm{GW}_{\mathrm{th}}\right)$, the United States and Canada $\left(0.8 \mathrm{GW}_{\mathrm{th}}\right)$, Australia $\left(0.6 \mathrm{GW}_{\mathrm{th}}\right)$, the MENA region represented by Israel, Jordan, Lebanon, Morocco, the Palestinian Territories and Tunisia $\left(0.5 \mathrm{GW}_{\text {th }}\right)$ and the Sub-Sahara African countries Mozambique, South Africa and Zimbabwe $\left(0.1 \mathrm{GW}_{\mathrm{th}}\right)$. The market volume of "all other countries" is estimated to amount for $5 \%$ of the new installations ( $\left.2.8 \mathrm{GW}_{\text {th }}\right)$.

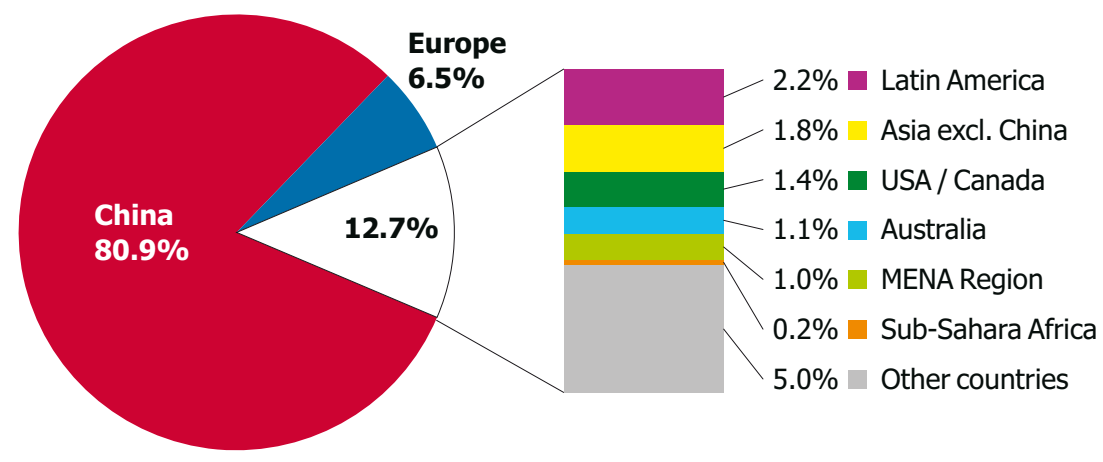

$$
\begin{array}{ll}
\text { Sub-Sahara Africa: } & \text { Mauritius, Mozambique, South Africa, Zimbabwe } \\
\text { Asia excluding China: } & \text { India, Japan, Korea South, Taiwan, Thailand } \\
\text { Latin America: } & \text { Brazil, Chile, Mexico } \\
\text { Europe: } & \text { EU 28, Albania, Macedonia, Norway, Russia, Switzerland, Turkey } \\
\text { MENA Region: } & \text { Israel, Jordan, Lebanon, Morocco, Palestinian Territories, Tunisia }
\end{array}
$$

Figure 16: Share of newly installed capacity (glazed and unglazed water and air collectors)

by economic regions in 2013

From the top 10 markets in 2013 positive market development was reported from China $(+2.5 \%)$, Turkey $(18.2 \%)$, Brazil $(+19.8 \%)$ and Israel $(+35.8 \%)$. The other major solar thermal markets within the top 10, namely India $(-22.9 \%)$, the United States $(-0.2 \%)$, Germany $(-11.3 \%)$, Australia $(-8.8 \%)$, Italy $(-10.0 \%)$ and Poland $(-9.2 \%)$ suffered market declines.

In terms of economic regions, there was positive market growth in the period 2012/2013 in China, Latin America, the MENA region and Sub-Sahara Africa whereas in Europe, Asia excl. China, the United States and Canada and Australia solar thermal system installations dropped (Figure 17). 


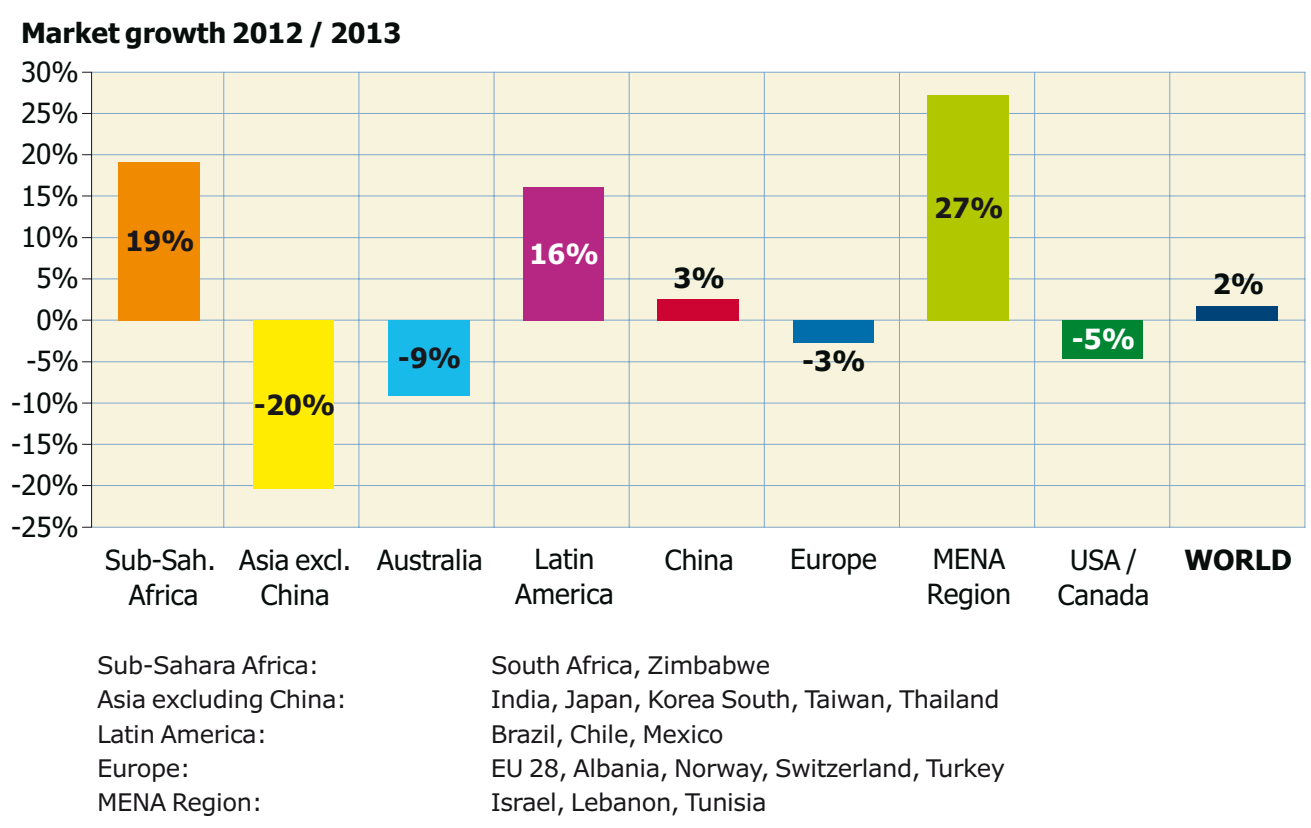

Figure 17: Market growth of newly installed capacity (glazed and unglazed water collectors) 2012/2013 by economic region and world-wide

In China, the growth rates between 2000 and 2011 were on average around $23 \%$ and since then have been leveling off ( $+17.6 \%$ in $2010 / 2011,+7.6 \%$ in $2011 / 2012,+2.6 \%$ in $2012 / 2013)$. For the period $2013 / 2014$ even a market decline of $-17.6 \%$ was reported from the Chinese Solar thermal industry federation (CSTIF), which means the first negative growth rate in China since official recordings are available (1997).

Almost all of the other Asian countries, excluding China, covered in this report already showed a market decline in the period 2012/2013: India (-22.9\%), Japan (-9.0\%), South Korea (-24.0\%) and Thailand (-28.3\%). Only from Taiwan a slight increase of $+2.8 \%$ was reported.

Major European markets such as Austria, Germany and Italy have been suffering from significant market declines for several years now. In the period 2012/2013 only two countries of the top 10 European countries, namely Turkey $(+18.2 \%)$ and Spain $(+2.3 \%)$, reported a positive growth rate. A decrease of $-2.8 \%$ was reported for all of Europe

In Latin America the large Brazilian market (+19.8\%) but also smaller markets such as in Chile (+197\%) are responsible for the positive trend in this part of the world lasting the third year in a row $(+16.1 \%$ in the period 2012/2013).

Both the MENA region and Sub-Sahara Africa recovered well from a market decline in the period 2011/2012 mainly due to positive market growth rates in Israel (largest market in the MENA region) and South Africa (largest market in Sub-Sahara Africa).

The market for water collectors in the United States and Canada significantly decreased in the period 2010/2011 $(-15.2 \%)$, recovered in $2011 / 2012(+1.3 \%)$ and dropped again in $2012 / 2013(-4.6 \%)$

In Australia, the market for water collectors declined for a fourth year in a row, $-5.4 \%$ in the period 2009/2010, $-10.4 \%$ in the period $2010 / 2011,-4.8 \%$ in the period $2011 / 2012$ and [pm4] $-9.1 \%$ in the period 2012/2013. 


\begin{tabular}{|c|c|c|c|c|c|c|}
\hline \multirow{2}{*}{ Country } & \multicolumn{3}{|c|}{ Water Collectors $\left[\mathrm{MW}_{\text {th }}\right]$} & \multicolumn{2}{|c|}{ Air Collectors $\left[\mathrm{MW}_{\text {th }}\right]$} & \multirow{2}{*}{ TOTAL $\left[\mathrm{MW}_{\mathrm{th}}\right]$} \\
\hline & unglazed & FPC & ETC & unglazed & glazed & \\
\hline Albania & & 20.8 & 0.2 & & & 21 \\
\hline Australia & 455.0 & 115.6 & 14.7 & 24.5 & 0.7 & 611 \\
\hline Austria & 1.0 & 122.6 & 2.8 & & 0.7 & 127 \\
\hline Belgium & & 34.0 & 7.4 & & & 41 \\
\hline Brazil & 435.1 & 523.1 & 6.9 & & & 965 \\
\hline Bulgaria & & 3.6 & 0.4 & & & 4 \\
\hline Canada & 15.3 & 2.2 & 2.6 & 16.7 & 3.9 & 41 \\
\hline Chile & & 41.5 & & & & 42 \\
\hline China & & $4,550.0$ & $39,942.0$ & & & 44,492 \\
\hline Croatia & & 12.9 & 1.8 & & & 15 \\
\hline Cyprus & 0.0 & 12.5 & 0.3 & & & 13 \\
\hline Czech Republic & 24.5 & 22.6 & 8.6 & & & 56 \\
\hline Denmark & & 72.5 & 0.3 & & & 73 \\
\hline Estonia & & 0.7 & 0.7 & & & 1 \\
\hline Finland & & 2.1 & 0.7 & & & 3 \\
\hline France (mainland) + & & 119.9 & 13.8 & 0.4 & & 134 \\
\hline Germany & & 635.6 & 78.4 & & & 714 \\
\hline Greece & & 158.7 & 0.3 & & & 159 \\
\hline Hungary & 0.6 & 7.4 & 5.3 & 0.1 & 0.1 & 13 \\
\hline India ++ & & 231.0 & 539.0 & & 2.8 & 773 \\
\hline Ireland & & 11.4 & 7.3 & & & 19 \\
\hline Israel & 2.0 & 294.2 & 0.1 & & & 296 \\
\hline Italy & & 183.0 & 24.9 & & & 208 \\
\hline Japan & & 99.8 & 2.0 & & 6.5 & 108 \\
\hline Jordan* & & 38.2 & 9.6 & & & 48 \\
\hline Korea, South & & 33.9 & & & & 34 \\
\hline Latvia & & 1.1 & 0.4 & & & 1 \\
\hline Lebanon & & 15.4 & 24.5 & & & 40 \\
\hline Lithuania & & 0.6 & 1.0 & & & 2 \\
\hline Luxembourg & & 3.5 & 0.7 & & & 4 \\
\hline Macedonia & & 3.6 & 0.3 & & & 4 \\
\hline Malta & & 0.8 & 0.2 & & & 1 \\
\hline Mauritius \# & & 6.2 & & & & 6 \\
\hline Mexico & 69.0 & 60.0 & 60.0 & 0.3 & 0.3 & 190 \\
\hline Morocco & & 25.2 & & & & 25 \\
\hline Mozambique* & & & 0.1 & & & 0 \\
\hline Netherlands & 19.2 & 21.1 & 2.6 & & & 43 \\
\hline Norway & & 2.5 & 0.6 & & 0.9 & 4 \\
\hline Palestinian Territories \# & & 80.5 & 4.9 & & & 85 \\
\hline Poland & & 139.4 & 52.5 & & & 192 \\
\hline Portugal & & 38.1 & 2.0 & & & 40 \\
\hline Romania & & 6.3 & 10.4 & 0.6 & & 17 \\
\hline Russia & & 1.1 & 0.1 & & & 1 \\
\hline Slovakia & & 3.6 & 0.7 & & & 4 \\
\hline Slovenia & & 5.6 & 1.4 & & & 7 \\
\hline South Africa & 35.0 & 36.3 & 28.8 & & & 100 \\
\hline Spain & 2.7 & 155.8 & 4.3 & & & 163 \\
\hline Sweden & 0.2 & 4.3 & 1.7 & & & 6 \\
\hline Switzerland & 7.7 & 75.6 & 9.8 & & & 93 \\
\hline Taiwan & & 77.2 & 7.4 & & & 85 \\
\hline Thailand & & 11.4 & & & & 11 \\
\hline Tunisia & & 48.3 & & & & 48 \\
\hline Turkey & & 757.6 & 586.3 & 0.4 & & 1,344 \\
\hline United Kingdom & & 22.6 & 6.0 & 0.7 & & 29 \\
\hline United States & 540.0 & 156.7 & 8.1 & 7.9 & 5.5 & 718 \\
\hline Zimbabwe & & 1.4 & 1.0 & & & 2 \\
\hline All other countries \# & 84.6 & 479.5 & $2,183.5$ & 2.7 & 1.1 & 2,751 \\
\hline TOTAL & 1,692 & 9,591 & 43,669 & 54 & 22 & 55,028 \\
\hline
\end{tabular}

Note: If no data is given: no reliable database for this collector type is available No data from Barbados, Namibia, New Zealand and Uruguay

* Country market data for new installations in 2013 estimated by AEE INTEC

\# $\quad$ Newly included countries compared to the 2014 edition of this report

$+\quad$ The figures for France relate to Metropolitan France (mainland) only. Overseas Departments were not taken into account in this years statistics.

$++\quad$ The figures for India refer to fiscal year end (April 2013-March 2014)

Table 3: Newly installed capacity in 2013 [ $\left.\mathrm{MW}_{\mathrm{th}} / \mathrm{a}\right]$ 


\begin{tabular}{|c|c|c|c|c|c|c|}
\hline \multirow{2}{*}{ Country } & \multicolumn{3}{|c|}{ Water Collectors $\left[\mathrm{m}^{2}\right]$} & \multicolumn{2}{|c|}{ Air Collectors $\left[\mathrm{m}^{2}\right]$} & \multirow{2}{*}{ TOTAL $\left[\mathrm{m}^{2}\right]$} \\
\hline & unglazed & FPC & ETC & unglazed & glazed & \\
\hline Albania & & 29,680 & 284 & & & 29,964 \\
\hline Australia & 650,000 & 165,200 & 21,000 & 35,000 & 1,000 & 872,200 \\
\hline Austria & 1,460 & 175,140 & 4,040 & & 1,010 & 181,650 \\
\hline Belgium & & 48,500 & 10,500 & & & 59,000 \\
\hline Brazil & 621,616 & 747,282 & 9,909 & & & $1,378,807$ \\
\hline Bulgaria & & 5,100 & 500 & & & 5,600 \\
\hline Canada & 21,804 & 3,125 & 3,650 & 23,904 & 5,584 & 58,067 \\
\hline Chile & & 59,300 & & & & 59,300 \\
\hline China & & $6,500,000$ & $57,060,000$ & & & $63,560,000$ \\
\hline Croatia & & 18,400 & 2,500 & & & 20,900 \\
\hline Cyprus & 33 & 17,807 & 472 & & & 18,312 \\
\hline Czech Republic & 35,000 & 32,306 & 12,225 & & & 79,531 \\
\hline Denmark & & 103,600 & 400 & & & 104,000 \\
\hline Estonia & & 1,000 & 1,000 & & & 2,000 \\
\hline Finland & & 3,000 & 1,000 & & & 4,000 \\
\hline France (mainland) + & & 171,273 & 19,667 & 500 & & 191,440 \\
\hline Germany & & 908,000 & 112,000 & & & $1,020,000$ \\
\hline Greece & & 226,700 & 450 & & & 227,150 \\
\hline Hungary & 800 & 10,500 & 7,500 & 200 & 200 & 19,200 \\
\hline India ++ & & 330,000 & 770,000 & & 4,000 & $1,104,000$ \\
\hline Ireland & & 16,330 & 10,382 & & & 26,712 \\
\hline Israel & 2,800 & 420,300 & 200 & & & 423,300 \\
\hline Italy & & 261,360 & 35,640 & & & 297,000 \\
\hline Japan & & 142,568 & 2,847 & & 9,270 & 154,685 \\
\hline Jordan* & & 54,531 & 13,705 & & & 68,236 \\
\hline Korea, South & & 48,473 & & & & 48,473 \\
\hline Latvia & & 1,500 & 500 & & & 2,000 \\
\hline Lebanon & & 22,000 & 35,000 & & & 57,000 \\
\hline Lithuania & & 800 & 1,400 & & & 2,200 \\
\hline Luxembourg & & 5,000 & 1,000 & & & 6,000 \\
\hline Macedonia & & 5,120 & 453 & & & 5,573 \\
\hline Malta & & 1,083 & 278 & & & 1,361 \\
\hline Mauritius \# & & 8,880 & & & & 8,880 \\
\hline Mexico & 98,550 & 85,725 & 85,725 & 400 & 400 & 270,800 \\
\hline Morocco & & 36,000 & & & & 36,000 \\
\hline Mozambique* & & & 143 & & & 143 \\
\hline Netherlands & 27,396 & 30,079 & 3,696 & & & 61,171 \\
\hline Norway & & 3,536 & 846 & & 1,224 & 5,606 \\
\hline Palestinian Territories \# & & 115,000 & 7,000 & & & 122,000 \\
\hline Poland & & 199,100 & 75,000 & & & 274,100 \\
\hline Portugal & & 54,374 & 2,860 & & & 57,234 \\
\hline Romania & & 9,000 & 14,850 & 800 & & 24,650 \\
\hline Russia & & 1,555 & 135 & & & 1,690 \\
\hline Slovakia & & 5,200 & 1,000 & & & 6,200 \\
\hline Slovenia & & 8,000 & 2,000 & & & 10,000 \\
\hline South Africa & 50,010 & 51,902 & 41,187 & & & 143,099 \\
\hline Spain & 3,794 & 222,552 & 6,169 & & & 232,515 \\
\hline Sweden & 351 & 6,124 & 2,487 & & & 8,962 \\
\hline Switzerland & 10,952 & 107,962 & 14,012 & & & 132,926 \\
\hline Taiwan & & 110,221 & 10,616 & & & 120,838 \\
\hline Thailand & & 16,251 & & & & 16,251 \\
\hline Tunisia & & 69,070 & & & & 69,070 \\
\hline Turkey & & $1,082,308$ & 837,539 & 500 & & $1,920,347$ \\
\hline United Kingdom & & 32,234 & 8,566 & 1,000 & & 41,800 \\
\hline United States & 771,400 & 223,800 & 11,600 & 11,300 & 7,800 & $1,025,900$ \\
\hline Zimbabwe & & 1,995 & 1,415 & & & 3,410 \\
\hline All other countries \# & 120,840 & 685,045 & $3,119,229$ & 3,874 & 1,605 & $3,930,592$ \\
\hline TOTAL & $2,416,806$ & $13,700,891$ & $62,384,577$ & 77,478 & 32,093 & $78,611,845$ \\
\hline
\end{tabular}

Note: If no data is given: no reliable database for this collector type is available No data from Barbados, Namibia, New Zealand and Uruguay

* Country market data for new installations in 2013 estimated by AEE INTEC

\# $\quad$ Newly included countries compared to the 2014 edition of this report

$+\quad$ The figures for France relate to Metropolitan France (mainland) only. Overseas Departments were not taken into account in this years statistics.

$++\quad$ The figures for India refer to fiscal year end (April 2013-March 2014)

Table 4: Newly installed collector area in 2013 [m²/a] 
New installations in 2013 are divided into flat plate collectors: $9.6 \mathrm{GW}_{\text {th }}$ (13.7 million square meters), evacuated tube collectors: $43.7 \mathrm{GW}_{\text {th }}$ ( 62.4 million square meters), unglazed water collectors: $1.7 \mathrm{GW}_{\text {th }}$ (2.4 million square meters, ) and glazed and unglazed air collectors: $0.08 \mathrm{GW}_{\text {th }}(0.11$ million square meters).

With a share of $79.4 \%$, evacuated tube collectors are by far the most important solar thermal collector technology worldwide (Figure 18). In a global context, this breakdown is mainly driven by the dominance of the Chinese market where around $90 \%$ of all newly installed collectors in 2013 were evacuated tube collectors.

By contrast, in Europe the situation is almost the opposite with $74.9 \%$ of all solar thermal systems installed in 2013 being flat plate collectors (Figure 19).

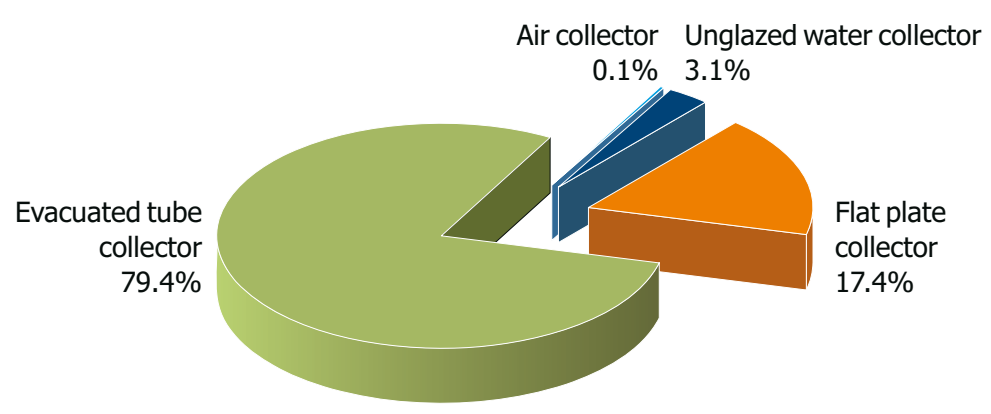

Figure 18: Distribution of the newly installed capacity by collector type in 2013 - WORLD

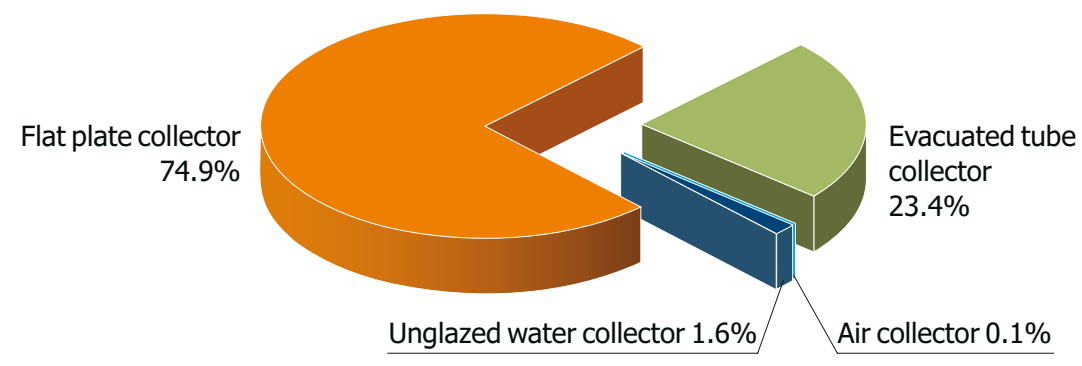

Figure 19: Distribution of the newly installed capacity by collector type in 2013 - EUROPE Europe: EU 28, Albania, Macedonia, Norway, Russia, Switzerland, Turkey

Figure 20 shows the newly installed capacity of glazed and unglazed water collectors for the 10 leading markets in 2013 in total numbers. Compared to the newly installed capacity in 2012, China remained the market leader in absolute terms followed by Turkey.

India faced a significant market decline in 2013 and hence fell behind Brazil within the top 10 ranking. Despite a market decline in the period 2012/2013 Germany remained fifth followed by the United States and Australia. 
44,492

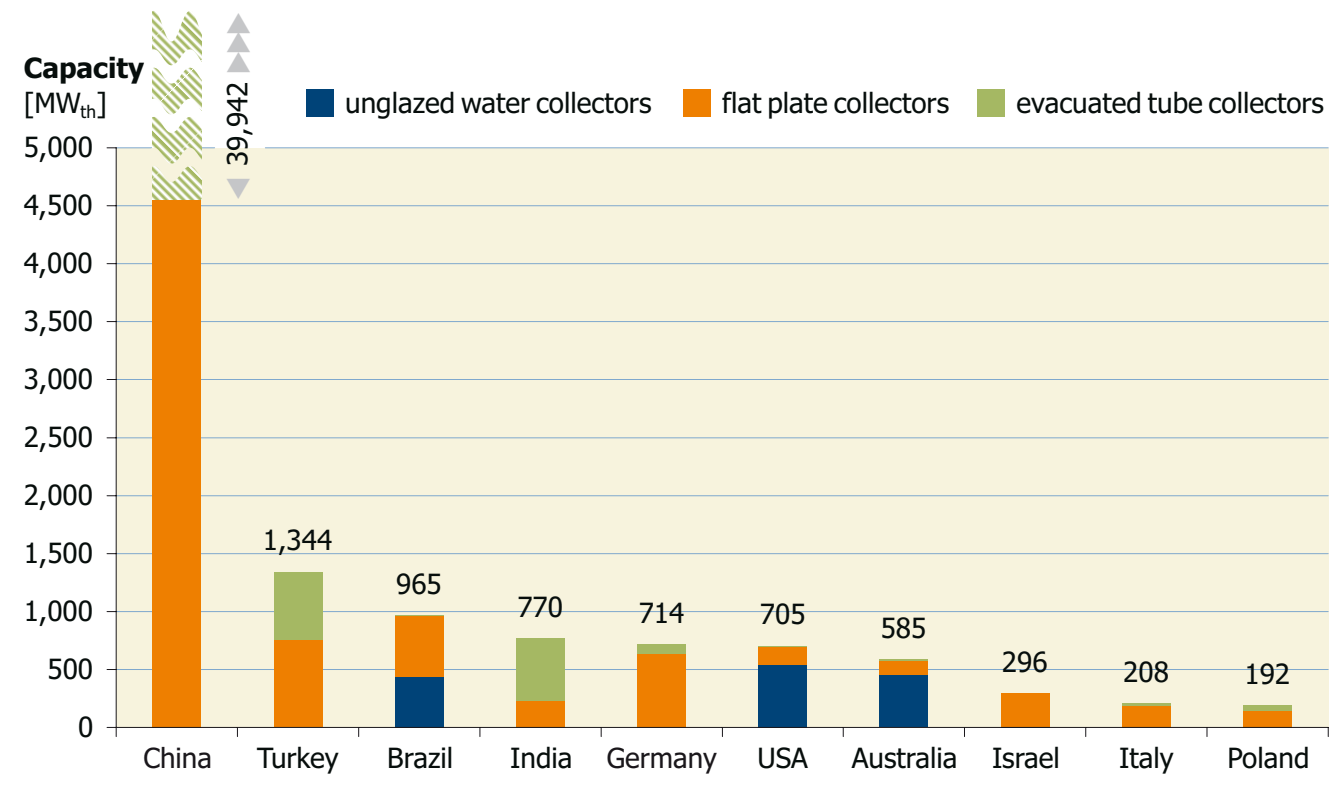

Figure 20: Top 10 markets for glazed and unglazed water collectors in 2013 (absolute figures in $\mathrm{MW}_{\text {th }}$ )

In terms of newly installed solar thermal capacity per 1,000 inhabitants in 2013 Israel took over the lead again, ahead of China and Australia. Palestinian Territories (West Bank and Gaza Strip) were covered the first time in this market report showing a high per capita market penetration, even ahead of the mature solar thermal markets in Turkey, Austria and Greece.

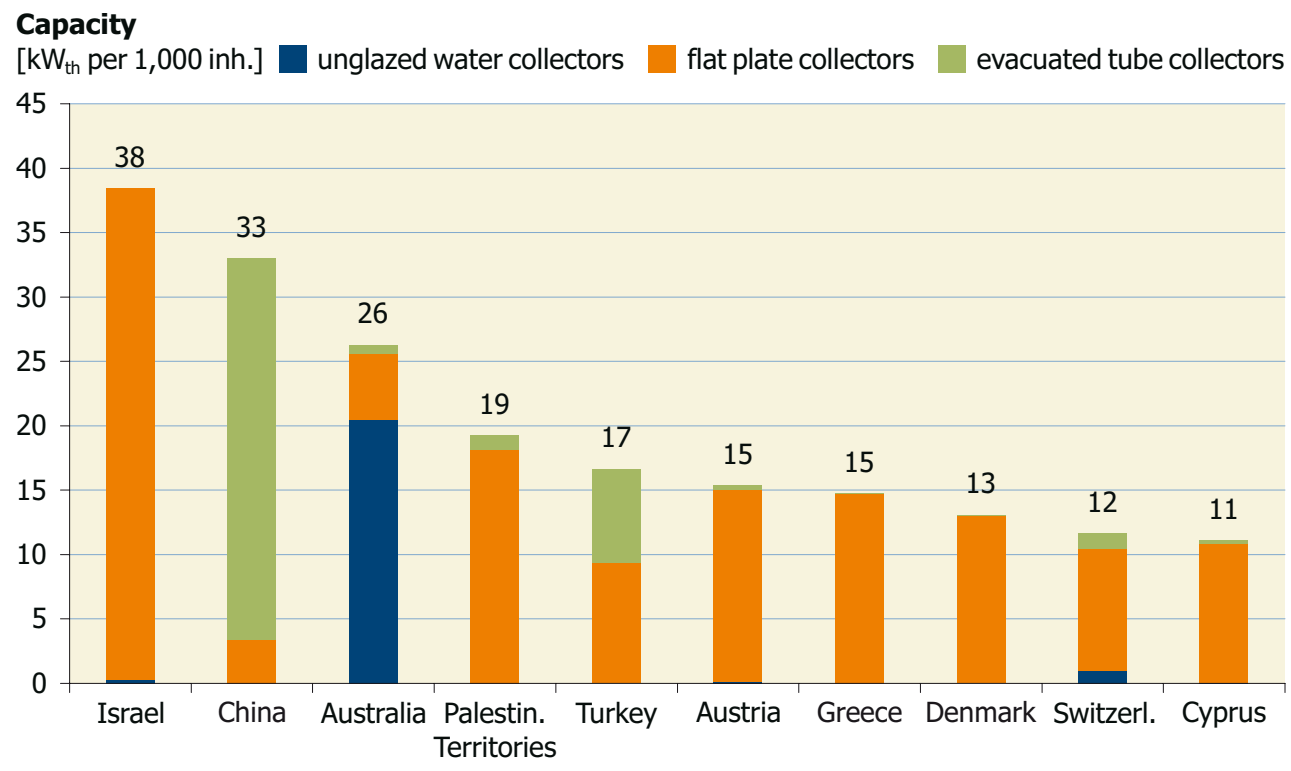

Figure 21: Top 10 markets for glazed and unglazed water collectors in 2013 (relative figures in $\mathrm{kW}_{\text {th }}$ per 1,000 inhabitants) 


\subsection{Newly installed capacity of glazed water collectors}

In 2013 glazed water collectors accounted for $96.8 \%$ of the total newly installed capacity and with a market share of 83.5\% China is the most influencing market in a global context (Figure 22).

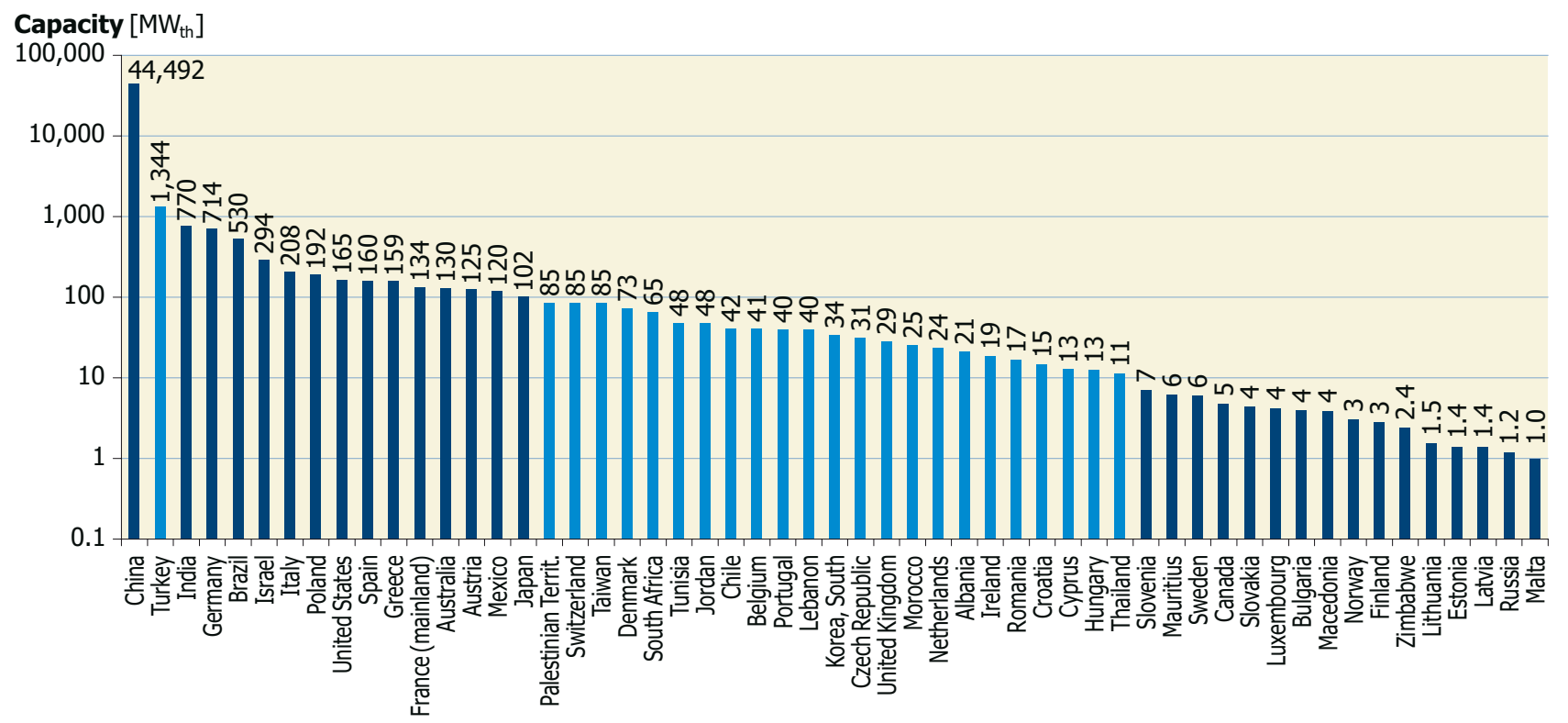

Figure 22: Newly installed capacity of glazed water collectors in 2013

In terms of newly installed glazed water collector capacity per 1,000 inhabitants, Israel is the leader ahead of China and the Palestinian Territories (Figure 23).

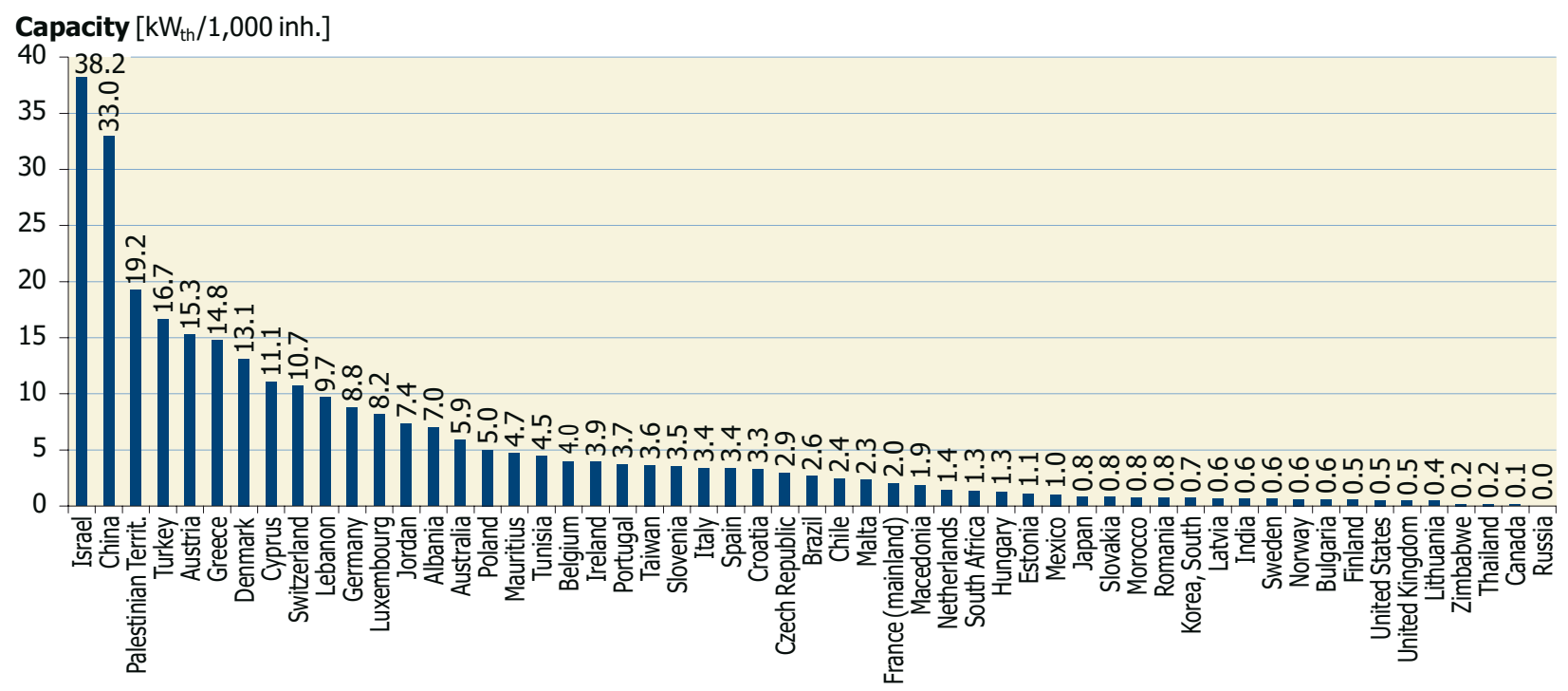

Figure 23: Newly installed capacity of glazed water collectors in 2013 in kW th per 1,000 inhabitants 


\subsection{Market development of glazed water collectors between 2000 and 2013}

The worldwide market of glazed water collectors was characterized by a steady upwards trend between 2000 and 2011 and shown a leveling trend since 2012. The annual installed capacity increased from around $9.8 \mathrm{GW}_{\text {th }}$ in 2002 to around $53.3 \mathrm{GW}_{\text {th }}$ in 2013 . Compared to the year 2012, the growth rate has dropped from $6.8 \%$ to $1.7 \%$ in 2013 (Figure 24).

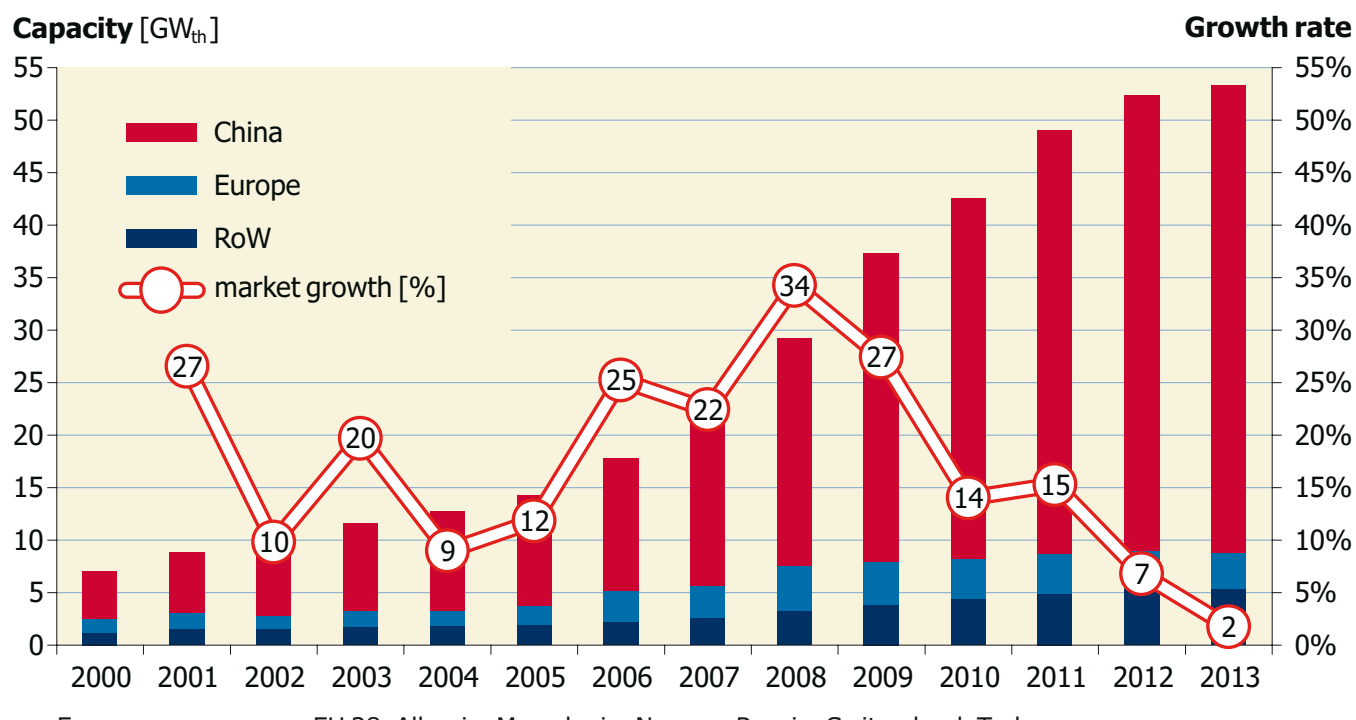

\section{Europe: $\quad$ EU 28, Albania, Macedonia, Norway, Russia, Switzerland, Turkey}

Rest of World (RoW): Asia (India, Japan, Korea South, Taiwan, Thailand), Australia, Canada, Latin America (Barbados, Brazil, Chile, Mexico, Uruguay), New Zealand, MENA Region (Israel, Jordan, Lebanon, Morocco, Palestinian Territories, Tunisia), Sub-Sahara Africa (Mauritius, Mozambique, Namibia, South Africa, Zimbabwe), USA

Figure 24: Global market development of glazed water collectors from 2000 to 2013

In 2000 the Chinese market was about three times as large as the European market while in 2013 the Chinese market volume exceeded it thirteen-fold (Figure 25).

It can be also seen in Figure $\mathbf{2 5}$ that after years of very high growth rates in China this trend ended and the market started to stagnate in 2012 and 2013. For the year 2014 preliminary market data from the Chinese Solar Thermal Industry Federation (CSTIF) reports a significant decline in sales numbers of $-17.6 \%$.

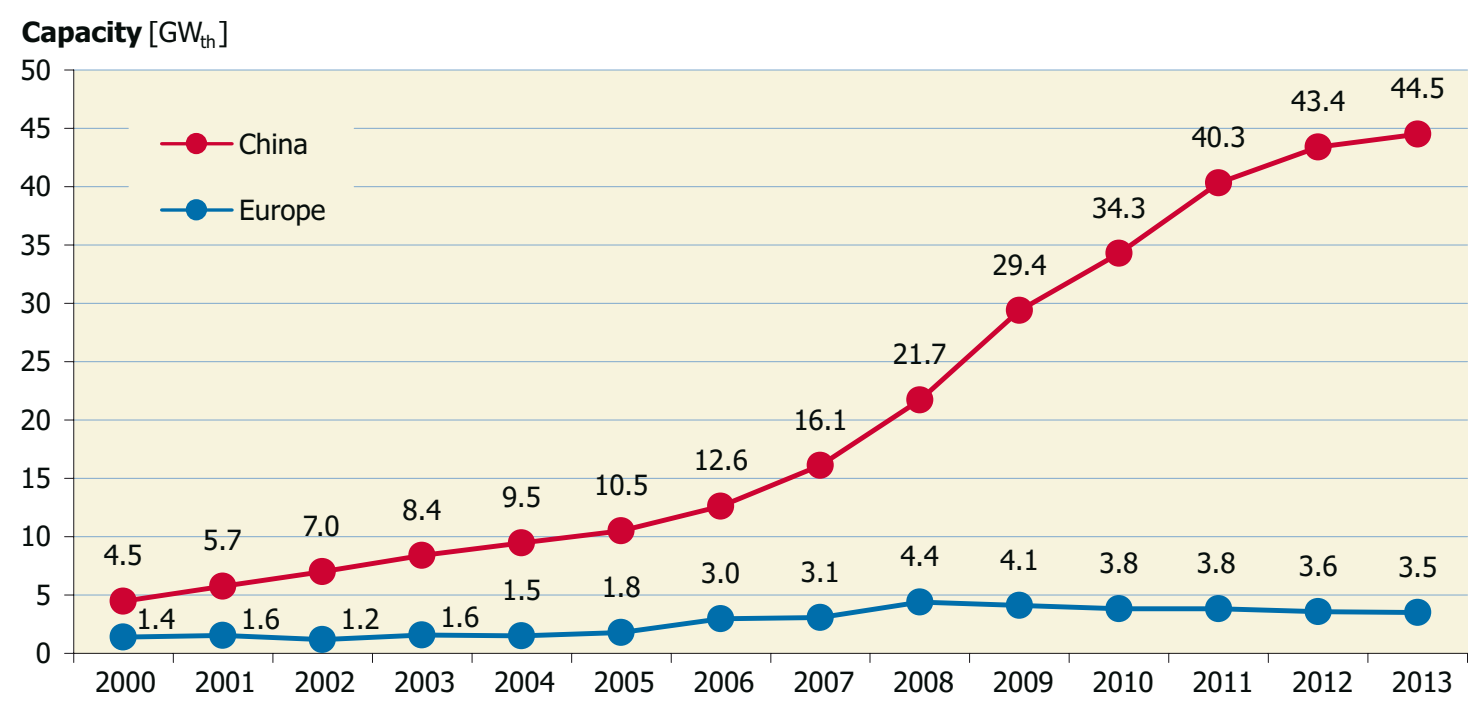

Figure 25: Market development of glazed water collectors in China and Europe 
The European market peaked at $4.4 \mathrm{GW}_{\text {th }}$ installed capacity in 2008 and decreased steadily down to $3.5 \mathrm{GW}_{\text {th }}$ in 2013. By contrast, in the remaining markets worldwide (RoW) an upwards trend could be observed between 2002 and 2012 with a declining tendency as well in 2013 (Figure 26).

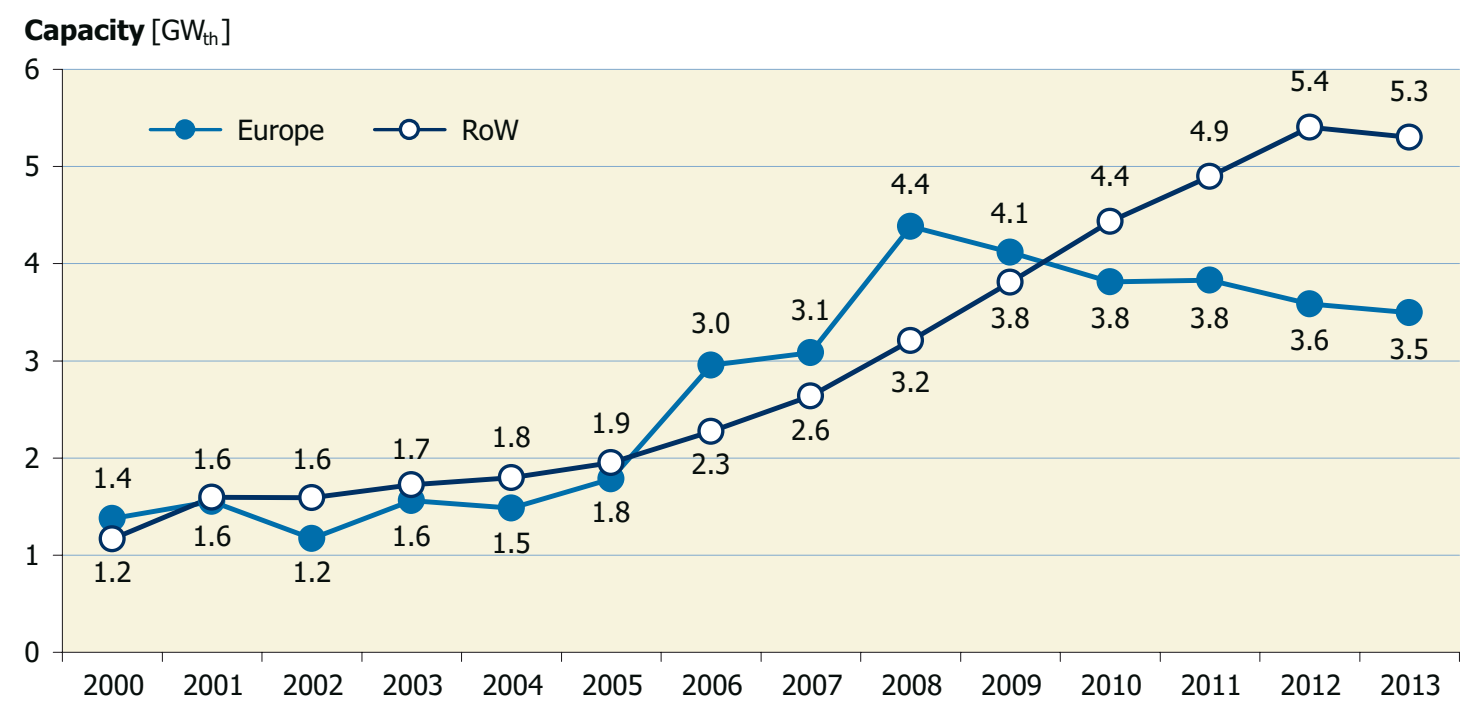

Figure 26: Market development of glazed water collectors in Europe and the rest of the world (RoW, excluding China)

RoW includes all economic regions other than China and Europe as well as "All other countries" not covered within this report. Of these regions, "All other countries", Asia (excluding China) and Latin America hold the largest market shares (see Figure 27).

"Asia excl. China" is highly influenced by the large Indian market, which dropped significantly in 2013, but also the markets in Japan, South Korea and Thailand decreased. In sum this led to a market decline of $-20.3 \%$ for this economic region compared to a positive market growth rate of $38.6 \%$ in 2012. According to the Ministry of New and Renewable Energy (MNRE), the Indian authority responsible for solar heating statistics, in 2014 the Indian market recovered again.

The third largest region shown in Figure $\mathbf{2 7}$ is Latin America showing a steady upwards trend mainly due to the well growing Brazilian market. The MENA region recovered from a market decline in 2012 with Israel as the most important market driver.

Sub-Sahara African markets, most notably South Africa, are growing slowly, United States and Canada are more or less stagnating while the Australian market is constantly shrinking. The annually installed capacity in the latter fell from $364 \mathrm{MW}_{\text {th }}$ in 2009 to $130 \mathrm{MW}_{\text {th }}$ in 2013. 


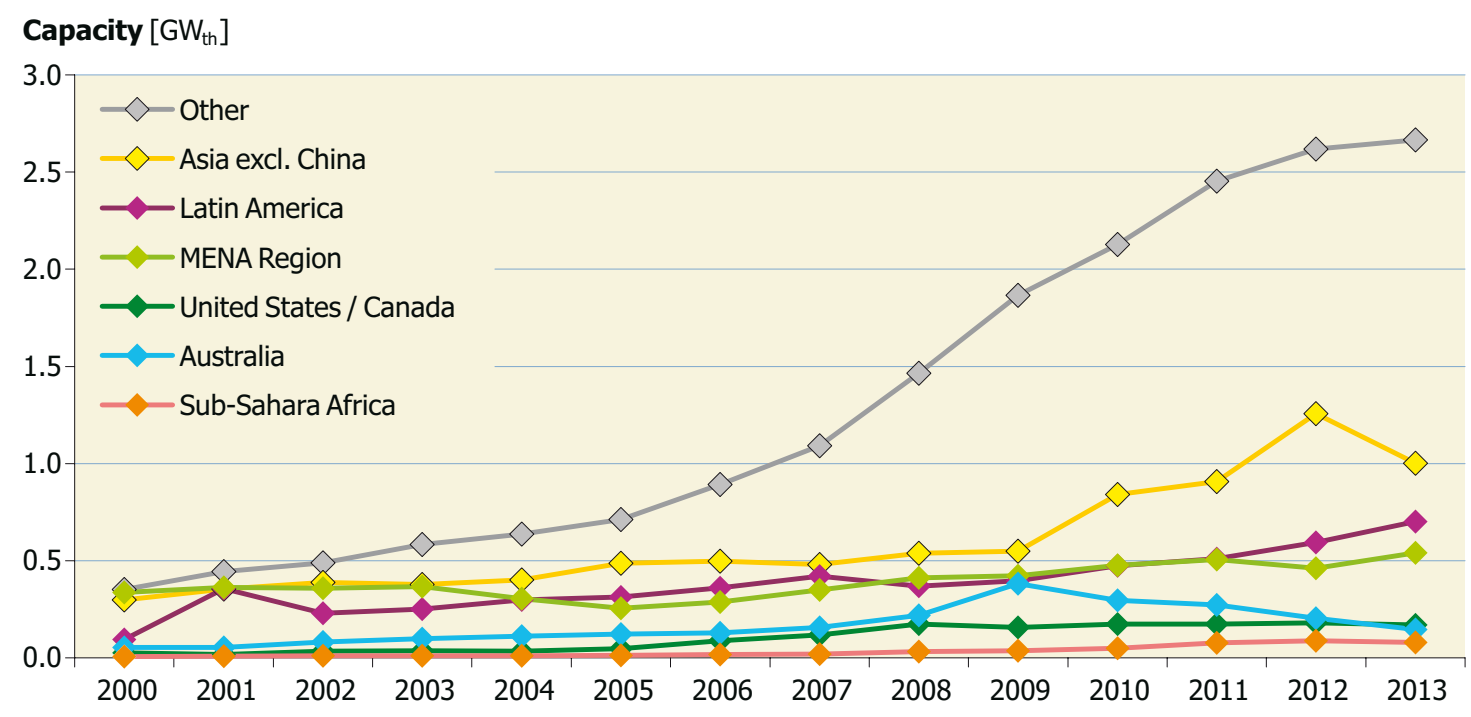

Figure 27: Market development of glazed water collectors in Rest of World (excluding China and Europe)

In relative figures, the annual global market volume for glazed water collectors grew from $1.2 \mathrm{~kW}_{\text {th }}$ per 1,000 inhabitants in 2000 to $7.5 \mathrm{~kW}_{\text {th }}$ per 1,000 inhabitants in 2012 (Figure 28).

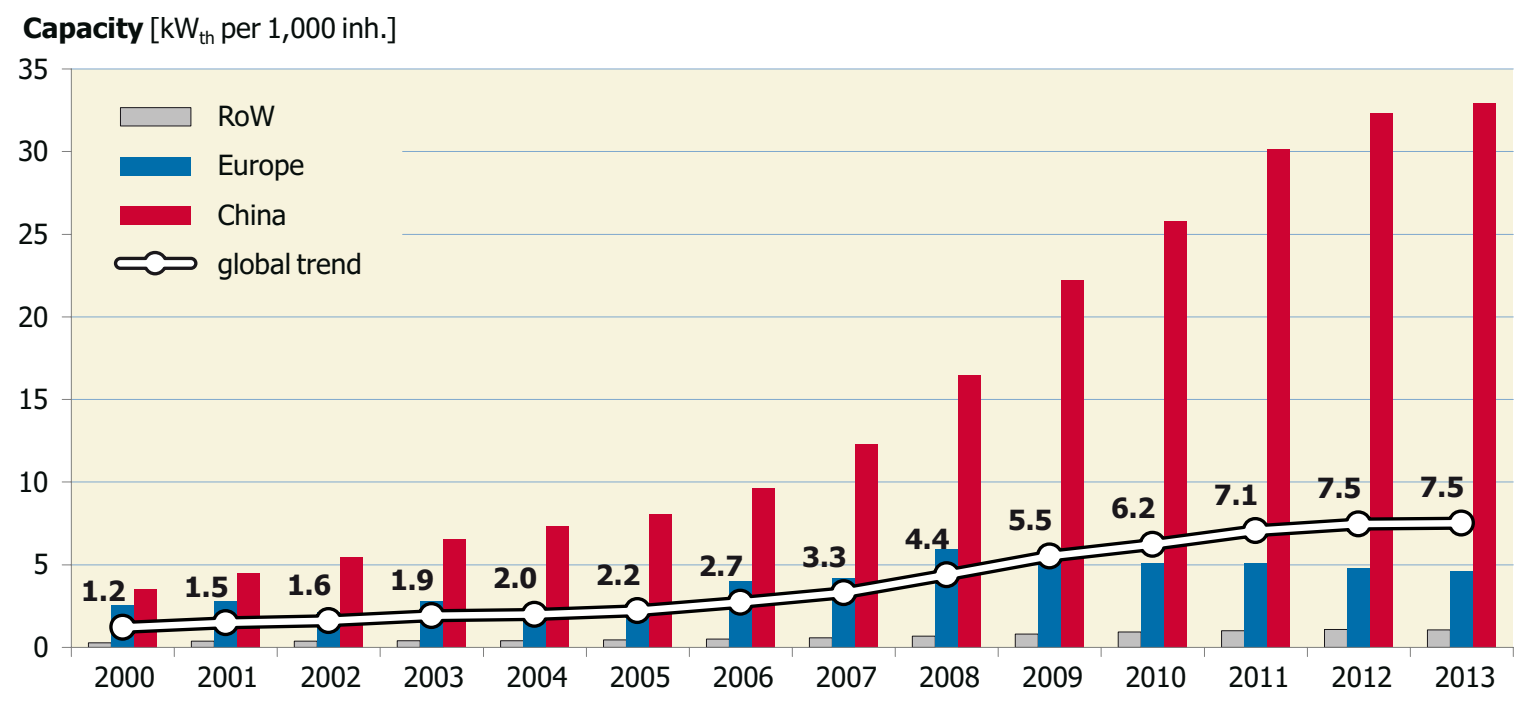

Figure 28: Annual installed capacity of glazed water collectors in kWth per 1,000 inhabitants from 2000 to 2013

It can be highlighted that in 2013 China had the second highest market penetration in terms of glazed water collector installations per capita compared to all other countries covered in this report. The annually installed capacity rose from $3.5 \mathrm{~kW}_{\text {th }}$ per 1,000 inhabitants in 2000 to $33.5 \mathrm{~kW}_{\text {th }}$ per 1,000 inhabitants in 2013. Worldwide, only Israel showed a higher market penetration of $38.2 \mathrm{~kW}_{\text {th }}$ per 1,000 inhabitants in 2013 as can be seen in Figure 23.

In Europe, the market penetration peaked in 2008 with $5.9 \mathrm{~kW}_{\text {th }}$ per 1,000 inhabitants and since then a constant downwards trend in per capita installations can be observed leading to a value of $4.7 \mathrm{~kW}_{\text {th }}$ per 1,000 inhabitants in 2013. 


\subsection{Market development of unglazed water collectors between 2000 and 2013}

In 2013 unglazed water collectors accounted for 3.1\% of the total installed capacity (Figure 18) and compared to the year 2012 the market grew moderately by $1.5 \%$.

The most important markets for unglazed collectors in 2013 were the United States (540 MW (455 $\mathrm{MW}_{\text {th }}$ ) and Brazil (435 $\mathrm{MW}_{\text {th }}$ ). These three countries accounted for $85 \%$ of the recorded unglazed water collector installations.

Another $10 \%$ were installed in Mexico $\left(69 \mathrm{MW}_{\text {th }}\right)$, South Africa (35 $\left.\mathrm{MW}_{\text {th }}\right)$, the Czech Republic (25 MW th), the Netherlands (19 $\mathrm{MW}_{\mathrm{th}}$ ) and Canada (15 $\left.\mathrm{MW}_{\mathrm{th}}\right)$.

RoW includes several smaller markets in Europe and the MENA region as well as "other countries" not considered in this report and hence estimated to be $5 \%$ of the total market for unglazed water collectors.

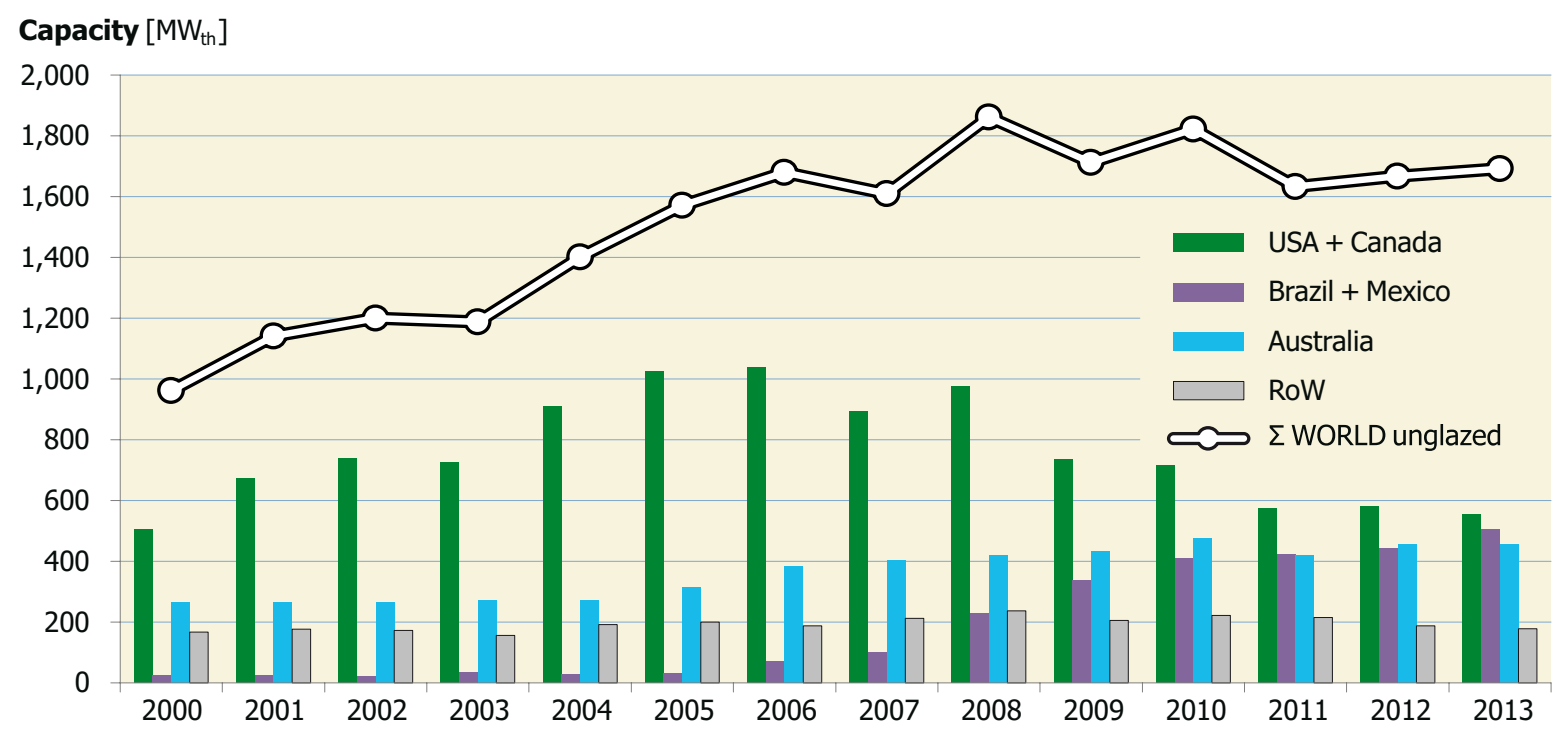

Figure 29: Global market development of unglazed water collectors from 2000 to 2013

The unglazed water collector market in the United States peaked in 2006 (1.01 GW $\mathrm{th}_{\mathrm{th}}$ ) and almost halved since then (0.54 GW $\mathrm{Gh}_{\text {th }}$ in 2013). Nevertheless, the annual market volume for unglazed water collectors remained at quite a constant level because of the Brazilian market, which entered in 2007 and has grown steeply since then. 


\section{Contribution to the energy supply and $\mathrm{CO}_{2}$ reduction}

In this section, the contribution of the total installed glazed and unglazed water collectors in operation to the thermal energy supply and $\mathrm{CO}_{2}$ reduction is shown.

The basis for these calculations is the total glazed and unglazed water collector area in operation in each country as shown in Table 1. The contribution of the total installed air collector capacity in operation in 2013 of $1.7 \mathrm{GW}_{\text {th }}$ was not taken into consideration - with a share of around $0.4 \%$ of the total installed collector capacity these collectors were omitted from the calculation.

The results are based on calculations using the simulation tool T-SOL expert 4.5 (www.valentin-software.com) for each country. For the simulations, different types of collectors and applications as well as the characteristic climatic conditions were considered for each country. A more detailed description of the methodology can be found in the appendix (see Chapter 8).

The annual collector yield of all water-based solar thermal systems in operation by the end of 2013 in the 60 recorded countries was $314 \mathrm{TWh}(=1,129 \mathrm{PJ})$. This corresponds to an energy savings equivalent of 33.7 million tons of oil and 109 million tons of $\mathrm{CO}_{2}$. The calculated number of different types of solar thermal systems in operation was around 111 million (Table 5).

The most important field of application for solar thermal systems is heating domestic hot water (see section 6.3), and therefore, this type of application also accounted for the highest savings in terms of oil equivalent and $\mathrm{CO}_{2}$. In 2013, $94 \%$ of the energy provided by solar thermal systems worldwide was used for heating domestic hot water, mainly by small-scale systems in single family houses (84\%) and larger applications attached to multi-family houses, hotels, schools, etc. (10\%). Swimming pool heating held a share of $4 \%$ in the contribution to the energy supply and $\mathrm{CO}_{2}$ reduction and the remaining $2 \%$ were met by solar combi systems.

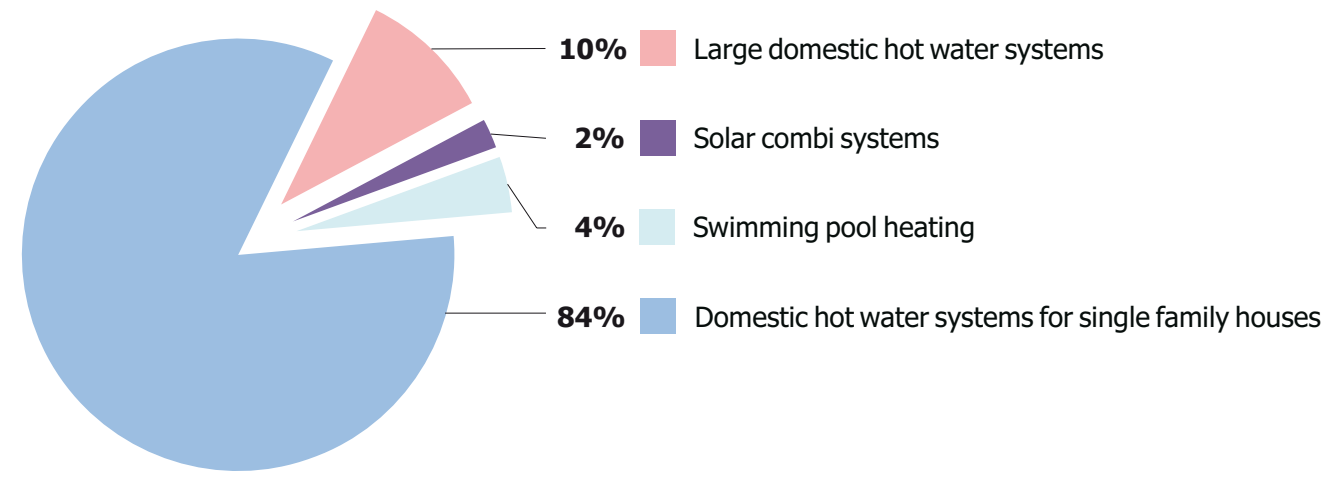

Figure 30: Share of energy savings and $\mathrm{CO}_{2}$ reduction by type of application of glazed and unglazed water collectors in operation by the end of 2013

Table 5 summarizes the calculated annual collector yields and the corresponding oil equivalents and $\mathrm{CO}_{2}$ reductions of all water-based solar thermal systems (systems for hot water, space heating and swimming pool heating) in operation by the end of 2013. 


\begin{tabular}{|c|c|c|c|c|c|c|}
\hline Country & $\begin{array}{c}\text { Total } \\
\text { collector area } \\
{\left[\mathrm{m}^{2}\right]}\end{array}$ & $\begin{array}{c}\text { Total } \\
\text { capacity } \\
{\left[\mathrm{MW}_{\text {th }}\right]}\end{array}$ & $\begin{array}{c}\text { Calculated } \\
\text { number } \\
\text { of systems }\end{array}$ & $\begin{array}{l}\text { Collector } \\
\text { yield } \\
\text { [GWh/a] }\end{array}$ & $\begin{array}{c}\text { Energy } \\
\text { savings } \\
{\left[t_{o o} / a\right]}\end{array}$ & $\begin{array}{c}\mathrm{CO}_{2} \\
\text { reduction } \\
{\left[\mathrm{t}_{\mathrm{CO} 2} / \mathrm{a}\right]}\end{array}$ \\
\hline Albania & 141,885 & 99 & 18,188 & 99 & 10,664 & 34,473 \\
\hline Australia & $8,023,000$ & 5,616 & $1,024,556$ & 4,992 & 536,591 & $1,734,637$ \\
\hline Austria & $5,056,098$ & 3,539 & 503,348 & 2,044 & 219,716 & 710,276 \\
\hline Barbados & 131,690 & 92 & 26,977 & 112 & 12,024 & 38,869 \\
\hline Belgium & 487,783 & 341 & 99,922 & 199 & 21,379 & 69,112 \\
\hline Brazil & $9,609,263$ & 6,726 & $1,549,301$ & 6,407 & 688,607 & $2,226,059$ \\
\hline Bulgaria & 126,200 & 88 & 23,209 & 66 & 7,071 & 22,859 \\
\hline Canada & 889,370 & 623 & 14,894 & 423 & 45,489 & 147,051 \\
\hline Chile & 139,309 & 98 & 17,525 & 105 & 11,232 & 36,310 \\
\hline China & $374,660,000$ & 262,262 & $85,403,747$ & 217,841 & $23,413,743$ & $75,689,608$ \\
\hline Croatia & 145,565 & 102 & 29,819 & 75 & 8,093 & 26,164 \\
\hline Cyprus & 700,947 & 491 & 154,463 & 623 & 66,964 & 216,475 \\
\hline Czech Republic & 971,269 & 680 & 68,205 & 332 & 35,636 & 115,202 \\
\hline Denmark & 785,090 & 550 & 91,965 & 335 & 35,964 & 116,260 \\
\hline Estonia & 8,520 & 6 & 1,745 & 4 & 379 & 1,225 \\
\hline Finland & 52,202 & 37 & 10,694 & 22 & 2,358 & 7,621 \\
\hline France (mainland) & $2,370,399$ & 1,659 & 372,260 & 1,144 & 122,955 & 397,476 \\
\hline Germany & $17,514,176$ & 12,260 & $1,915,127$ & 7,124 & 765,699 & $2,475,274$ \\
\hline Greece & $4,178,350$ & 2,925 & $1,612,857$ & 3,207 & 344,706 & $1,114,330$ \\
\hline Hungary & 252,100 & 176 & 29,185 & 114 & 12,215 & 39,489 \\
\hline India & $6,231,200$ & 4,362 & $1,125,978$ & 5,221 & 561,170 & $1,814,094$ \\
\hline Ireland & 277,619 & 194 & 64,250 & 116 & 12,493 & 40,386 \\
\hline Israel & $4,150,115$ & 2,905 & $1,372,992$ & 3,888 & 417,912 & $1,350,983$ \\
\hline Italy & $3,692,896$ & 2,585 & 632,778 & 2,266 & 243,579 & 787,419 \\
\hline Japan & $4,074,396$ & 2,852 & 995,253 & 2,366 & 254,254 & 821,926 \\
\hline Jordan & $1,192,270$ & 835 & 211,031 & 1,129 & 121,342 & 392,261 \\
\hline Korea, South & $1,762,570$ & 1,234 & 254,163 & 871 & 93,632 & 302,683 \\
\hline Latvia & 6,040 & 4 & 1,237 & 3 & 286 & 923 \\
\hline Lebanon & 561,000 & 393 & 60,251 & 465 & 49,934 & 161,421 \\
\hline Lithuania & 8,200 & 6 & 1,680 & 4 & 380 & 1,229 \\
\hline Luxembourg & 45,800 & 32 & 9,382 & 20 & 2,134 & 6,899 \\
\hline Macedonia & 47,130 & 33 & 10,613 & 29 & 3,131 & 10,122 \\
\hline Malta & 48,448 & 34 & 9,925 & 40 & 4,320 & 13,966 \\
\hline Mauritius & 115,113 & 81 & 61,952 & 94 & 10,139 & 32,777 \\
\hline Mexico & $2,497,077$ & 1,748 & 129,536 & 1,372 & 147,472 & 476,732 \\
\hline Morocco & 415,000 & 291 & 85,013 & 354 & 38,076 & 123,089 \\
\hline Mozambique & 416 & 0 & 85 & 0 & 36 & 118 \\
\hline Namibia & 22,006 & 15 & 2,718 & 20 & 2,158 & 6,975 \\
\hline Netherlands & 880,450 & 616 & 132,899 & 310 & 33,302 & 107,655 \\
\hline New Zealand & 159,645 & 112 & 32,703 & 99 & 10,592 & 34,241 \\
\hline Norway & 39,576 & 28 & 1,502 & 15 & 1,573 & 5,084 \\
\hline Palestinian Territ. & $1,627,000$ & 1,139 & 979,454 & 1,580 & 169,832 & 549,015 \\
\hline Poland & $1,485,000$ & 1,040 & 186,863 & 606 & 65,177 & 210,698 \\
\hline Portugal & 904,629 & 633 & 172,974 & 701 & 75,370 & 243,650 \\
\hline Romania & 128,550 & 90 & 26,333 & 73 & 7,864 & 25,422 \\
\hline Russia & 18,213 & 13 & 825 & 8 & 815 & 2,635 \\
\hline Slovakia & 150,200 & 105 & 20,755 & 71 & 7,603 & 24,577 \\
\hline Slovenia & 186,800 & 131 & 28,250 & 78 & 8,353 & 27,003 \\
\hline South Africa & $1,506,611$ & 1,055 & 148,948 & 1,056 & 113,516 & 366,964 \\
\hline Spain & $3,195,339$ & 2,237 & 375,932 & 2,228 & 239,497 & 774,222 \\
\hline Sweden & 454,000 & 318 & 34,572 & 166 & 17,835 & 57,655 \\
\hline Switzerland & $1,384,940$ & 969 & 167,565 & 547 & 58,786 & 190,038 \\
\hline Taiwan & $1,545,628$ & 1,082 & 304,849 & 940 & 101,082 & 326,767 \\
\hline Thailand & 136,611 & 96 & 27,985 & 110 & 11,871 & 38,376 \\
\hline Tunisia & 706,380 & 494 & 247,039 & 635 & 68,239 & 220,596 \\
\hline Turkey & $15,670,321$ & 10,969 & $3,629,246$ & 14,059 & $1,511,076$ & $4,884,855$ \\
\hline United Kingdom & 743,873 & 521 & 152,382 & 297 & 31,924 & 103,200 \\
\hline United States & $23,842,764$ & 16,690 & 733,165 & 10,873 & $1,168,663$ & $3,777,936$ \\
\hline Uruguay & 12,571 & 9 & 2,575 & 8 & 884 & 2,859 \\
\hline Zimbabwe & 22,978 & 16 & 4,707 & 19 & 2,042 & 6,602 \\
\hline All other countries & $26,641,715$ & 18,649 & $5,472,916$ & 15,682 & $1,685,544$ & $5,448,859$ \\
\hline TOTAL & $532,834,306$ & 372,984 & $110,881,263$ & 313,688 & $33,715,371$ & $108,991,678$ \\
\hline
\end{tabular}

Table 5: Calculated annual collector yield and corresponding oil equivalent and $\mathrm{CO}_{2}$ reduction of glazed and unglazed water collectors in operation by the end of 2013

In Chapters 5.1 to 5.3 , the annual collector yield, energy savings and $\mathrm{CO}_{2}$ savings by economic regions and worldwide are graphed. 


\subsection{Annual collector yield by economic region}

In 2013 gross solar thermal collector yields amounted to 314 TWh worldwide (Table 5) and the major share, 84\%, was contributed by domestic hot water applications for single family houses (Figure $\mathbf{3 0}$ ).

China accounted for $69 \%$ of the thermal energy gains (218 TWh), Europe for $12 \%$ ( 37 TWh) and the Rest of the World for $19 \%$ (42 TWh) (Figure 31).

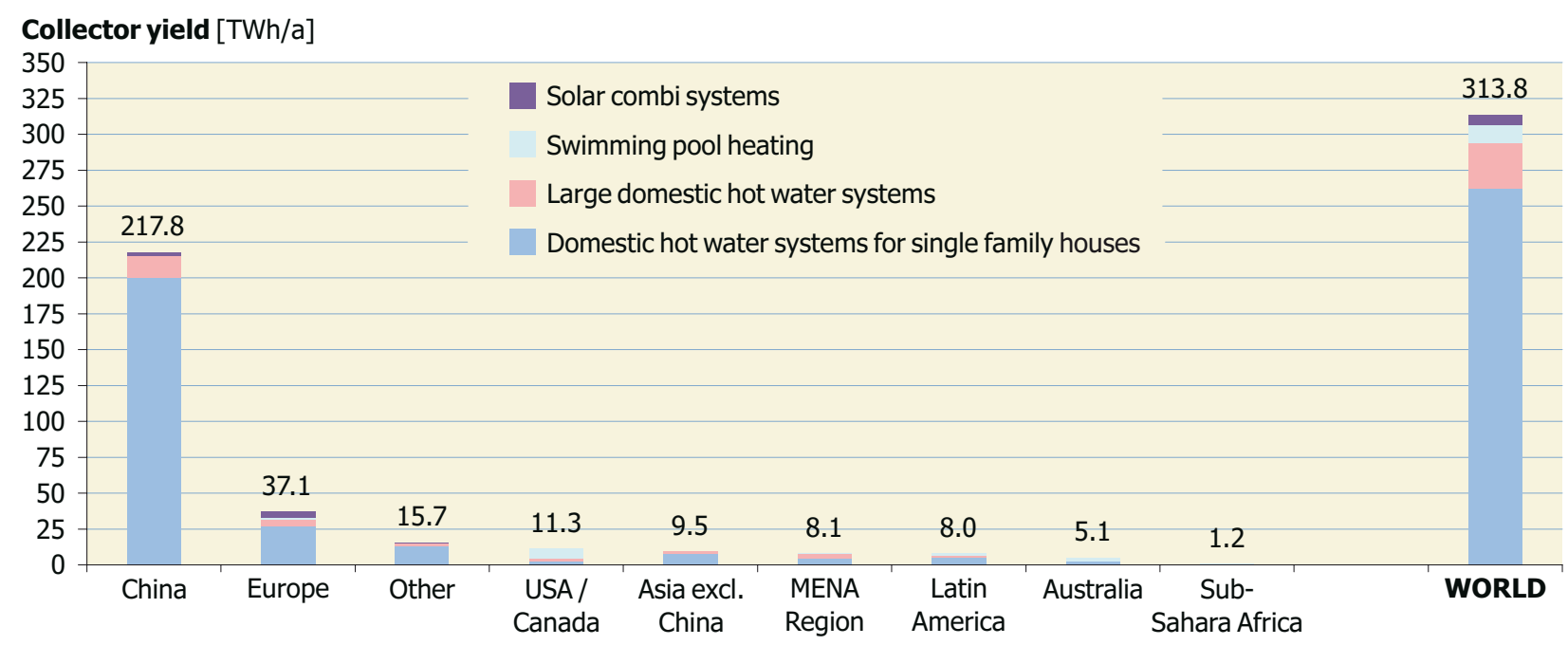

Sub-Sahara Africa: $\quad$ Mauritius, Mozambique, Namibia, South Africa, Zimbabwe

Asia excluding China: India, Japan, Korea South, Taiwan, Thailand

Latin America: $\quad$ Barbados, Brazil, Chile, Mexico, Uruguay

Europe: $\quad$ EU 28, Albania, Macedonia, Norway, Russia, Switzerland, Turkey

MENA Region: Israel, Jordan, Lebanon, Morocco, Palestinian Territories, Tunisia

Figure 31: Annual collector yield of unglazed and glazed water collectors in operation by end of 2013

\subsection{Annual energy savings by economic region}

Considering an utilization ratio of 0.8 for the reference oil boiler, which is assumed to be partly replaced by the solar thermal system (see methodology Chapter 8.1), the annual final energy savings amounted to 314 TWh or 33.7 million tons of oil equivalent in $2013^{5}$.

The breakdown shows that China accounted for 23.4 million tons oil equivalent; Europe for 4.0 million tons oil equivalent, Rest of World for 6.3 million tons oil equivalent (Figure 32). 


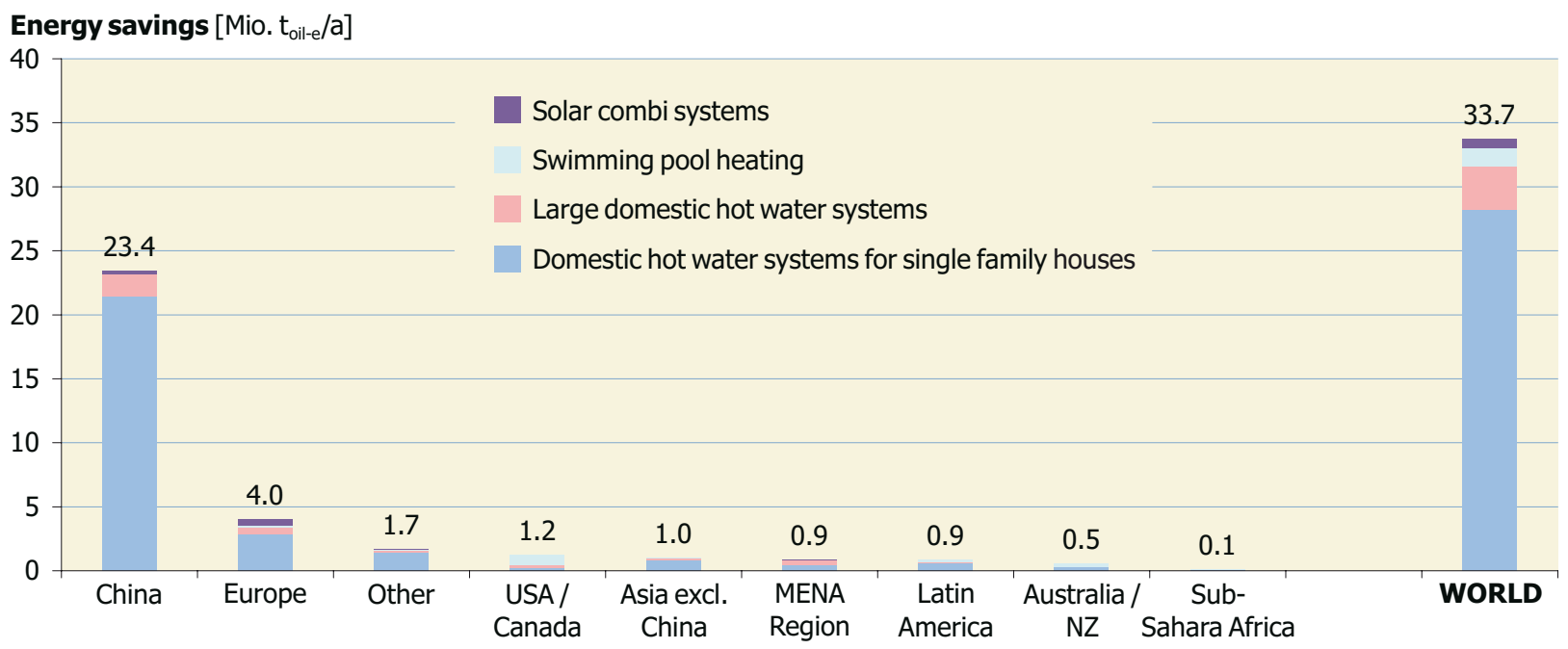

Figure 32: Annual energy savings in oil equivalent by unglazed and glazed water collectors in operation by end of 2013

\subsection{Annual contribution to $\mathrm{CO}_{2}$ reduction by economic region}

33.7 million tons of oil equivalents correspond to an annual $\mathrm{CO}_{2}$ emission reduction of 109 million tons ${ }^{6}$. Here, the breakdown was China 75.7 million tons of $\mathrm{CO}_{2} \mathrm{e}$; Europe 12.9 million tons of $\mathrm{CO}_{2} \mathrm{e}$, Rest of World 20.4 million tons of $\mathrm{CO}_{2} \mathrm{e}$ (see Figure 33).

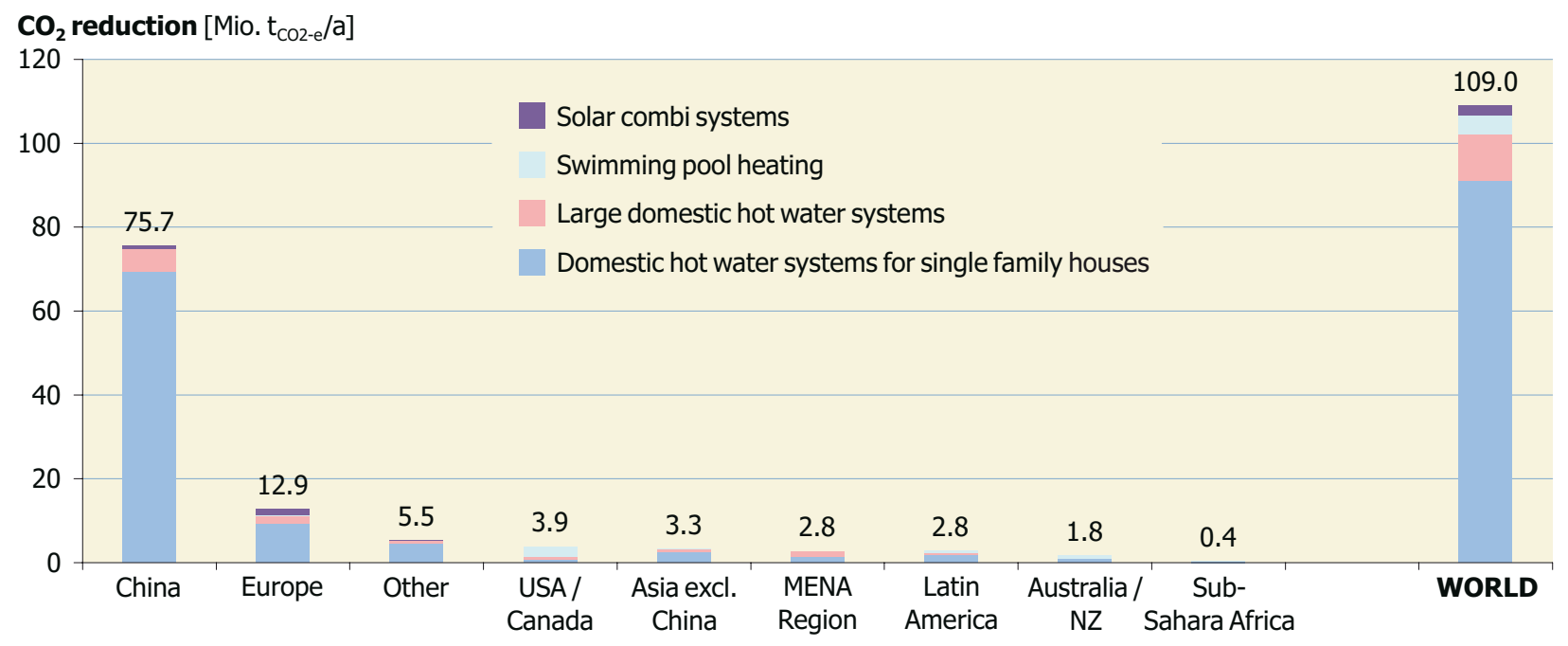

Sub-Sahara Africa: $\quad$ Mauritius, Mozambique, Namibia, South Africa, Zimbabwe

Asia excluding China: India, Japan, Korea South, Taiwan, Thailand

Latin America: Barbados, Brazil, Chile, Mexico, Uruguay

Europe: $\quad$ EU 28, Albania, Macedonia, Norway, Russia, Switzerland, Turkey

MENA Region: $\quad$ Israel, Jordan, Lebanon, Morocco, Palestinian Territories, Tunisia

Figure 33: Contribution to $\mathrm{CO}_{2}$ reduction by unglazed and glazed water collectors in operation by end of 2013 


\section{Distribution of systems by system type and application}

The use of solar thermal energy varies greatly from region to region and can be roughly distinguished by the type of solar thermal collector used (unglazed water collectors, evacuated tube collectors, flat plate collectors, glazed and unglazed air collectors, concentrating collectors), the type of system operation (pumped solar thermal systems, thermosiphon systems), and the main type of application (swimming pool heating, domestic hot water preparation, space heating, others such as heating of industrial processes, solar district heating or solar thermal cooling).

In Chapters 6.1 to 6.3, the share of these system types and applications are shown by different economic regions for both the cumulated capacity in operation by the end of 2013 and the newly installed capacity in $2013^{7}$.

\subsection{Distribution by type of solar thermal collector}

In terms of the total water collector area, evacuated tube collectors dominated with a share of $71 \%$ of the cumulated capacity in operation (Figure 34) and a share of $79 \%$ of the newly installed capacity (Figure 35). Especially in China, vacuum tube collectors played an important role and since this was by far the largest market supported by high growth rates in the past, the worldwide figures tend towards a higher share of this type of solar thermal collector. Unglazed water collectors accounted for $7 \%$ of the cumulated water collectors installed worldwide and for $3 \%$ of the newly installed capacity.

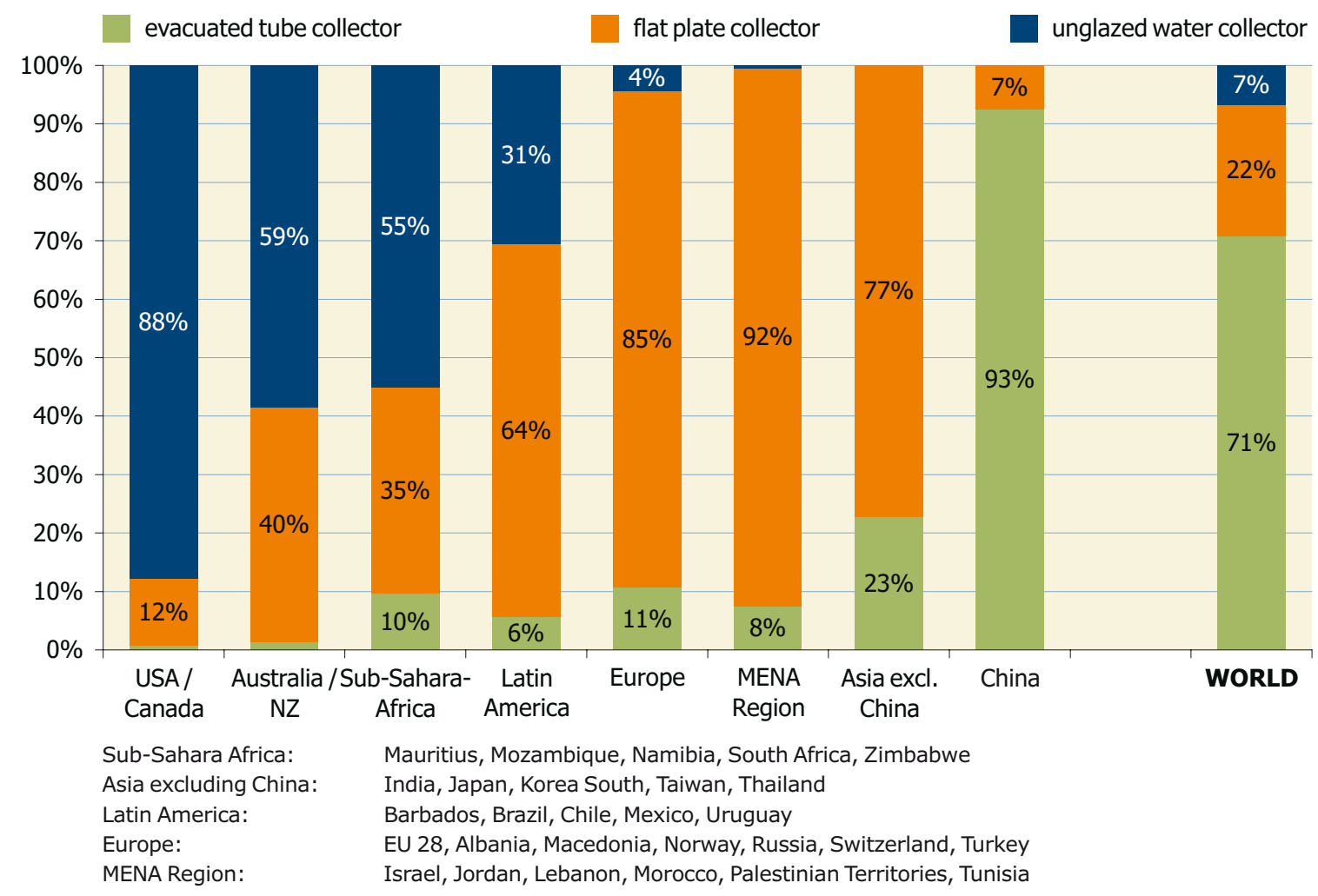

Figure 34: Distribution by type of solar thermal collector for the total installed water collector capacity in operation by the end of 2013 


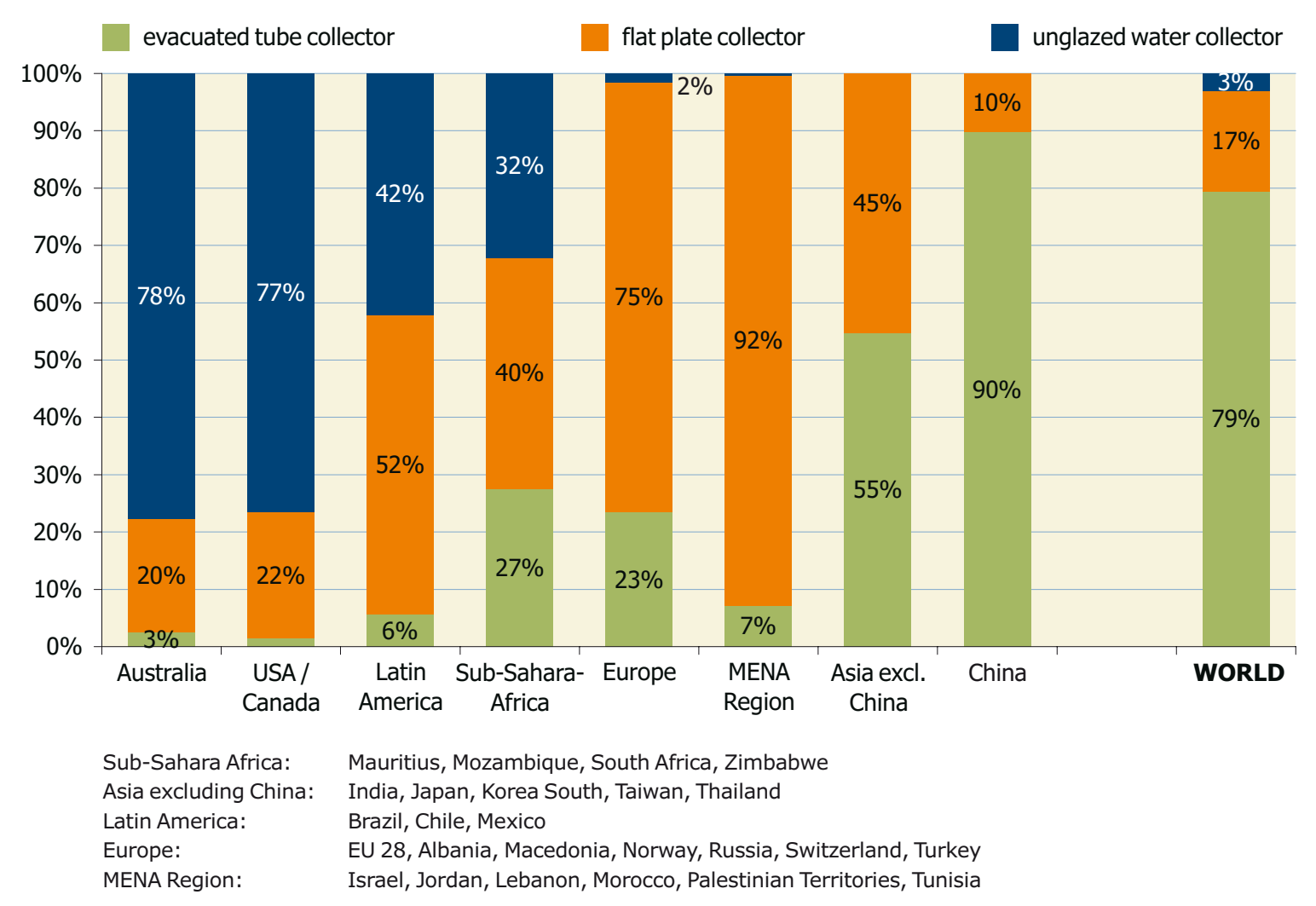

Figure 35: Distribution by type of solar thermal collector for the newly installed water collector capacity in 2013

\subsection{Distribution by type of system}

Worldwide, more than three quarters of all solar thermal systems installed are thermosiphon systems and the rest are pumped solar heating systems (Figure 36). Similar to the distribution by type of solar thermal collector in total numbers the Chinese market influenced the overall figures most, and in $201390 \%$ of the newly installed systems were estimated to be thermosiphon systems while pumped systems only accounted for 10\% (Figure 37).

In general, thermosiphon systems are more common in warm climates such as in Africa, South America, southern Europe and the MENA region. In these regions thermosiphon systems are more often equipped with flat plate collectors, while in China, the typical thermosiphon system for domestic hot water preparation is equipped with evacuated tubes. 


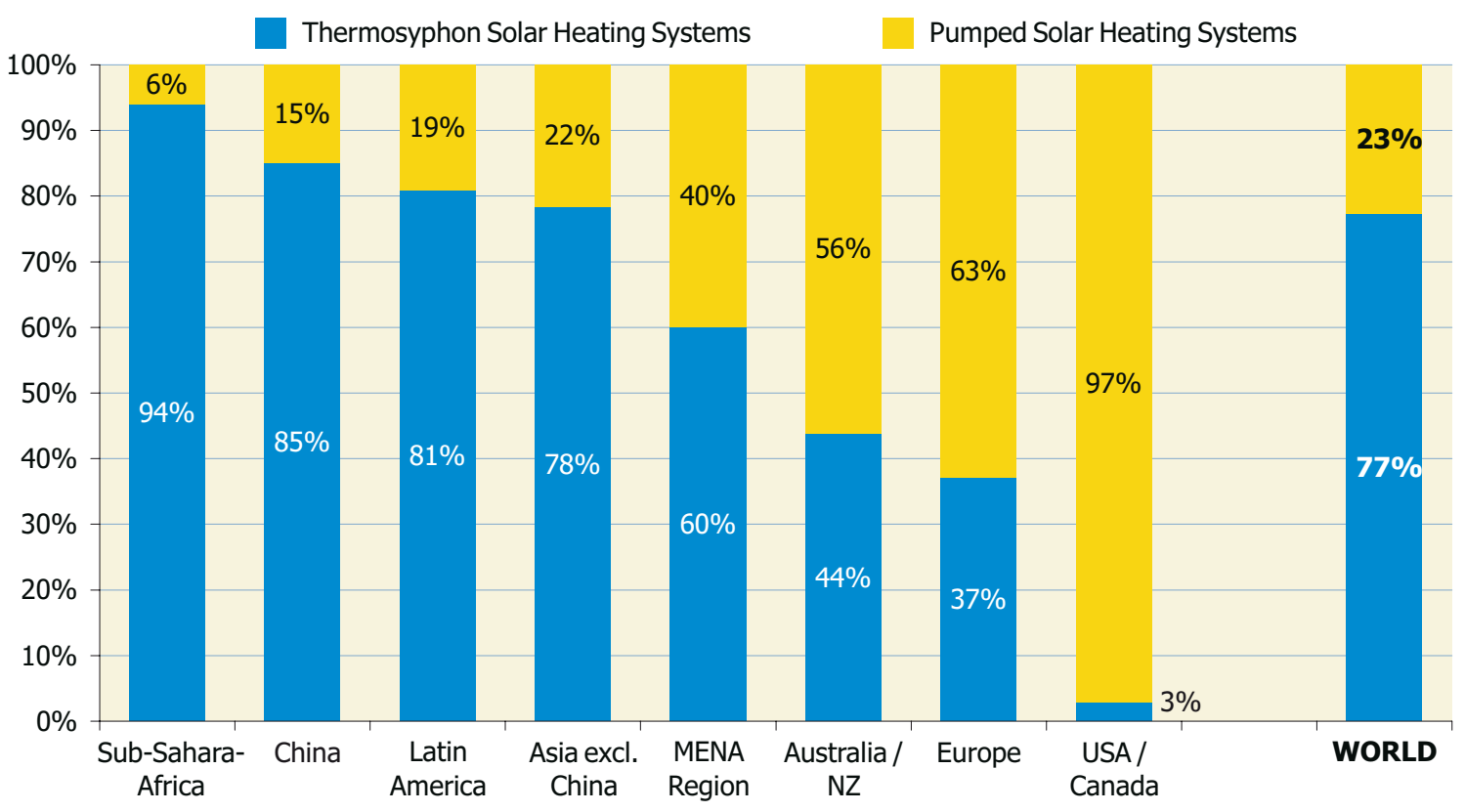

Figure 36: Distribution by type of system for the total installed glazed water collector capacity in operation by the end of 2013

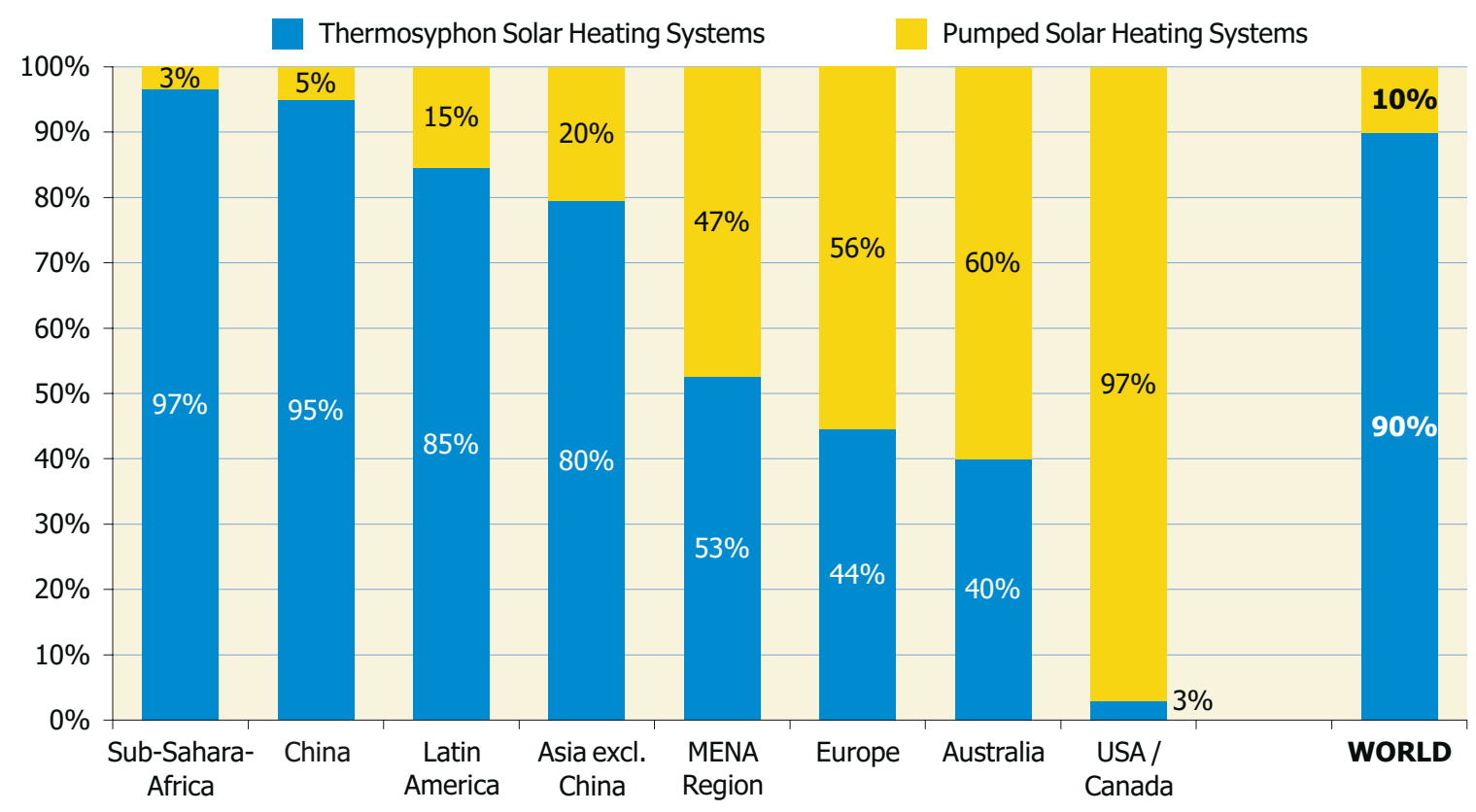

Sub-Sahara Africa: Asia excluding China: Latin America:

Europe:

MENA Region:
Mauritius, Mozambique, South Africa, Zimbabwe

India, Japan, Korea South, Taiwan, Thailand Brazil, Chile, Mexico

EU 28, Albania, Macedonia, Norway, Russia, Switzerland, Turkey Israel, Jordan, Lebanon, Morocco, Palestinian Territories, Tunisia

Figure 37: Distribution by type of system for the newly installed glazed water collector capacity in 2013 


\subsection{Distribution by kind of application}

The calculated number of water-based solar thermal systems in operation by the end of 2013 was about 111 million (Table 5). Out of these, 6\% were used for swimming pool heating, $80 \%$ were used for domestic hot water preparation in single family houses and $9 \%$ were attached to larger domestic hot water systems for multifamily houses, hotels, hospitals, schools, etc. Around 3\% of the worldwide installed capacity supplied heat for both domestic hot water and space heating (solar combi-systems). The remaining systems accounted for around $1 \%$ or 4.9 million square meters of solar thermal collectors and delivered heat to district heating networks, industrial processes or thermally driven solar cooling applications (Figure 38).

Compared to the cumulated installed capacity, the share of swimming pool heating was less for new installations ( $6 \%$ of total capacity and 3\% of newly installed capacity). A similar trend can be seen for domestic hot water systems in single family homes: $80 \%$ of total capacity in operation and $77 \%$ of new installations in 2013 make this kind of systems the most common application world-wide but with a slightly decreasing tendency.

By contrast the share of large-scale domestic hot water applications tended to increase ( $9 \%$ of total capacity and $17 \%$ of newly installed capacity). It can be assumed that this market segment took over some of the market shares from both swimming pool heating and domestic hot water systems in single family homes.

The share of solar combi-systems as well as other applications, such as solar district heating, solar process heat or solar cooling remained at a low level of 3-4\% and no real trend can be identified in a global context (Figure 39).

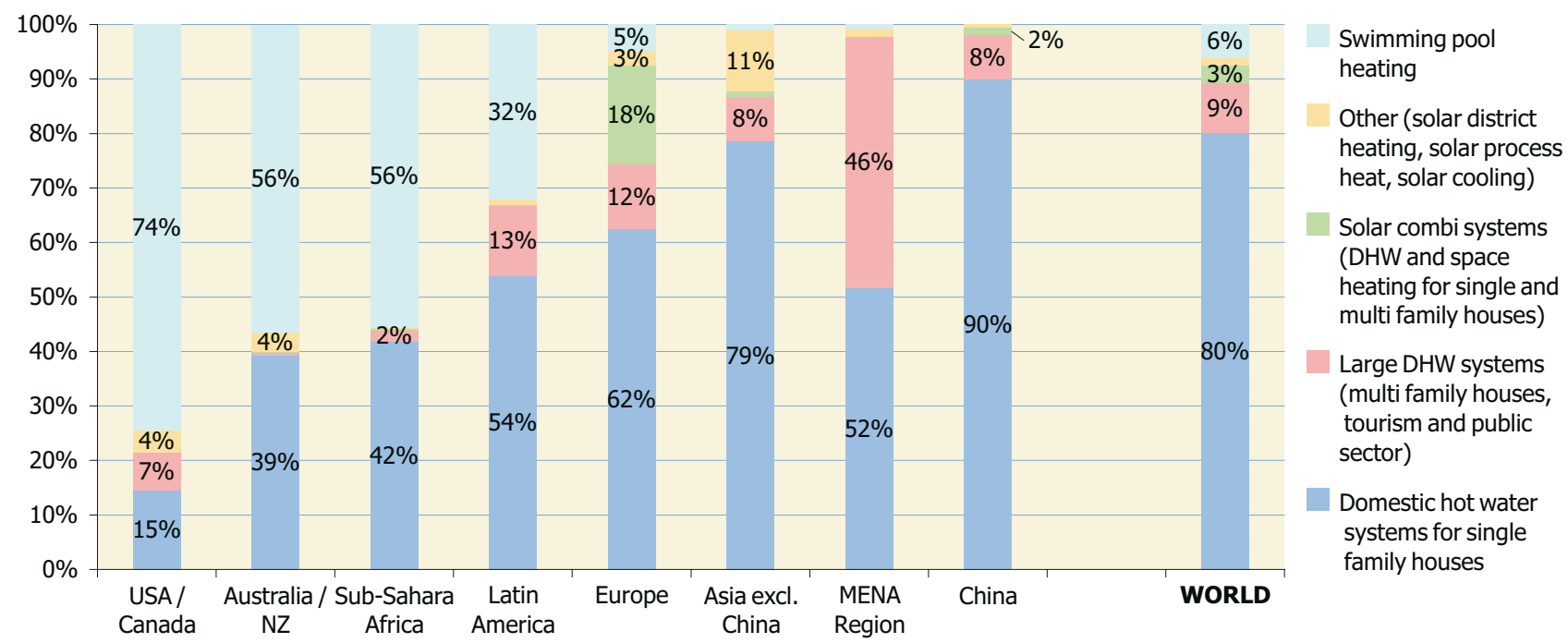

Sub-Sahara Africa: $\quad$ Mauritius, Mozambique, Namibia, South Africa, Zimbabwe

Asia excluding China: India, Japan, Korea South, Taiwan, Thailand

Latin America: Barbados, Brazil, Chile, Mexico, Uruguay

Europe: $\quad$ EU 28, Albania, Macedonia, Norway, Russia, Switzerland, Turkey

MENA Region: $\quad$ Israel, Jordan, Lebanon, Morocco, Palestinian Territories, Tunisia

Figure 38: Distribution of solar thermal systems by application for the total installed water collector capacity

by economic region in operation by the end of 2013 


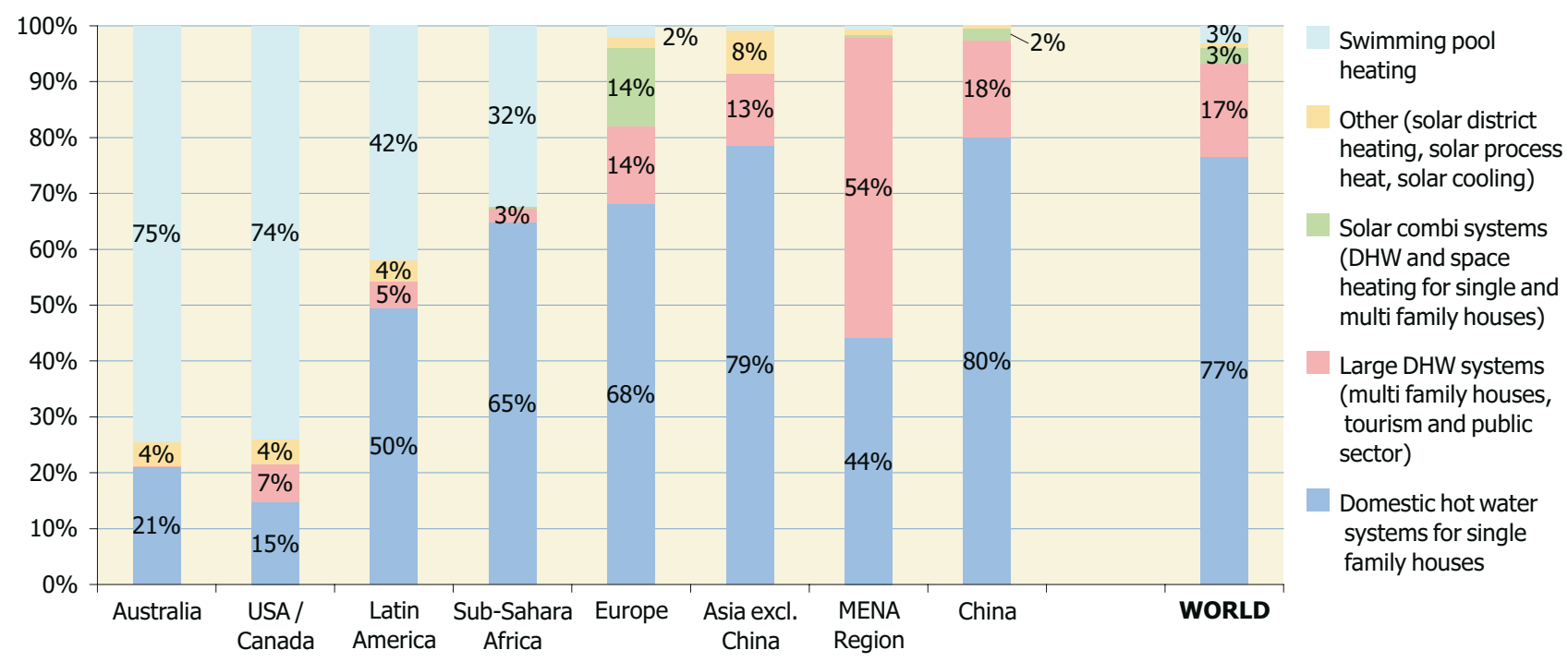

Sub-Sahara Africa:

Mauritius, Mozambique, South Africa, Zimbabwe

Asia excluding China:

India, Japan, Korea South, Taiwan, Thailand

Latin America:

Brazil, Chile, Mexico

Europe:

EU 28, Albania, Macedonia, Norway, Russia, Switzerland, Turkey

MENA Region:

Israel, Jordan, Lebanon, Morocco, Palestinian Territories, Tunisia

Figure 39: Distribution of solar thermal systems by application for the newly installed water collector capacity by economic region in 2013 


\section{Exceptional markets and applications for solar thermal systems}

\subsection{Overview of global megawatt-scale solar thermal applications}

Megawatt-scale solar supported district heating systems and solar heating and cooling applications in the commercial and industrial sector have gained increasing interest all over the world in recent years, and several ambitious projects have been successfully implemented.

Two of the largest solar thermal systems worldwide are located in Denmark and supply heat to district heating net-

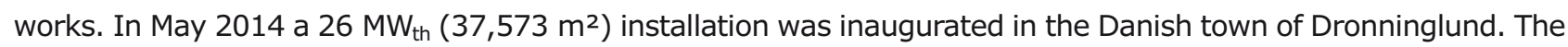
ground-mounted flat plate collector field is hydraulically connected to seasonal pit heat storage with a volume of $61,700 \mathrm{~m}^{3}$ and is designed to cover around $50 \%$ of the annual district heating demand of the 1,350 costumers connected in future 8,9 . The construction of an even larger solar district heating application with seasonal storage began later in 2014 in the Danish city of Vojens and commissioning is planned for mid-2015. This new world's largest solar thermal system with a thermal capacity of $37 \mathrm{MW}_{\text {th }}\left(52,491 \mathrm{~m}^{2}\right)$ is going to be connected to a huge seasonal pit heat storage with a volume of $203,000 \mathrm{~m}^{3}$. Together with an already existing $13 \mathrm{MW}_{\text {th }}\left(17,500 \mathrm{~m}^{2}\right)$ installation at Vojens district heating, a total solar thermal capacity of $50 \mathrm{MW}_{\text {th }}\left(69,991 \mathrm{~m}^{2}\right)$ will deliver $55-60 \%$ of the thermal energy demand of 2,000 households ${ }^{10,11}$.

In Riyadh, Saudi Arabia another large-scale solar district heating plant was commissioned in July 2011. The solar thermal plant with a total capacity of $25.4 \mathrm{MW}_{\text {th }}\left(36.305 \mathrm{~m}^{2}\right)$ is connected to a heating network for the supply of space heating and domestic hot water at a university campus ${ }^{12}$. Another successful solar supported heating network was implemented in Alberta, Canada. The Drake Landing Solar Community uses a $1.6 \mathrm{MW}_{\text {th }}\left(2.293 \mathrm{~m}^{2}\right)$ centralized solar thermal plant connected to a seasonal borehole thermal energy storage to supply more than $90 \%$ of the energy needed for space heating of 52 energy efficient single family homes ${ }^{13}, 14$.

Probably the two largest solar cooling applications worldwide are in Singapore and the USA. In August 2011 a solar cooling installation with a total capacity of $2.73 \mathrm{MW}_{\text {th }}\left(3,900 \mathrm{~m}^{2}\right)$ started operation at the United World College in Singapore. The roof mounted solar thermal collector field is hydraulically connected to a $1.76 \mathrm{MW}_{\text {th }}$ absorption chiller and supplies hot water and cooling to approximately 2,900 students who live and study at the newly created 76,000 $\mathrm{m}^{2}$ campus $^{15}$. The largest solar cooling application is located in Arizona, USA and was commissioned in May 2014. The installation covers a roof-mounted solar thermal collector field with a capacity of $3.4 \mathrm{MW}_{\text {th }}\left(4,865 \mathrm{~m}^{2}\right)$ that supplies heat to a single-effect lithium bromide absorption chiller with a cooling capacity of 1.75 MW16, 17 .

\footnotetext{
http://www.solarthermalworld.org/content/denmark-dronninglund-inaugurates-26-mwth-solar-district-heating-plant http://www.solarthermalworld.org/content/denmark-23-mwth-cover-55-heat-demand-1500-households http://www.solarthermalworld.org/content/denmark-37-mw-field-203000-m3-storage-underway http://www.arcon.dk/NY_Referencer.aspx

http://www.solarthermalworld.org/content/saudi-arabia-womens-university-solar-district-heating http://www.solarthermalworld.org/content/canada-district-heating-90-solar-fraction http://www.dlsc.ca/

http://www.solarthermalworld.org/content/singapore-second-largest-solar-cooling-installation-worldwide http://www.solarthermalworld.org/content/usa-largest-solar-cooling-system-worldwide http://www.solid.at/en/references/solar-cooling
} 
The world's largest solar process heat application was commissioned in Chile in June 2013. The installation with a thermal peak capacity of $27.5 \mathrm{MW}$ covers a total of $39,300 \mathrm{~m}^{2}$ of flat plate collector area connected to 4,000 $\mathrm{m}^{3}$ thermal energy storage. The solar thermal system is designed to cover $85 \%$ of the process heat demand needed to refine copper at the Gaby copper mine of state-owned mining company Codelco ${ }^{18}$.

In the USA, probably the largest solar thermal system is a solar process heat application that was dedicated in April 2012 in North Carolina. The $5.5 \mathrm{MW}_{\text {th }}\left(7,804 \mathrm{~m}^{2}\right)$ solar thermal system equipped with flat plate collectors supplies hot water to a turkey processing plant, lessening the use of propane gas ${ }^{19}$.

The largest solar process heat applications installed in China are connected to dyeing and weaving mill factories. A system with a thermal peak capacity of $9.1 \mathrm{MW}_{\text {th }}\left(13,000 \mathrm{~m}^{2}\right)$ was constructed in the province of Zhejiang and two other projects of $10.5 \mathrm{MW}_{\mathrm{th}}\left(15,000 \mathrm{~m}^{2}\right)$ have been commissioned in the neighboring province of Jiangsu.

More examples of solar process heat applications can be found at http://ship-plants.info/.

\subsection{Large-scale solar district heating and cooling applications in Europe}

In the Scandinavian countries of Denmark and Sweden, but also in Austria, Germany, Spain and Greece large-scale solar thermal applications connected to local or district heating grids have been in use since the early 1980 s.

By the end of 2014, 210 large-scale solar thermal systems $>350 \mathrm{~kW}_{\text {th }}\left(500 \mathrm{~m}^{2}\right)$ connected to heating networks and 17 systems connected to cooling networks were in operation in Europe. The total installed capacity of these systems equaled $551 \mathrm{MW}_{\mathrm{th}}\left(\approx 787,500 \mathrm{~m}^{2}\right)$.

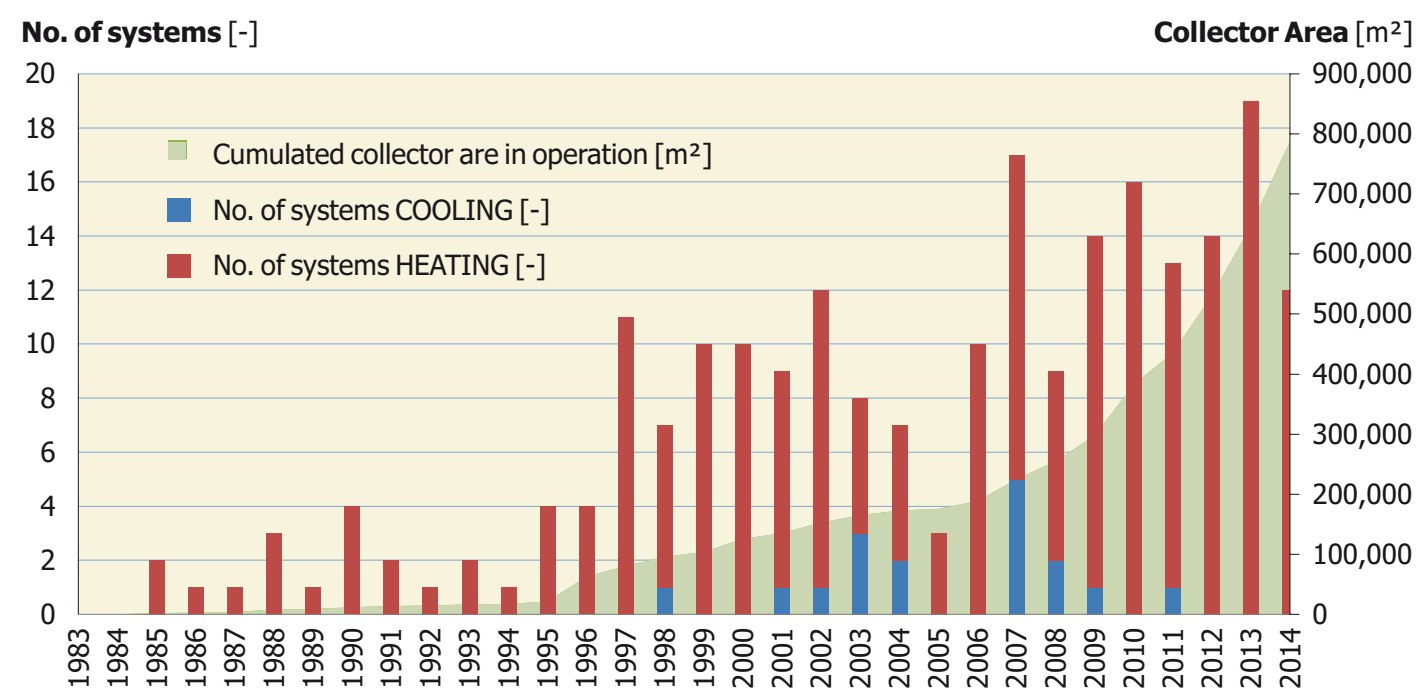

Figure 40: Solar district heating and cooling in Europe - annual achievements and cumulated area in operation by end of 2014 (Data source: Jan-Olof Dalenbäck - Chalmers University of Technology, SE) 
Denmark by far holds the leading position in Europe with both large-scale systems installed as well as capacity installed. By end of 2014 sixty-one solar district heating plants with a total installed capacity of $389 \mathrm{MW}_{\text {th }}\left(555,626 \mathrm{~m}^{2}\right)$ were in operation in Denmark. The average system size of these plants calculates to $6.4 \mathrm{MW}_{\text {th }}\left(9,100 \mathrm{~m}^{2}\right)$. Most of the Danish installations are ground mounted flat plate collector fields hydraulically connected to load-balancing storages in close distance to the district heating main distribution line. The largest plants in operation are located in Dronninglund (26.3 $\mathrm{MW}_{\text {th }} ; 37,573 \mathrm{~m}^{2}$ ) and Marstal $\left(23.3 \mathrm{MW}_{\text {th }} ; 33,300 \mathrm{~m}^{2}\right.$ ) and are equipped with seasonal pit heat storages and additional thermal or compression heat pumps for solar fractions of around $50 \%$. Even larger plants, such as the huge $50 \mathrm{MW}_{\text {th }}\left(70,000 \mathrm{~m}^{2}\right)$ installation in Vojens are currently under construction (see chapter 7.1) ${ }^{20}$.

In Europe and worldwide, Denmark is the only example for a mature and commercial solar district heating market. In several other countries smaller niche markets exist, such as in Austria where 25 systems $>500 \mathrm{~m}^{2}$ are installed to feed into district heating networks, smaller micro grids in urban quarters or local biomass heating networks. In Germany, several remarkable demonstration plants with seasonal storage were built and also from other countries such as Sweden (22 plants), Spain (16 plants), Greece, France, Poland (14 plants) and Switzerland (9 plants) interesting achievements are reported.

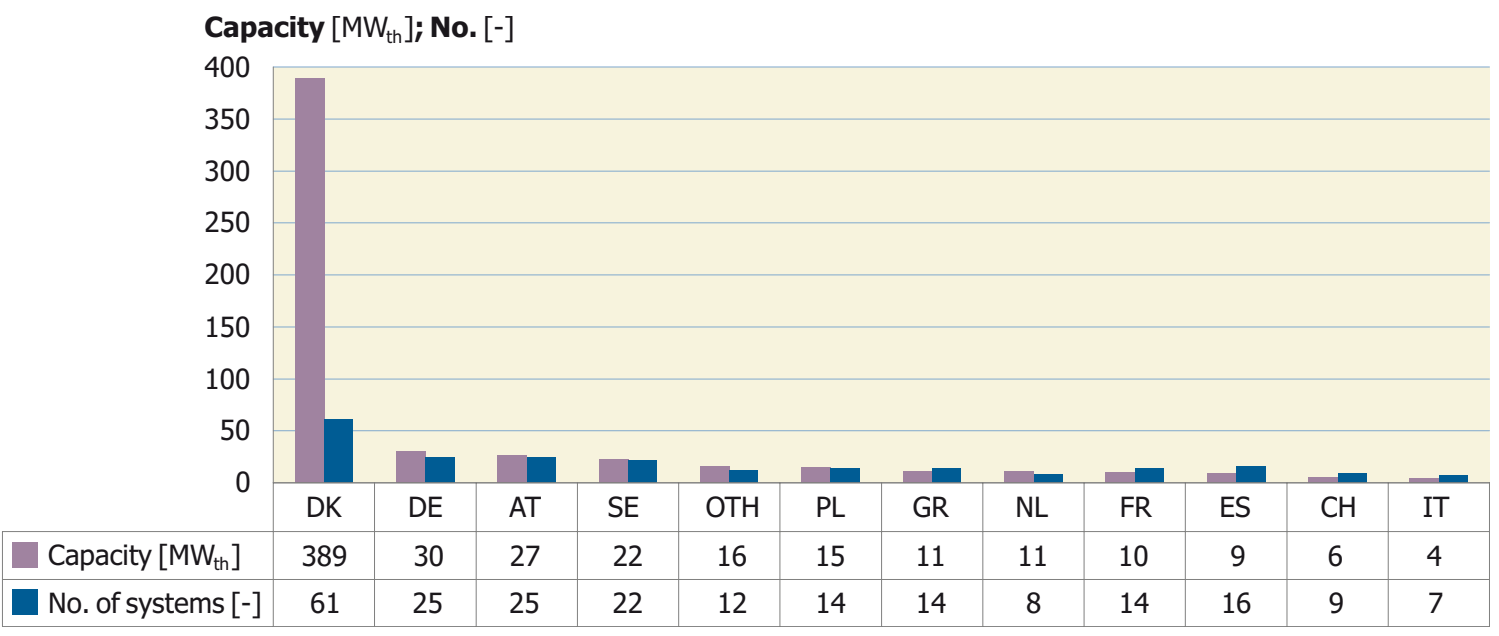

Figure 41: Solar district heating and cooling in Europe - capacities installed and No. of systems by end of 2014 (Data source: Jan-Olof Dalenbäck - Chalmers University of Technology, SE)

Large-scale solar cooling applications have been built in southern European countries with high cooling loads. In Italy (5 plants) and Spain (5 plants) several best practice examples exist.

The market for solar supported district heating networks in Denmark has been booming for several years and is driven by high taxes for fossil fuels and an energy supply system that is characterized by decentralization on the one hand and a high share of wind energy for electricity production on the other hand. This together with the liberalized market mechanisms for electricity in Europe and low solar thermal system prices for large-scale systems make solar thermal heat in Denmark even competitive against natural gas driven combined heat and power systems in many cases. Actual levelized costs for solar thermal generated heat in Denmark amount to $30-40 € / M W h$. More information about the (Danish) Solar District Heating success story in Europe can be found here: http://www.solar-district-heating.eu/. A database of techno-economic benchmark figures and monitoring data of several Danish best practice examples can be accessed here: http://www.solvarmedata.dk/index.asp?secid=228 


\subsection{Market for solar air conditioning and cooling applications}

Solar cooling applications convert the energy from the sun into cold by means of driving a thermal cooling machine.

By the end of 2014, an estimated 1,175 solar cooling systems were installed worldwide. The market showed a positive trend between 2004 and 2014, but the growth rates tended to decrease from $32 \%$ in 2007/2008 to $12 \%$ in $2013 / 2014$.

Approximately three quarters of the solar cooling installations worldwide are installed in Europe, most notably in Spain, Germany and Italy. The majority of the solar air conditioning and cooling applications installed is equipped with high performance flat plate or evacuated tube collectors. By contrast some examples for thermal cooling machines driven by concentrating solar thermal collectors (e.g. parabolic troughs or Fresnel collectors) were reported from India, Australia and Turkey ${ }^{21}$.

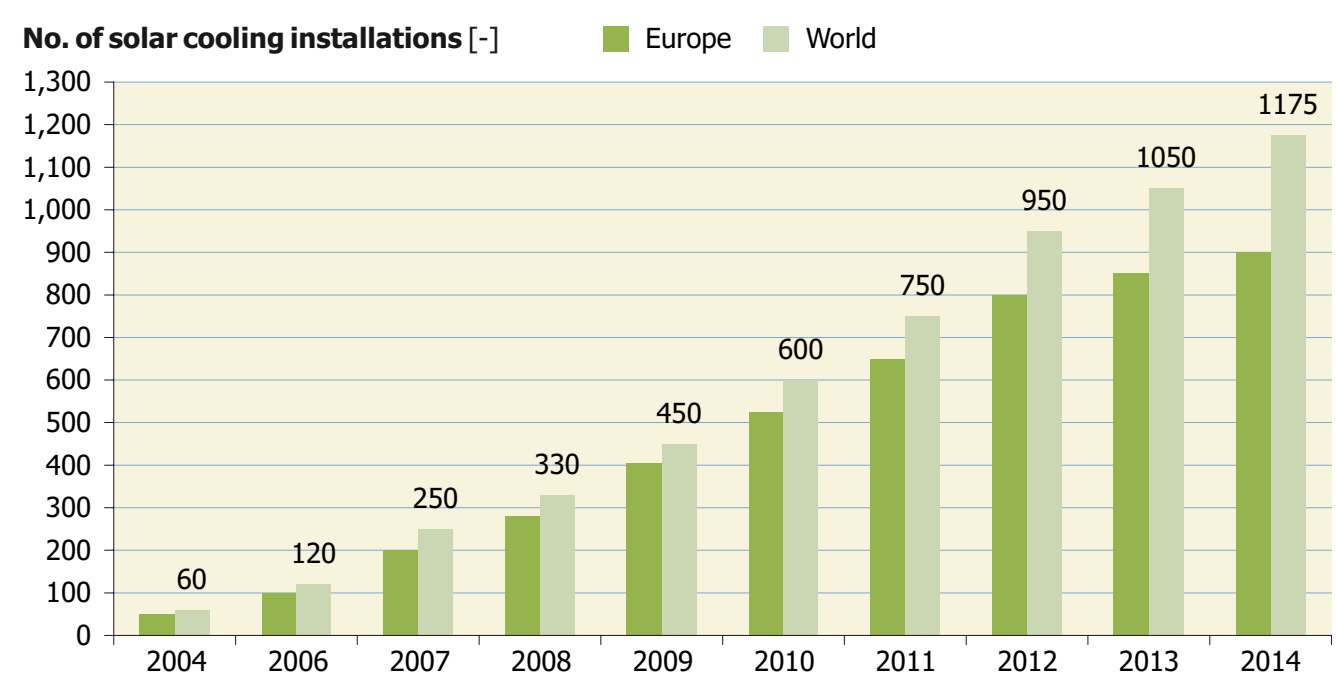

Figure 42: Market development 2004-2014 solar air conditioning and cooling systems in Europe and world-wide (Source: Climasol, EURAC, Fraunhofer ISE, Green Chiller, Rococo, Solem Consulting, Tecsol)

\subsection{Best practice examples of worldwide installed solar process heat applications}

A variety of industrial processes demand vast amounts of thermal energy, which makes the industrial sector a promising market for solar thermal applications. Depending on the temperature level of the needed heat, different types of solar thermal collectors are used-air collectors, flat plate and evacuated tube collectors for temperatures at or below $100^{\circ} \mathrm{C}$ to concentrating solar thermal collectors such as parabolic troughs, Fresnel collectors or Scheffler dishes for temperatures up to $400^{\circ} \mathrm{C}$.

Solar Heat for Industrial Processes (SHIP) is still a niche market, but a number of promising projects have been realized in the last couple of years ranging from small-scale demonstration plants to very large systems, such as the 
world's second largest solar thermal plant in Chile, which delivers heat for the leaching process at a copper mine (see section 7.1).

Currently, 151 SHIP applications are reported to be in operation all over the world with a cumulated installed capacity of around $100 \mathrm{MW}_{\text {th }}\left(143,226 \mathrm{~m}^{2}\right)$. Of these installations, 19 systems exceed $0.7 \mathrm{MW}_{\text {th }}\left(1,000 \mathrm{~m}^{2}\right)$ of thermal peak capacity, 31 systems have installed capacities of between 0.35 and $0.7 \mathrm{MW}_{\text {th }}\left(500-1,000 \mathrm{~m}^{2}\right)$ and 101 systems are below $0.35 \mathrm{MW}_{\text {th }}$.

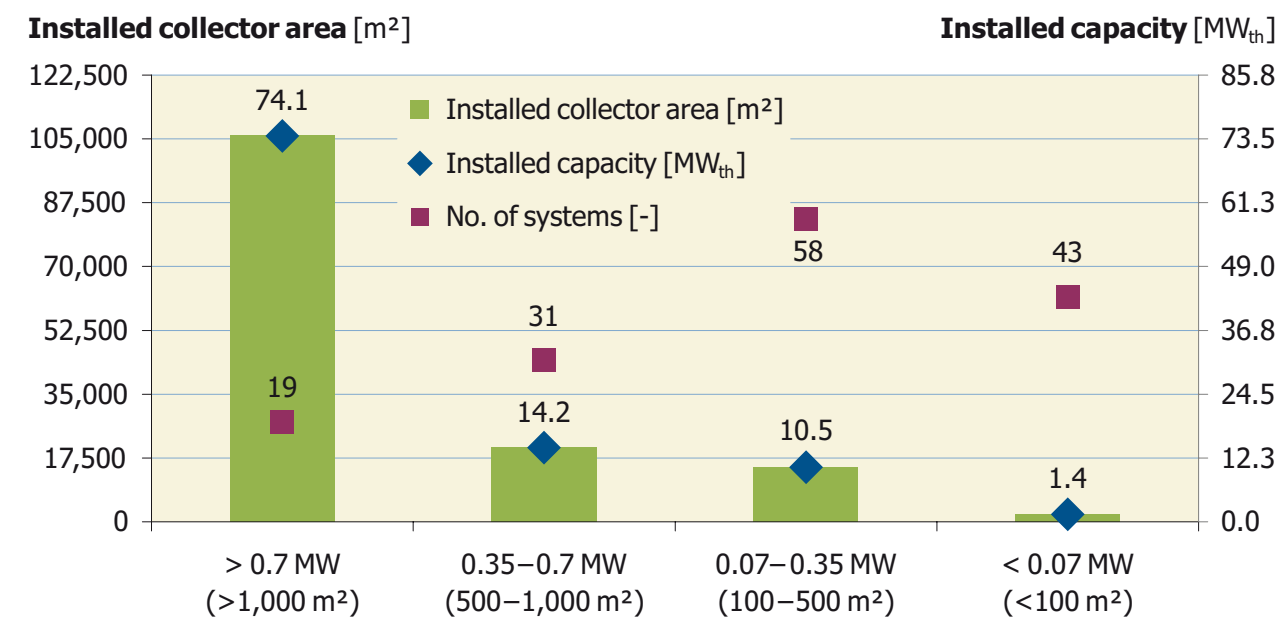

Figure 43: Global solar process heat applications in operation (Source: IEA SHC Task49/IV SHIP database)

Further information on the mentioned solar process heat applications in operation are collected in an online database that was created within the framework of IEA SHC Task 49/IV on "Solar Heat Integration in Industrial Processes"22.

The SHIP database can be accessed by private users and it is the intention to continuously add new and existing SHIP applications in order to spread knowledge about the possibilities offered by this technology. The database can be found at http://ship-plants.info/.

\subsection{Market for Solar Air Heating Systems}

Solar air heating is a solar thermal technology in which the energy from the sun heats air. In colder climates, space heating is usually the largest use of building energy and it is the air in the buildings that is heated. Space heating consumes much more energy than hot water in most buildings. Solar air heating systems can be building integrated and typically reduce between $20-30 \%$ of conventional energy used for heating buildings.

The air is generally taken off the top of the wall (since hot air rises) and the heated or pre-heated fresh air is then connected to fans and ducted into the building via the ventilation system.

Solar air heaters are also common in agricultural applications primarily for drying. 
Solar air heating systems have been used globally for the past 30 years by schools, municipalities, military, agricultural, commercial and industrial entities as well as in residential buildings. Wall mounted systems are common and take advantage of the lower winter sun angles and eliminate any snow accumulation typical of roof mounted systems. Storage of the heat is possible, but most solar air systems do not include storage to minimize costs.

Solar space heating with air collectors has not been common in Europe, likely due to the lack of a European test standard for air collectors, but in North America building integrated solar air collectors are the most popular form of solar thermal systems in the commercial, industrial and institutional markets due to their low cost and architectural integration into buildings. 


\section{Appendix}

\subsection{Methodological approach for the energy calculation}

In order to obtain the energy yield of solar thermal systems, the oil equivalent saved and the $\mathrm{CO}_{2}$ emissions avoided, the following procedure was used:

- Only water collectors were used in the calculations (unglazed water collectors, flat-plate collectors and evacuated tube collectors). Air collectors were not included.

- For each country, the cumulated water collector area was allocated to the following applications (based on available country market data):

- Solar thermal systems for swimming pool heating

- Solar domestic hot water systems for single-family houses,

- Solar domestic hot water systems for multifamily houses including the tourism sector as well as the public sector (to simplify the analysis solar district heating systems, solar process heat and solar cooling applications were also allocated here), and

- Solar combi systems for domestic hot water and space heating for single- and multi-family houses.

- Reference systems were defined for each country and for each type of application (pumped or thermosiphon solar thermal system).

- The number of systems per country was determined from the share of collector area for each application and the collector area defined for the reference system.

Apart from the reference applications and systems mentioned above, reference collectors and reference climates were determined. On the basis of these boundary conditions, simulations were performed with the simulation program T-Sol [T-Sol, Version 4.5 Expert, Valentin Energiesoftware, www.valentin-software.com] and gross solar yields for each country and each system were obtained. The gross solar yields refer to the solar collector heat output and do not include heat losses through transmission piping or storage heat losses 23 .

The amount of final energy saved is calculated from the gross solar yields considering a utilization rate of the auxiliary heating system of 0.8 . Final energy savings are expressed in tons of oil equivalent (toe): 1 toe $=11,630 \mathrm{kWh}$.

Finally, the $\mathrm{CO}_{2}$ emissions avoided by the different solar thermal applications are quoted as kilograms carbon dioxide equivalent $\left(\mathrm{kgCO}_{2} \mathrm{e}\right)$ per tons of oil equivalent: 1 toe $=3.233 \mathrm{t} \mathrm{CO}_{2} \mathrm{e}^{24}$

To obtain an exact statement about the $\mathrm{CO}_{2}$ emissions avoided, the substituted energy medium would have to be ascertained for each country. Since this could only be done in a very detailed survey, which goes beyond the scope of this report, the energy savings and the $\mathrm{CO}_{2}$ emissions avoided therefore relate to fuel oil. It is obvious that not all solar thermal systems just replace systems running on oil. This represents a simplification since gas, coal, biomass or electricity can be used as an energy source for the auxiliary heating system instead of oil. 
The following tables describe the key data of the reference systems in the different countries, the location of the reference climate used and the share of the total collector area in use for the respective application. Furthermore, a hydraulic scheme is shown for each reference system.

\subsubsection{Reference systems for swimming pool heating}

The information in Table 6 refers to the total capacity of water collectors in operation used for swimming pool heating as reported from each country by the end of 2013.

\begin{tabular}{|c|c|c|c|c|c|c|}
\hline Country* & $\begin{array}{l}\text { Reference } \\
\text { climate }\end{array}$ & $\begin{array}{l}\text { Horizontal } \\
\text { irradiation } \\
{\left[\mathrm{kWh} / \mathrm{m}^{2} \cdot \mathrm{a}\right]}\end{array}$ & $\begin{array}{c}\text { Total collector } \\
\text { area } \\
{\left[\mathrm{m}^{2}\right]}\end{array}$ & $\begin{array}{c}\text { Collector area } \\
\text { per system } \\
{\left[\mathrm{m}^{2}\right]}\end{array}$ & $\begin{array}{l}\text { Total number } \\
\text { of systems }\end{array}$ & $\begin{array}{c}\text { Specific solar } \\
\text { yield } \\
{\left[\mathrm{kWh} / \mathrm{m}^{2} \cdot \mathrm{a}\right]}\end{array}$ \\
\hline Australia & Sydney & 1,674 & $4,605,202$ & 34 & 135,447 & 466 \\
\hline Austria & Graz & 1,126 & 585,133 & 200 & 2,926 & 283 \\
\hline Barbados & Grantley Adams & 2,016 & 9,218 & 200 & 46 & 544 \\
\hline Belgium & Brussels & 971 & 34,145 & 200 & 171 & 262 \\
\hline Brazil & Brasília & 1,793 & $2,940,434$ & 200 & 14,702 & 375 \\
\hline Canada & Montreal & 1,351 & 540,737 & 200 & 2,704 & 386 \\
\hline Croatia & Zagreb & 1,212 & 10,190 & 200 & 51 & 327 \\
\hline Cyprus & Nicosia & 1,886 & 1,690 & 200 & 8 & 508 \\
\hline Czech Republic & Praha & 998 & 502,146 & 200 & 2,511 & 303 \\
\hline Denmark & Copenhagen & 989 & 24,278 & 200 & 121 & 295 \\
\hline Estonia & Tallin & 960 & 596 & 200 & 3 & 259 \\
\hline Finland & Helsinki & 948 & 3,654 & 200 & 18 & 256 \\
\hline France & Paris & 1,112 & 23,704 & 200 & 119 & 328 \\
\hline Germany & Würzburg & 1,091 & 609,058 & 200 & 3,045 & 314 \\
\hline Hungary & Budapest & 1,199 & 30,252 & 200 & 151 & 344 \\
\hline India & Neu-Delhi & 1,961 & 124,624 & 200 & 623 & 529 \\
\hline Israel & Jerusalem & 2,198 & 31,614 & 200 & 158 & 568 \\
\hline Italy & Bologna & 1,419 & 184,645 & 200 & 923 & 442 \\
\hline Jordan & Amman & 2,145 & 6,301 & 200 & 32 & 578 \\
\hline Latvia & Riga & 991 & 423 & 200 & 2 & 267 \\
\hline Lithuania & Vilnius & 1,001 & 574 & 200 & 3 & 270 \\
\hline Luxembourg & Luxembourg & 1,037 & 3,206 & 200 & 16 & 280 \\
\hline Macedonia & Skopje & 1,381 & 471 & 200 & 2 & 372 \\
\hline Malta & Luqa & 1,902 & 3,391 & 200 & 17 & 513 \\
\hline Mauritius & Port Louis & 1,920 & 8,058 & 200 & 40 & 518 \\
\hline Mexico & Mexico City & 1,706 & $1,022,890$ & 200 & 5,114 & 311 \\
\hline Morocco & Rabat & 2,000 & 29,050 & 200 & 145 & 539 \\
\hline Mozambique & Maputo & 1,910 & 29 & 200 & 0 & 515 \\
\hline Netherlands & Amsterdam & 999 & 424,377 & 200 & 2,122 & 272 \\
\hline New Zealand & Wellington & 1,401 & 11,175 & 200 & 56 & 378 \\
\hline Norway & Oslo & 971 & 1,781 & 200 & 9 & 316 \\
\hline Portugal & Lisbon & 1,686 & 1,809 & 200 & 9 & 421 \\
\hline Romania & Bucharest & 1,324 & 8,999 & 200 & 45 & 357 \\
\hline Russia & Moscow & 996 & 36 & 200 & 0 & 269 \\
\hline Slovakia & Bratislava & 1,214 & 10,514 & 200 & 53 & 327 \\
\hline South Africa & Johannesburg & 2,075 & 917,526 & 200 & 4,588 & 505 \\
\hline Spain & Madrid & 1,644 & 159,767 & 200 & 799 & 472 \\
\hline Sweden & Gothenburg & 934 & 129,844 & 200 & 649 & 295 \\
\hline Switzerland & Zürich & 1,094 & 231,507 & 200 & 1,158 & 277 \\
\hline Taiwan & Taipei & 1,372 & 12,365 & 200 & 62 & 319 \\
\hline Thailand & Bangkok & 1,765 & 9,563 & 200 & 48 & 476 \\
\hline United Kingdom & London & 943 & 52,071 & 200 & 260 & 254 \\
\hline United States & LA, Indianapolis & 1,646 & $17,882,073$ & 200 & 89,410 & 387 \\
\hline Uruguay & Montevideo & 1,534 & 880 & 200 & 4 & 414 \\
\hline Zimbabwe & Harare & 2,017 & 1,608 & 200 & 8 & 544 \\
\hline \multirow{3}{*}{ All other countries } & & 1,455 & $1,652,846$ & 200 & 8,264 & 392 \\
\hline & TOTAL & & $32,844,455$ & & 276,643 & \\
\hline & AVERAGE & 1,434 & & 119 & & 392 \\
\hline
\end{tabular}

* Countries not listed in this table did not report any share of collectors used for swimming pool heating.

Table 6: Solar thermal systems for swimming pool heating by end of 2013 
Figure 44 shows the hydraulic scheme of the swimming pool reference system as used for the simulations of the solar energy yields.

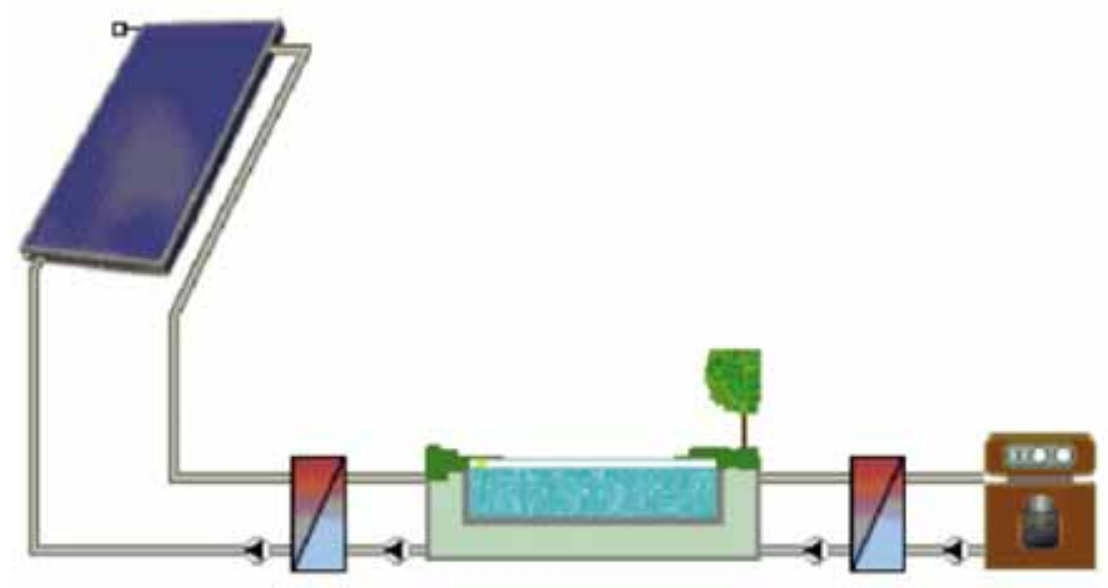

Figure 44: Hydraulic scheme of the swimming pool reference system

\subsubsection{Reference systems for domestic hot water preparation in single-family houses}

The information in Table 7 refers to the total capacity of water collectors in operation used for domestic hot water heating in single family houses at the end of 2013 as reported by each country. 


\begin{tabular}{|c|c|c|c|c|c|c|c|}
\hline Country & $\begin{array}{l}\text { Reference } \\
\text { climate }\end{array}$ & $\begin{array}{l}\text { Horizontal } \\
\text { irradiation } \\
{\left[\mathrm{kWh} / \mathrm{m}^{2} \cdot \mathrm{a}\right]}\end{array}$ & $\begin{array}{c}\text { Total collector } \\
\text { area (DHW-SFH) } \\
{\left[\mathrm{m}^{2}\right]}\end{array}$ & $\begin{array}{c}\text { Collector area } \\
\text { per system } \\
{\left[\mathrm{m}^{2}\right]}\end{array}$ & \begin{tabular}{|c|}
$\begin{array}{c}\text { Total number } \\
\text { of systems }\end{array}$ \\
\end{tabular} & $\begin{array}{c}\text { Specific solar } \\
\text { yield (DHW-SFH) } \\
{\left[\mathrm{kWh} / \mathrm{m}^{2} \cdot \mathrm{a}\right]}\end{array}$ & $\begin{array}{l}\text { Type of } \\
\text { system }\end{array}$ \\
\hline Albania & Tirana & 1,604 & 40,395 & 2.5 & 16,158 & 713 & TS \\
\hline Australia & Sydney & 1,674 & $3,088,855$ & 3.5 & 882,530 & 844 & PS \\
\hline Austria & Graz & 1,126 & $2,148,847$ & 6.0 & 358,141 & 451 & PS \\
\hline Barbados & Grantley Adams & 2,016 & 105,352 & 4.0 & 26,338 & 882 & TS \\
\hline Belgium & Brussels & 971 & 390,226 & 4.0 & 97,557 & 423 & PDS/PS \\
\hline Brazil & Brasília & 1,793 & $6,092,273$ & 4.0 & $1,523,068$ & 809 & TS \\
\hline Bulgaria & Sofia & 1,188 & 89,936 & 4.0 & 22,484 & 524 & PS \\
\hline Canada & Montreal & 1,351 & 35,575 & 6.0 & 5,929 & 556 & PS \\
\hline Chile & Santiago de Chile & 1,753 & 64,082 & 4.0 & 16,020 & 771 & PS \\
\hline China & Shanghai & 1,282 & $337,194,000$ & 4.0 & $84,298,500$ & 592 & TS \\
\hline Croatia & Zagreb & 1,212 & 116,452 & 4.0 & 29,113 & 539 & PS \\
\hline Cyprus & Nicosia & 1,886 & 607,654 & 4.0 & 151,914 & 912 & TS \\
\hline Czech Republic & Praha & 998 & 202,024 & 4.7 & 42,984 & 385 & PS \\
\hline Denmark & Copenhagen & 989 & 331,068 & 4.0 & 82,767 & 454 & PS \\
\hline Estonia & Tallin & 960 & 6,816 & 4.0 & 1,704 & 432 & PS \\
\hline Finland & Helsinki & 948 & 41,762 & 4.0 & 10,440 & 441 & PS \\
\hline France & Paris & 1,112 & 948,160 & 3.2 & 296,300 & 496 & PS \\
\hline Germany & Würzburg & 1,091 & $7,607,303$ & 6.0 & $1,267,884$ & 424 & PS \\
\hline Greece & Athens & 1,585 & $4,023,751$ & 2.5 & $1,609,500$ & 772 & TS \\
\hline Hungary & Budapest & 1,199 & 151,260 & 6.0 & 25,210 & 473 & PS \\
\hline India & Neu-Delhi & 1,961 & $4,361,840$ & 4.0 & $1,090,460$ & 882 & TS \\
\hline Ireland & Dublin & 949 & 249,857 & 4.0 & 62,464 & 423 & PS \\
\hline Israel & Jerusalem & 2,198 & 823,700 & 3.0 & 274,567 & 1,024 & TS \\
\hline Italy & Bologna & 1,419 & $2,289,595$ & 4.0 & 572,399 & 661 & PS \\
\hline Japan & Tokyo & 1,175 & $3,935,866$ & 4.0 & 983,967 & 586 & TS \\
\hline Jordan & Amman & 2,145 & 948,776 & 4.6 & 206,256 & 986 & TS \\
\hline Korea, South & Seoul & 1,161 & 951,788 & 4.0 & 237,947 & 525 & PS \\
\hline Latvia & Riga & 991 & 4,832 & 4.0 & 1,208 & 462 & PS \\
\hline Lebanon & Beirut & 1,935 & 213,180 & 4.0 & 53,295 & 860 & TS \\
\hline Lithuania & Vilnius & 1,001 & 6,560 & 4.0 & 1,640 & 450 & PS \\
\hline Luxembourg & Luxembourg & 1,037 & 36,640 & 4.0 & 9,160 & 450 & PS \\
\hline Macedonia & Skopje & 1,381 & 41,946 & 4.0 & 10,486 & 627 & PS \\
\hline Malta & Luqa & 1,902 & 38,758 & 4.0 & 9,690 & 868 & PS \\
\hline Mauritius & Port Louis & 1,920 & 92,090 & 1.5 & 61,394 & 854 & TS \\
\hline Mexico & Mexico City & 1,706 & 412,772 & 4.0 & 103,193 & 718 & PS \\
\hline Morocco & Rabat & 2,000 & 332,000 & 4.0 & 83,000 & 889 & TS \\
\hline Mozambique & Maputo & 1,910 & 332 & 4.0 & 83 & 849 & TS \\
\hline Namibia & Windhoek & 2,363 & 9,903 & 4.0 & 2,476 & 1,032 & TS \\
\hline Netherlands & Amsterdam & 999 & 350,886 & 2.8 & 125,316 & 433 & PDS/PS \\
\hline New Zealand & Wellington & 1,401 & 127,716 & 4.0 & 31,929 & 647 & PS \\
\hline Norway & Oslo & 971 & 1,227 & 8.0 & 153 & 430 & PS \\
\hline Palestinian Territ. & & 2,198 & $1,464,300$ & 1.5 & 976,200 & 977 & TS \\
\hline Poland & Warsaw & 1,024 & $1,039,500$ & 6.0 & 173,250 & 397 & PS \\
\hline Portugal & Lisbon & 1,686 & 664,902 & 4.0 & 166,226 & 804 & PS \\
\hline Romania & Bucharest & 1,324 & 102,840 & 4.0 & 25,710 & 594 & PS \\
\hline Russia & Moscow & 996 & 1,872 & 4.0 & 468 & 443 & PS \\
\hline Slovakia & Bratislava & 1,214 & 120,160 & 6.0 & 20,027 & 481 & PS \\
\hline Slovenia & Ljubjana & 1,115 & 155,044 & 6.0 & 25,841 & 424 & PS \\
\hline South Africa & Johannesburg & 2,075 & 576,429 & 4.0 & 144,107 & 1,009 & TS \\
\hline Spain & Madrid & 1,644 & $1,278,136$ & 4.0 & 319,534 & 766 & PS \\
\hline Sweden & Gothenburg & 934 & 34,504 & 4.0 & 8,626 & 383 & PS \\
\hline Switzerland & Zürich & 1,094 & 772,800 & 5.7 & 135,579 & 426 & PS \\
\hline Taiwan & Taipei & 1,372 & $1,451,345$ & 4.8 & 302,363 & 616 & TS \\
\hline Thailand & Bangkok & 1,765 & 109,289 & 4.0 & 27,322 & 854 & TS \\
\hline Tunisia & Tunis & 1,808 & 690,840 & 2.8 & 246,728 & 902 & TS \\
\hline Turkey & Antalya & 1,795 & $14,416,696$ & 4.0 & $3,604,174$ & 910 & TS \\
\hline United Kingdom & London & 943 & 595,098 & 4.0 & 148,775 & 415 & PS \\
\hline United States & LA, Indianapolis & 1,646 & $3,576,415$ & 6.0 & 596,069 & 646 & PS \\
\hline Uruguay & Montevideo & 1,534 & 10,057 & 4.0 & 2,514 & 682 & TS \\
\hline & Harare & 2,017 & 18,382 & 4.0 & 4,596 & 854 & TS \\
\hline \multirow{3}{*}{ All other countries } & & 1,383 & $21,345,649$ & 4.0 & $5,336,412$ & 615 & TS/PS \\
\hline & TOTAL & & $426,940,313$ & & $106,950,145$ & & \\
\hline & AVERAGE & 1,456 & & 4.0 & & 615 & \\
\hline
\end{tabular}

DHW-SFH: domestic hot water systems for single-family houses

$\begin{array}{ll}\text { PS } & \text { pumped system } \\ \text { TS } & \text { thermosiphon system } \\ \text { PDS } & \text { pumped drain back system }\end{array}$

Table 7: Solar thermal systems for domestic hot water heating in single family houses by the end of 2013 
Figure $\mathbf{4 5}$ shows the hydraulic scheme used for the energy calculation for all pumped solar thermal systems and Figure 46 refers to the thermosiphon systems.

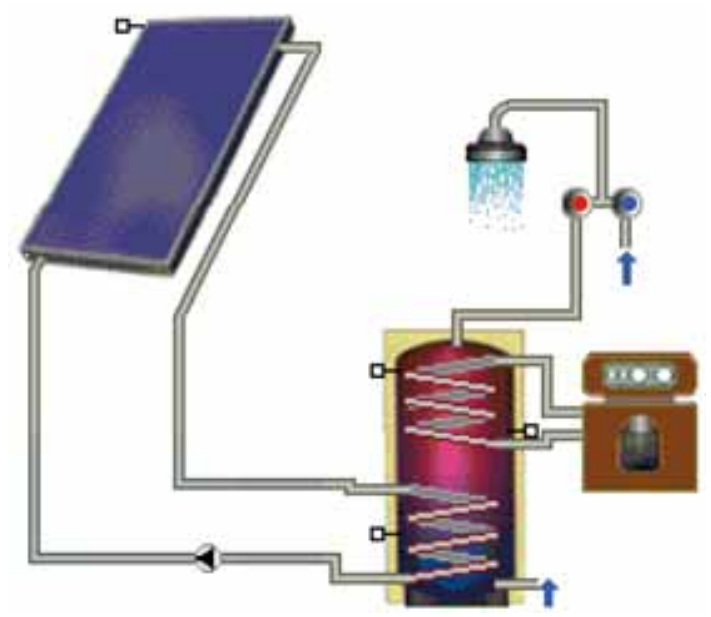

Figure 45: Hydraulic scheme of the domestic hot water pumped reference system for single family houses

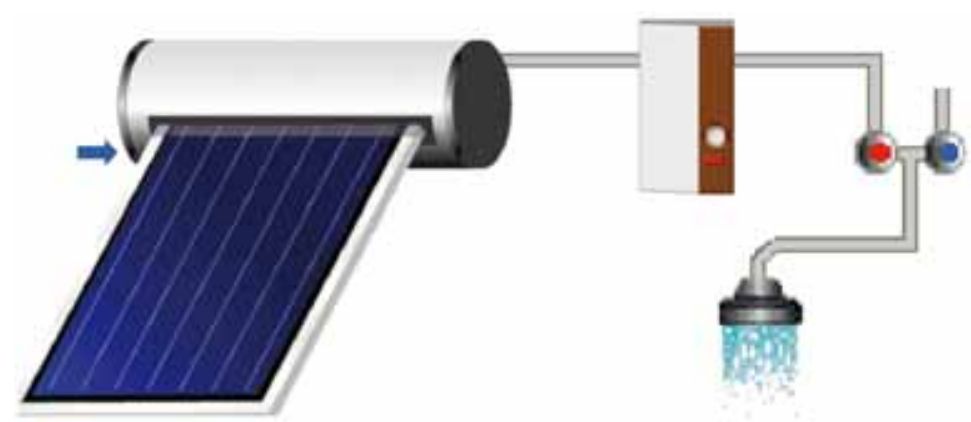

Figure 46: Hydraulic scheme of the domestic hot water thermosiphon reference system for single family houses

For the Chinese thermosiphon systems the reference system above was used, but instead of a flat plate collector as shown in Figure 46 a representative Chinese vacuum tube collector was used for the simulation.

\subsubsection{Reference systems for domestic hot water preparation in multifamily houses}

The information in Table 8 refers to the total capacity of water collectors in operation used for domestic hot water heating in multifamily houses at the end of 2013 as reported by each country. 


\begin{tabular}{|c|c|c|c|c|c|c|}
\hline Country & $\begin{array}{l}\text { Reference } \\
\text { climate }\end{array}$ & $\begin{array}{l}\text { Horizontal } \\
\text { irradiation } \\
{\left[\mathrm{kWh} / \mathrm{m}^{2} \cdot \mathrm{a}\right]}\end{array}$ & $\begin{array}{c}\text { Total collector } \\
\text { area (DHW-MFH) } \\
{\left[\mathrm{m}^{2}\right]}\end{array}$ & $\begin{array}{c}\text { Collector area } \\
\text { per system } \\
{\left[\mathrm{m}^{2}\right]}\end{array}$ & $\begin{array}{l}\text { Total number } \\
\text { of systems }\end{array}$ & $\begin{array}{c}\text { Specific solar } \\
\text { yield (DHW-MFH) } \\
{\left[\mathrm{kWh} / \mathrm{m}^{2} \cdot \mathrm{a}\right]}\end{array}$ \\
\hline Albania & Tirana & 1,604 & 101,490 & 50.0 & 2,030 & 694 \\
\hline Australia & Sydney & 1,674 & 328,943 & 50.0 & 6,579 & 725 \\
\hline Austria & Graz & 1,126 & 400,787 & 50.0 & 8,016 & 505 \\
\hline Barbados & Grantley Adams & 2,016 & 13,169 & 50.0 & 263 & 842 \\
\hline Belgium & Brussels & 971 & 48,778 & 50.0 & 976 & 405 \\
\hline Brazil & Brasília & 1,793 & 576,556 & 50.0 & 11,531 & 658 \\
\hline Bulgaria & Sofia & 1,188 & 36,264 & 50.0 & 725 & 515 \\
\hline Canada & Montreal & 1,351 & 313,058 & 50.0 & 6,261 & 621 \\
\hline Chile & Santiago de Chile & 1,753 & 75,227 & 50.0 & 1,505 & 733 \\
\hline China & Shanghai & 1,282 & $31,846,100$ & 50.0 & 636,922 & 502 \\
\hline Croatia & Zagreb & 1,212 & 14,557 & 50.0 & 291 & 506 \\
\hline Cyprus & Nicosia & 1,886 & 80,415 & 50.0 & 1,608 & 750 \\
\hline Czech Republic & Praha & 998 & 95,184 & 42.4 & 2,245 & 436 \\
\hline Denmark & Copenhagen & 989 & 422,136 & 50.0 & 8,443 & 414 \\
\hline Estonia & Tallin & 960 & 852 & 50.0 & 17 & 401 \\
\hline Finland & Helsinki & 948 & 5,220 & 50.0 & 104 & 396 \\
\hline France & Paris & 1,112 & $1,253,941$ & 20.0 & 62,697 & 489 \\
\hline Germany & Würzburg & 1,091 & $2,062,424$ & 50.0 & 41,248 & 472 \\
\hline Greece & Athens & 1,585 & 150,421 & 50.0 & 3,008 & 642 \\
\hline Hungary & Budapest & 1,199 & 18,908 & 50.0 & 378 & 522 \\
\hline India & Neu-Delhi & 1,961 & $1,744,736$ & 50.0 & 34,895 & 749 \\
\hline Ireland & Dublin & 949 & 8,329 & 50.0 & 167 & 425 \\
\hline Israel & Jerusalem & 2,198 & $3,294,801$ & 3.0 & $1,098,267$ & 919 \\
\hline Italy & Bologna & 1,419 & 664,721 & 50.0 & 13,294 & 593 \\
\hline Japan & Tokyo & 1,175 & 4,074 & 50.0 & 81 & 516 \\
\hline Jordan & Amman & 2,145 & 237,194 & 50.0 & 4,744 & 801 \\
\hline Korea, South & Seoul & 1,161 & 810,782 & 50.0 & 16,216 & 458 \\
\hline Latvia & Riga & 991 & 604 & 50.0 & 12 & 414 \\
\hline Lebanon & Beirut & 1,935 & 347,820 & 50.0 & 6,956 & 809 \\
\hline Lithuania & Vilnius & 1,001 & 820 & 50.0 & 16 & 418 \\
\hline Luxembourg & Luxembourg & 1,037 & 4,580 & 50.0 & 92 & 433 \\
\hline Macedonia & Skopje & 1,381 & 4,242 & 50.0 & 85 & 577 \\
\hline Malta & Luqa & 1,902 & 4,845 & 50.0 & 97 & 794 \\
\hline Mauritius & Port Louis & 1,920 & 11,511 & 50.0 & 230 & 801 \\
\hline Mexico & Mexico City & 1,706 & $1,061,415$ & 50.0 & 21,228 & 713 \\
\hline Morocco & Rabat & 2,000 & 41,500 & 50.0 & 830 & 835 \\
\hline Mozambique & Maputo & 1,910 & 42 & 50.0 & 1 & 797 \\
\hline Namibia & Windhoek & 2,363 & 12,103 & 50.0 & 242 & 814 \\
\hline Netherlands & Amsterdam & 999 & 82,295 & 50.0 & 1,646 & 418 \\
\hline New Zealand & Wellington & 1,401 & 15,965 & 50.0 & 319 & 585 \\
\hline Norway & Oslo & 971 & 16,305 & 50.0 & 326 & 406 \\
\hline Palestinian Territ. & & 2,198 & 162,700 & 50.0 & 3,254 & 917 \\
\hline Poland & Warsaw & 1,024 & 371,250 & 50.0 & 7,425 & 447 \\
\hline Portugal & Lisbon & 1,686 & 224,348 & 40.0 & 5,609 & 705 \\
\hline Romania & Bucharest & 1,324 & 12,855 & 50.0 & 257 & 553 \\
\hline Russia & Moscow & 996 & 15,649 & 50.0 & 313 & 416 \\
\hline Slovakia & Bratislava & 1,214 & 15,020 & 50.0 & 300 & 507 \\
\hline Slovenia & Ljubjana & 1,115 & 3,736 & 50.0 & 75 & 477 \\
\hline South Africa & Johannesburg & 2,075 & 12,656 & 50.0 & 253 & 867 \\
\hline Spain & Madrid & 1,644 & $1,501,809$ & 50.0 & 30,036 & 676 \\
\hline Sweden & Gothenburg & 934 & 45,854 & 50.0 & 917 & 430 \\
\hline Switzerland & Zürich & 1,094 & 92,275 & 20.0 & 4,614 & 457 \\
\hline Taiwan & Taipei & 1,372 & 81,918 & 33.8 & 2,424 & 518 \\
\hline Thailand & Bangkok & 1,765 & 13,661 & 50.0 & 273 & 737 \\
\hline Tunisia & Tunis & 1,808 & 15,540 & 50.0 & 311 & 756 \\
\hline Turkey & Antalya & 1,795 & $1,253,626$ & 50.0 & 25,073 & 750 \\
\hline United Kingdom & London & 943 & 74,387 & 50.0 & 1,488 & 393 \\
\hline United States & LA, Indianapolis & 1,646 & $2,384,276$ & 50.0 & 47,686 & 688 \\
\hline Uruguay & Montevideo & 1,534 & 1,257 & 50.0 & 25 & 640 \\
\hline & Harare & 2,017 & 2,298 & 50.0 & 46 & 842 \\
\hline \multirow{3}{*}{ All other countries } & & 1,362 & $2,758,148$ & 50.0 & 55,163 & 569 \\
\hline & TOTAL & & $55,256,376$ & & $2,180,133$ & \\
\hline & AVERAGE & 1,456 & & 25.3 & & 569 \\
\hline
\end{tabular}

DHW-MFH: domestic hot water systems for multifamily houses

PS: $\quad$ pumped system

Table 8: Solar thermal systems for domestic hot water heating in multifamily houses by end of 2013 


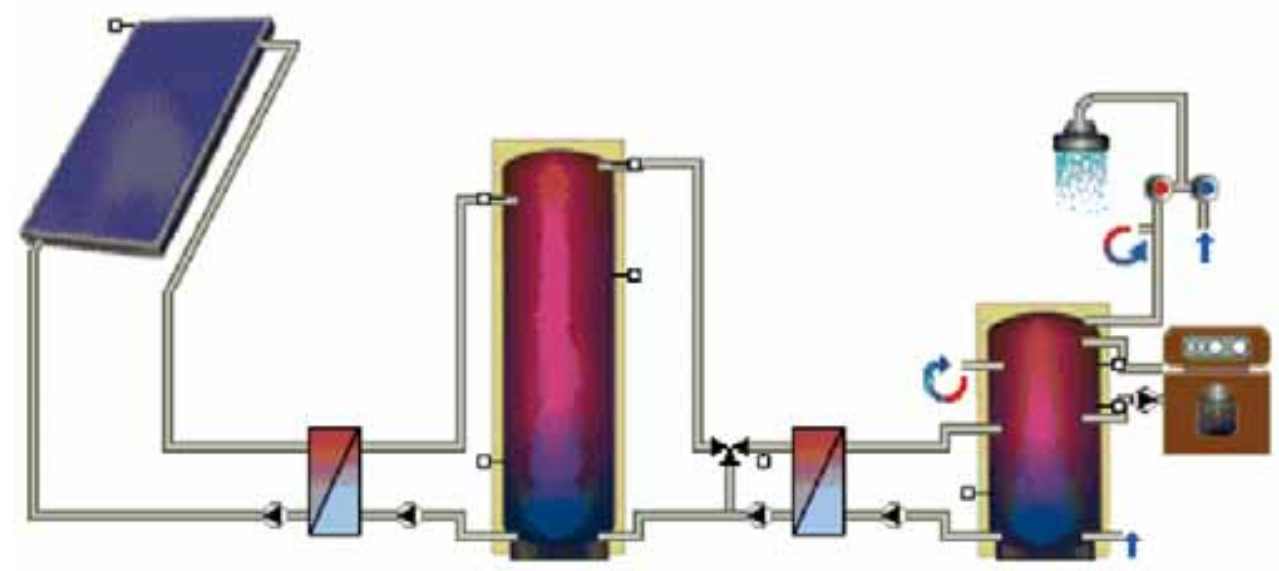

Figure 47: Hydraulic scheme of the domestic hot water pumped reference system for multifamily houses

Figure $\mathbf{4 7}$ shows the hydraulic scheme of domestic hot water reference system for multifamily houses as used for the simulations of the solar energy yields. As opposed to small-scale domestic hot water systems, all large-scale systems are assumed to be pumped solar thermal systems.

\subsubsection{Reference systems for domestic hot water preparation and space heating in single and multifamily houses (solar combi-systems)}

The information in Table 9 refers to the total capacity of water collectors in operation used for domestic hot water heating in multifamily houses at the end of 2013 as reported by each country. 


\begin{tabular}{|c|c|c|c|c|c|c|}
\hline Country & $\begin{array}{l}\text { Reference } \\
\text { climate }\end{array}$ & $\begin{array}{l}\text { Horizontal } \\
\text { irradiation } \\
{\left[\mathrm{kWh} / \mathrm{m}^{2} \cdot \mathrm{a}\right]}\end{array}$ & $\begin{array}{l}\text { Total collector } \\
\text { area (Combi } \\
\text { system) }\left[\mathrm{m}^{2}\right]\end{array}$ & $\begin{array}{c}\text { Collector area } \\
\text { per system } \\
{\left[\mathrm{m}^{2}\right]}\end{array}$ & $\begin{array}{l}\text { Total number } \\
\text { of systems }\end{array}$ & $\begin{array}{c}\text { Spec. solar yield } \\
\text { (Combi system) } \\
{\left[\mathrm{kWh} / \mathrm{m}^{2} \cdot \mathrm{a}\right]}\end{array}$ \\
\hline Austria & Graz & 1,126 & $2,027,032$ & 14.0 & 144,788 & 369 \\
\hline Barbados & Grantley Adams & 2,016 & 3,951 & 12.0 & 329 & 709 \\
\hline Belgium & Brussels & 971 & 14,633 & 12.0 & 1,219 & 342 \\
\hline China & Shanghai & 1,282 & $5,619,900$ & 12.0 & 468,325 & 388 \\
\hline Croatia & Zagreb & 1,212 & 4,367 & 12.0 & 364 & 426 \\
\hline Cyprus & Nicosia & 1,886 & 11,188 & 12.0 & 932 & 663 \\
\hline Czech Republic & Praha & 998 & 171,915 & 8.4 & 20,466 & 351 \\
\hline Denmark & Copenhagen & 989 & 7,608 & 12.0 & 634 & 348 \\
\hline Estonia & Tallin & 960 & 256 & 12.0 & 21 & 338 \\
\hline Finland & Helsinki & 948 & 1,566 & 12.0 & 131 & 334 \\
\hline France & Paris & 1,112 & 144,594 & 11.0 & 13,145 & 370 \\
\hline Germany & Würzburg & 1,091 & $7,235,390$ & 12.0 & 602,949 & 378 \\
\hline Greece & Athens & 1,585 & 4,178 & 12.0 & 348 & 558 \\
\hline Hungary & Budapest & 1,199 & 51,681 & 15.0 & 3,445 & 422 \\
\hline Ireland & Dublin & 949 & 19,433 & 12.0 & 1,619 & 364 \\
\hline Italy & Bologna & 1,419 & 553,934 & 12.0 & 46,161 & 499 \\
\hline Japan & Tokyo & 1,175 & 134,455 & 12.0 & 11,205 & 414 \\
\hline Latvia & Riga & 991 & 181 & 12.0 & 15 & 349 \\
\hline Lithuania & Vilnius & 1,001 & 246 & 12.0 & 21 & 352 \\
\hline Luxembourg & Luxembourg & 1,037 & 1,374 & 12.0 & 115 & 365 \\
\hline Macedonia & Skopje & 1,381 & 471 & 12.0 & 39 & 486 \\
\hline Malta & Luqa & 1,902 & 1,453 & 12.0 & 121 & 669 \\
\hline Mauritius & Port Louis & 1,920 & 3,453 & 12.0 & 288 & 676 \\
\hline Morocco & Rabat & 2,000 & 12,450 & 12.0 & 1,038 & 704 \\
\hline Mozambique & Maputo & 1,910 & 12 & 12.0 & 1 & 672 \\
\hline Netherlands & Amsterdam & 999 & 22,892 & 6.0 & 3,815 & 352 \\
\hline New Zealand & Wellington & 1,401 & 4,789 & 12.0 & 399 & 493 \\
\hline Norway & Oslo & 971 & 20,263 & 20.0 & 1,013 & 342 \\
\hline Poland & Warsaw & 1,024 & 74,250 & 12.0 & 6,188 & 365 \\
\hline Portugal & Lisbon & 1,686 & 13,569 & 12.0 & 1,131 & 593 \\
\hline Romania & Bucharest & 1,324 & 3,857 & 12.0 & 321 & 466 \\
\hline Russia & Moscow & 996 & 656 & 15.0 & 44 & 350 \\
\hline Slovakia & Bratislava & 1,214 & 4,506 & 12.0 & 376 & 427 \\
\hline Slovenia & Ljubjana & 1,115 & 28,020 & 12.0 & 2,335 & 362 \\
\hline Spain & Madrid & 1,644 & 255,627 & 10.0 & 25,563 & 619 \\
\hline Sweden & Gothenburg & 934 & 243,798 & 10.0 & 24,380 & 389 \\
\hline Switzerland & Zürich & 1,094 & 288,358 & 11.0 & 26,214 & 385 \\
\hline Thailand & Bangkok & 1,765 & 4,098 & 12.0 & 342 & 621 \\
\hline United Kingdom & London & 943 & 22,316 & 12.0 & 1,860 & 332 \\
\hline Uruguay & Montevideo & 1,534 & 377 & 12.0 & 31 & 540 \\
\hline Zimbabwe & Harare & 2,017 & 689 & 12.0 & 57 & 710 \\
\hline \multirow{3}{*}{ All other countries } & & 1,105 & 890,636 & 12.0 & 74,220 & 389 \\
\hline & TOTAL & & $17,904,425$ & & $1,486,008$ & \\
\hline & AVERAGE & 1,305 & & 12.0 & & 389 \\
\hline
\end{tabular}

Combi system: system for the supply of domestic hot water and space heating

Table 9: Solar combi system reference for single and multifamily houses and the total collector area in operation in 2013 
Figure 48 shows the hydraulic scheme of domestic hot water reference system for multifamily houses as used for the simulations of the solar energy yields.

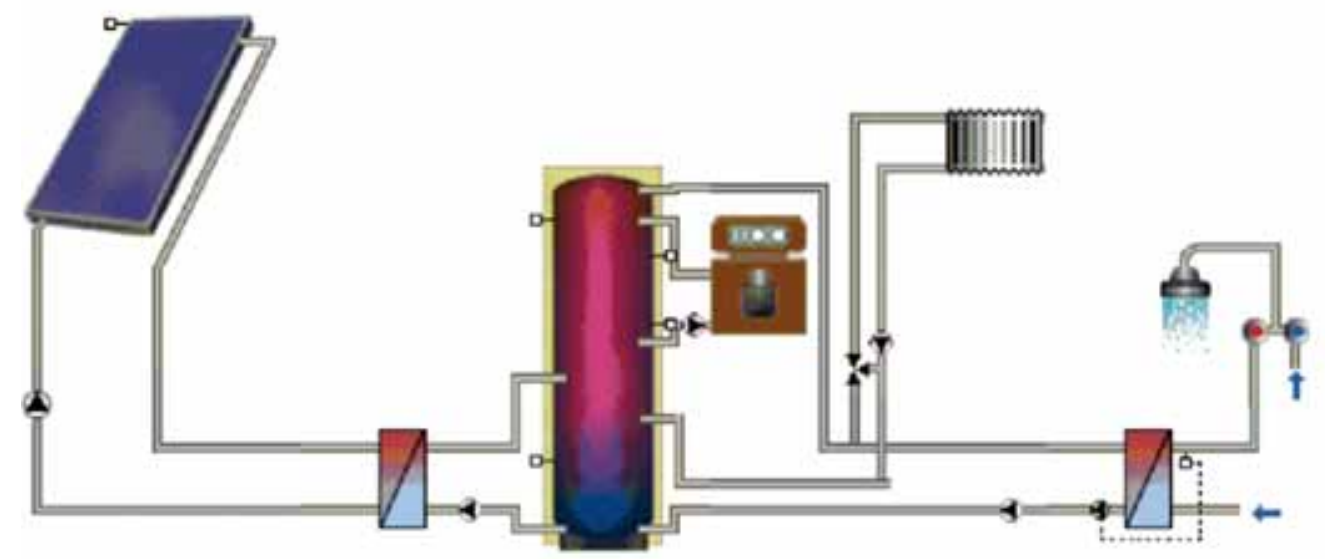

Figure 48: Hydraulic scheme of the solar-combi reference system for single and multifamily houses

\subsection{Reference collectors}

\subsubsection{Data of the reference unglazed water collector for swimming pool heating}

$$
\begin{aligned}
\eta & =0.85 \\
a_{1} & =20\left[\mathrm{~W} / \mathrm{m}^{2} \mathrm{~K}\right] \\
\mathrm{a}_{2} & =0.1\left[\mathrm{~W} / \mathrm{m}^{2} \mathrm{~K}^{2}\right]
\end{aligned}
$$

\subsubsection{Data of the reference collector for all other applications except for China}

$$
\begin{aligned}
\eta & =0.8 \\
a_{1} & =3.69\left[\mathrm{~W} / \mathrm{m}^{2} \mathrm{~K}\right] \\
\mathrm{a}_{2} & =0.007\left[\mathrm{~W} / \mathrm{m}^{2} \mathrm{~K}^{2}\right]
\end{aligned}
$$

\subsubsection{Data of the Chinese reference vacuum tube collector}

$$
\begin{aligned}
\eta & =0.74 \\
a_{1} & =2.5\left[\mathrm{~W} / \mathrm{m}^{2} \mathrm{~K}\right] \\
\mathrm{a}_{2} & =0.013\left[\mathrm{~W} / \mathrm{m}^{2} \mathrm{~K}^{2}\right]
\end{aligned}
$$




\subsection{Reference climates}

\begin{tabular}{|c|c|c|c|c|c|}
\hline \multirow[t]{2}{*}{ No. } & \multirow[t]{2}{*}{ Country } & \multirow[t]{2}{*}{ Reference climate } & Horizontal irradiation & Inclined irradiation & $\begin{array}{l}\text { Avg. Outside air } \\
\text { temp. }\end{array}$ \\
\hline & & & {$\left[\mathrm{kWh} / \mathrm{m}^{2} \cdot \mathrm{a}\right]$} & {$\left[\mathrm{kWh} / \mathrm{m}^{2} \cdot \mathrm{a}\right]$} & {$\left[{ }^{\circ} \mathrm{C}\right]$} \\
\hline 1 & Albania & Tirana & 1,604 & 1,835 & 13.5 \\
\hline 2 & Australia & Sydney & 1,674 & 1,841 & 18.1 \\
\hline 3 & Austria & Graz & 1,126 & 1,280 & 9.2 \\
\hline 4 & Barbados & Grantley Adams & 2,016 & 2,048 & 27.4 \\
\hline 5 & Belgium & Brussels & 971 & 1,095 & 10.0 \\
\hline 6 & Brazil & Brasília & 1,793 & 1,838 & 22.0 \\
\hline 7 & Bulgaria & Sofia & 1,188 & 1,304 & 10.1 \\
\hline 8 & Canada & Montreal & 1,351 & 1,568 & 6.9 \\
\hline 9 & Chile & Santiago de Chile & 1,753 & 1,850 & 14.5 \\
\hline 10 & China & Shanghai & 1,282 & 1,343 & 17.1 \\
\hline 11 & Croatia & Zagreb & 1,212 & 1,352 & 11.3 \\
\hline 12 & Cyprus & Nicosia & 1,886 & 2,098 & 19.9 \\
\hline 13 & Czech Republic & Praha & 998 & 1,111 & 7.9 \\
\hline 14 & Denmark & Copenhagen & 989 & 1,164 & 8.1 \\
\hline 15 & Estonia & Tallinn & 960 & 1,126 & 5.3 \\
\hline 16 & Finland & Helsinki & 948 & 1,134 & 4.6 \\
\hline 17 & France & Paris & 1,112 & 1,246 & 11.0 \\
\hline 18 & Germany & Würzburg & 1,091 & 1,225 & 9.5 \\
\hline 19 & Greece & Athens & 1,585 & 1,744 & 18.5 \\
\hline 20 & Hungary & Budapest & 1,199 & 1,346 & 11.0 \\
\hline 21 & India & New-Delhi & 1,961 & 2,275 & 24.7 \\
\hline 22 & Ireland & Dublin & 949 & 1,091 & 9.5 \\
\hline 23 & Israel & Jerusalem & 2,198 & 2,400 & 17.3 \\
\hline 24 & Italy & Bologna & 1,419 & 1,592 & 14.3 \\
\hline 25 & Japan & Tokyo & 1,175 & 1,287 & 16.7 \\
\hline 26 & Jordan & Amman & 2,145 & 2,341 & 17.9 \\
\hline 27 & Korea, South & Seoul & 1,161 & 1,280 & 12.7 \\
\hline 28 & Latvia & Riga & 991 & 1,187 & 6.3 \\
\hline 29 & Lebanon & Beirut & 1,935 & 2,132 & 19.9 \\
\hline 30 & Lithuania & Vilnius & 1,001 & 1,161 & 6.2 \\
\hline 31 & Luxembourg & Luxembourg & 1,037 & 1,158 & 8.4 \\
\hline 32 & Macedonia & Skopje & 1,381 & 1,521 & 12.5 \\
\hline 33 & Malta & Luqa & 1,902 & 2,115 & 18.7 \\
\hline 34 & Mauritius & Port Louis & 1,920 & 2,010 & 23.3 \\
\hline 35 & Mexico & Mexico City & 1,706 & 1,759 & 16.6 \\
\hline 36 & Morocco & Rabat & 2,000 & 2,250 & 17.2 \\
\hline 37 & Mozambique & Maputo & 1,910 & 2,100 & 22.8 \\
\hline 38 & Namibia & Windhoek & 2,363 & 2,499 & 21.0 \\
\hline 39 & Netherlands & Amsterdam & 999 & 1,131 & 10.0 \\
\hline 40 & New Zealand & Wellington & 1,401 & 1,542 & 13.6 \\
\hline 41 & Norway & Oslo & 971 & 1,208 & 5.8 \\
\hline 42 & Palestinian Territories & Jerusalem & 2,198 & 2,400 & 17.3 \\
\hline 43 & Poland & Warsaw & 1,024 & 1,156 & 8.1 \\
\hline 44 & Portugal & Lisbon & 1,686 & 1,875 & 17.4 \\
\hline 45 & Romania & Bucharest & 1,324 & 1,473 & 10.6 \\
\hline 46 & Russia & Moscow & 996 & 1,181 & 5.9 \\
\hline 47 & Slovakia & Bratislava & 1,214 & 1,374 & 10.3 \\
\hline 48 & Slovenia & Ljubjana & 1,115 & 1,231 & 9.8 \\
\hline 49 & South Africa & Johannesburg & 2,075 & 2,232 & 15.6 \\
\hline 50 & Spain & Madrid & 1,644 & 1,844 & 15.5 \\
\hline 51 & Sweden & Gothenburg & 934 & 1,105 & 7.2 \\
\hline 52 & Switzerland & Zürich & 1,094 & 1,218 & 9.6 \\
\hline 53 & Taiwan & Taipei & 1,372 & 1,398 & 20.8 \\
\hline 54 & Thailand & Bangkok & 1,765 & 1,898 & 29.1 \\
\hline 55 & Tunisia & Tunis & 1,808 & 2,038 & 19.3 \\
\hline 56 & Turkey & Antalya & 1,795 & 1,958 & 18.4 \\
\hline 57 & United Kingdom & London & 943 & 1,062 & 12.0 \\
\hline 58 & United States & LA, Indianapolis & 1,646 & 1,816 & 14.3 \\
\hline 59 & Uruguay & Montevideo & 1,534 & 1,647 & 15.9 \\
\hline 60 & Zimbabwe & Harare & 2,017 & 2,087 & 18.9 \\
\hline
\end{tabular}

Source: T-Sol expert version 4.5 and Meteonorm version 6.1.

Table 10: Reference climates for the 60 countries surveyed 


\subsection{Population data}

\begin{tabular}{|l|l|r|r|}
\hline No & Country & \multicolumn{1}{|c|}{$\mathbf{2 0 1 3}$} & Region code \\
\hline 1 & Albania & $3,011,405$ & 6 \\
\hline 2 & Australia & $22,262,501$ & 3 \\
\hline 3 & Austria & $8,221,646$ & 6 \\
\hline 4 & Barbados & 288,725 & 4 \\
\hline 5 & Belgium & $10,444,268$ & 6 \\
\hline 6 & Brazil & $201,009,622$ & 4 \\
\hline 7 & Bulgaria & $6,981,642$ & 6 \\
\hline 8 & Canada & $34,568,211$ & 8 \\
\hline 9 & Chile & $17,216,945$ & 4 \\
\hline 10 & China & $1,349,585,838$ & 5 \\
\hline 11 & Croatia & $4,475,611$ & 6 \\
\hline 12 & Cyprus & $1,155,403$ & 6 \\
\hline 13 & Czech Republic & $10,609,762$ & 6 \\
\hline 14 & Denmark & $5,556,452$ & 6 \\
\hline 15 & Estonia & $1,266,375$ & 6 \\
\hline 16 & Finland & $5,266,114$ & 6 \\
\hline 17 & France & $65,951,611$ & 6 \\
\hline 18 & Germany & $81,147,265$ & 6 \\
\hline 19 & Greece & $10,772,967$ & 6 \\
\hline 20 & Hungary & $9,939,470$ & 6 \\
\hline 21 & India & $1,220,800,359$ & 2 \\
\hline 22 & Ireland & $4,775,982$ & 6 \\
\hline 23 & Israel & $7,707,042$ & 7 \\
\hline 24 & Italy & $61,482,297$ & 6 \\
\hline 25 & Japan & $127,253,075$ & 2 \\
\hline 26 & Jordan & $6,482,081$ & 7 \\
\hline 27 & Korea, South & $48,955,203$ & 2 \\
\hline 28 & Latvia & $2,178,443$ & 6 \\
\hline 29 & Lebanon & $4,131,583$ & 7 \\
\hline 30 & Lithuania & $3,515,858$ & 6 \\
\hline 31 & Luxembourg & 514,862 & 6 \\
\hline 32 & Macedonia & $2,087,171$ & 6 \\
\hline 33 & Malta & 411,277 & 6 \\
\hline & & & \\
\hline
\end{tabular}

\begin{tabular}{|l|l|r|r|}
\hline No & Country & $\mathbf{2 0 1 3}$ & Region code \\
\hline 34 & Mauritius & $1,322,238$ & 1 \\
\hline 35 & Mexico & $118,818,228$ & 4 \\
\hline 36 & Morocco & $32,649,130$ & 7 \\
\hline 37 & Mozambique & $24,096,669$ & 1 \\
\hline 38 & Namibia & $2,182,852$ & 1 \\
\hline 39 & Netherlands & $16,805,037$ & 6 \\
\hline 40 & New Zealand & $4,365,113$ & 3 \\
\hline 41 & Norway & $5,085,582$ & 6 \\
\hline 42 & Palestinian Territories & $4,440,127$ & 7 \\
\hline 43 & Poland & $38,383,809$ & 6 \\
\hline 44 & Portugal & $10,799,270$ & 6 \\
\hline 45 & Romania & $21,790,479$ & 6 \\
\hline 46 & Russia & $142,500,482$ & 6 \\
\hline 47 & Slovakia & $5,488,339$ & 6 \\
\hline 48 & Slovenia & $1,992,690$ & 6 \\
\hline 49 & South Africa & $48,601,098$ & 1 \\
\hline 50 & Spain & $47,370,542$ & 6 \\
\hline 51 & Sweden & $9,647,386$ & 6 \\
\hline 52 & Switzerland & $7,996,026$ & 6 \\
\hline 53 & Taiwan & $23,299,716$ & 2 \\
\hline 54 & Thailand & $67,497,151$ & 2 \\
\hline 55 & Tunisia & $10,835,873$ & 7 \\
\hline 56 & Turkey & $80,694,485$ & 6 \\
\hline 57 & United Kingdom & $63,395,574$ & 6 \\
\hline 58 & United States & $316,438,601$ & 8 \\
\hline 59 & Uruguay & $3,324,460$ & 4 \\
\hline 60 & Zimbabwe & $13,182,908$ & 1 \\
\hline & Other countries & $2,635,464,300$ & 9 \\
\hline & & & \\
\hline$\Sigma$ Solar Thermal & $4,463,030,931$ & $63.0 \%$ \\
\hline World Statistics & $7,098,495,231$ & $100.0 \%$ \\
\hline$\Sigma$ Inhabitants world & & \\
\hline & & & \\
\hline
\end{tabular}

Data source: International Data Base of the U.S. Census Bureau http://www.census.gov/ipc/www/idb/country.php

Table 11: Inhabitants by the end of 2013 of the 60 surveyed countries in alphabetical order

\begin{tabular}{|c|c|c|c|}
\hline \multicolumn{2}{|c|}{ Region Code / Region } & $\sum$ Inhabitants & Share \\
\hline 1 & Sub-Sahara Africa & $89,385,765$ & $1.3 \%$ \\
\hline 2 & Asia excl. China & $1,487,805,504$ & $21.0 \%$ \\
\hline 3 & Australia / New Zealand & $26,627,614$ & $0.4 \%$ \\
\hline 4 & Latin America & $340,657,980$ & $4.8 \%$ \\
\hline 5 & China & $1,349,585,838$ & $19.0 \%$ \\
\hline 6 & Europe & $751,715,582$ & $10.6 \%$ \\
\hline 7 & MENA Region & $66,245,836$ & $0.9 \%$ \\
\hline 8 & United States / Canada & $351,006,812$ & $4.9 \%$ \\
\hline & Other countries & $2,635,464,300$ & $37.1 \%$ \\
\hline \multicolumn{2}{|c|}{ TOTAL } & $7,098,495,231$ & $100.0 \%$ \\
\hline
\end{tabular}

Data source: International Data Base of the U.S. Census Bureau http://www.census.gov/ipc/www/idb/country.php

Sub-Sahara Africa: Mauritius, Mozambique, Namibia, South Africa, Zimbabwe

Asia excluding China: India, Japan, Korea South, Taiwan, Thailand

Latin America: Barbados, Brazil, Chile, Mexico, Uruguay

Europe: EU 28, Albania, Macedonia, Norway, Russia, Switzerland, Turkey

MENA Region: Israel, Jordan, Lebanon, Morocco, Palestinian Territories, Tunisia

Table 12: Inhabitants per economic region

by the end of 2013 


\subsection{Market data of the previous years}

The data presented in Chapters 3 through 5 were originally collected in square meters. Through an agreement of international experts the collector areas of these solar thermal applications have been converted and are shown in installed capacity as well.

Making the installed capacity of solar thermal collectors comparable with that of other energy sources, solar thermal experts from seven countries agreed upon a methodology to convert installed collector area into solar thermal capacity.

The methodology was developed during a meeting with IEA SHC Programme officials and major solar thermal trade associations in Gleisdorf, Austria in September 2004. The represented associations from Austria, Canada, Germany, the Netherlands, Sweden and the United States as well as the European Solar Thermal Industry Federation (ESTIF) and the IEA SHC Programme agreed to use a factor of $0.7 \mathrm{~kW}$ th $/ \mathrm{m}^{2}$ to derive the nominal capacity from the area of installed collectors.

In order to ensure consistency of the calculations within this report the following tables provide data from the previous years. If necessary the numbers have been revised in 2013 compared to the data originally published in earlier editions of this report due to changes in methodology or the origin of the data for each country.

In the following Table 13, Table 14 and Table 15 these countries are highlighted accordingly and in Chapter 8.6 (References) the respective data source is cited. 


\begin{tabular}{|c|c|c|c|c|c|c|}
\hline \multirow{2}{*}{ Country } & \multicolumn{3}{|c|}{ Water Collectors [ $\left.\mathrm{m}^{2}\right]$} & \multicolumn{2}{|c|}{ Air Collectors $\left[\mathrm{m}^{2}\right]$} & \multirow{2}{*}{ TOTAL $\left[\mathrm{m}^{2}\right]$} \\
\hline & unglazed & FPC & ETC & unglazed & glazed & \\
\hline Albania & & 12,890 & 98 & & & 12,988 \\
\hline Australia & 600,000 & 343,980 & 22,230 & 36,000 & 900 & $1,003,110$ \\
\hline Austria & 5,700 & 221,500 & 8,690 & & 350 & 236,240 \\
\hline \multicolumn{7}{|l|}{ Barbados** } \\
\hline Belgium & & 35,500 & 10,000 & & & 45,500 \\
\hline Brazil & 512,099 & 517,517 & & & & $1,029,616$ \\
\hline Bulgaria & & 10,000 & 800 & & & 10,800 \\
\hline Canada & 74,490 & 7,880 & 9,500 & 28,377 & 7,165 & 127,412 \\
\hline Chile & & 19,037 & & & & 19,037 \\
\hline China & & $2,880,000$ & $54,720,000$ & & & $57,600,000$ \\
\hline Croatia* & & 14,587 & & & & 14,587 \\
\hline Cyprus & 142 & 26,794 & 1,643 & & & 28,579 \\
\hline Czech Republic & 65,000 & 49,150 & 16,650 & & & 130,800 \\
\hline Denmark & & 61,897 & 504 & & & 62,401 \\
\hline Estonia & & 900 & 900 & & & 1,800 \\
\hline Finland & & 3,000 & 1,000 & & & 4,000 \\
\hline France (mainland) & & 242,200 & 8,800 & 553 & 117 & 251,670 \\
\hline Germany & & $1,152,000$ & 118,000 & 428 & 0 & $1,270,428$ \\
\hline Greece & & 230,000 & & & & 230,000 \\
\hline Hungary & 1,500 & 14,000 & 6,000 & 300 & 250 & 22,050 \\
\hline India* & & 381,600 & 572,400 & & 1,200 & 955,200 \\
\hline Ireland & & 12,538 & 8,232 & & & 20,770 \\
\hline Israel & 2,500 & 370,984 & & & & 373,484 \\
\hline Italy & & 339,300 & 50,700 & & & 390,000 \\
\hline Japan & & 155,264 & 1,802 & & 10,773 & 167,839 \\
\hline Jordan & & 54,531 & 13,705 & & & 68,236 \\
\hline Korea, South & & 54,733 & & & & 54,733 \\
\hline Latvia & & 1,000 & 800 & & & 1,800 \\
\hline Lebanon & & 40,000 & 20,000 & & & 60,000 \\
\hline Lithuania & & 600 & 1,200 & & & 1,800 \\
\hline Luxembourg & & 3,500 & 1,000 & & & 4,500 \\
\hline Macedonia* & & 5,120 & 453 & & & 5,573 \\
\hline Malta & & 2,335 & 480 & & & 2,815 \\
\hline \multicolumn{7}{|l|}{ Mauritius \# } \\
\hline Mexico & 90,000 & 95,000 & 85,000 & 300 & & 270,300 \\
\hline Morocco* & & 36,000 & & & & 36,000 \\
\hline Mozambique & & & 130 & & & 130 \\
\hline \multicolumn{7}{|l|}{ Namibia** } \\
\hline Netherlands & 27,396 & 31,445 & 5,000 & & & 63,841 \\
\hline \multicolumn{7}{|l|}{ New Zealand** } \\
\hline Norway & 160 & 2,863 & 946 & & & 3,969 \\
\hline \multicolumn{7}{|l|}{ Palestinian Territ. \# } \\
\hline Poland & & 187,400 & 66,300 & & & 253,700 \\
\hline Portugal & 235 & 126,227 & 736 & 204 & & 127,402 \\
\hline Romania & & 8,500 & 7,000 & & & 15,500 \\
\hline \multicolumn{7}{|l|}{ Russia } \\
\hline Slovakia & & 19,320 & 3,680 & & & 23,000 \\
\hline Slovenia & & 9,000 & 3,000 & & & 12,000 \\
\hline South Africa & 48,200 & 42,811 & 39,300 & & & 130,311 \\
\hline Spain & 8,600 & 249,700 & 17,250 & 1,500 & & 277,050 \\
\hline Sweden & 22,601 & 15,654 & 5,153 & & & 43,408 \\
\hline Switzerland & 9,040 & 129,142 & 8,721 & 9,000 & & 155,903 \\
\hline Taiwan & & 100,386 & 11,061 & & & 111,447 \\
\hline Thailand & & 18,900 & & & & 18,900 \\
\hline Tunisia & & 64,300 & 8,000 & & & 72,300 \\
\hline Turkey & & $1,301,075$ & 504,600 & 1,570 & & $1,807,245$ \\
\hline United Kingdom & & 72,953 & 18,826 & 5,597 & & 97,376 \\
\hline United States & 747,900 & 220,000 & 11,400 & 15,500 & 6,000 & $1,000,800$ \\
\hline \multicolumn{7}{|l|}{ Uruguay** } \\
\hline Zimbabwe & & 230 & 320 & & & 550 \\
\hline All other countries \# & 116,609 & 526,065 & $2,968,000$ & 5,228 & 1,408 & $3,617,310$ \\
\hline TOTAL & $2,332,172$ & $10,521,308$ & $59,360,010$ & 104,557 & 28,163 & $72,346,209$ \\
\hline
\end{tabular}

* revised due to new / adapted database in 2015

** no data for new installations in the respective year available

Table 13: Newly installed collector area in 2011 (revised 2015) [m²] 


\begin{tabular}{|c|c|c|c|c|c|c|}
\hline \multirow{2}{*}{ Country } & \multicolumn{3}{|c|}{ Water Collectors $\left[\mathrm{m}^{2}\right]$} & \multicolumn{2}{|c|}{ Air Collectors $\left[\mathrm{m}^{2}\right]$} & \multirow{2}{*}{ TOTAL $\left[\mathrm{m}^{2}\right]$} \\
\hline & unglazed & glazed & evacuated tube & unglazed & glazed & \\
\hline Albania & & 21,060 & 140 & & & 21,200 \\
\hline Australia & 650,000 & 239,400 & 30,450 & 35,000 & 1,000 & 955,850 \\
\hline Austria & 2,410 & 200,800 & 5,590 & & 830 & 209,630 \\
\hline \multicolumn{7}{|l|}{ Barbados** } \\
\hline Belgium & & 50,500 & 11,500 & & & 62,000 \\
\hline Brazil & 525,508 & 625,855 & & & & $1,151,363$ \\
\hline Bulgaria & & 7,400 & 600 & & & 8,000 \\
\hline Canada & 71,510 & 6,513 & 7,812 & 15,824 & 12,359 & 114,018 \\
\hline Chile* & & 20,000 & & & & 20,000 \\
\hline China* & & $4,850,000$ & $57,150,000$ & & & $62,000,000$ \\
\hline Croatia* & & 18,474 & & & & 18,474 \\
\hline Cyprus & 24 & 20,646 & 1,439 & & & 22,109 \\
\hline Czech Republic & 50,000 & 37,000 & 13,000 & & & 100,000 \\
\hline Denmark & & 112,500 & 500 & & & 113,000 \\
\hline Estonia & & 900 & 900 & & & 1,800 \\
\hline Finland & & 3,000 & 1,000 & & & 4,000 \\
\hline $\begin{array}{l}\text { France } \quad \text { (main- } \\
\text { land) }\end{array}$ & & 240,750 & 8,750 & 4,500 & 1,000 & 255,000 \\
\hline Germany & & $1,036,000$ & 114,000 & & & $1,150,000$ \\
\hline Greece & & 241,500 & 1,500 & & & 243,000 \\
\hline Hungary & 1,500 & 35,000 & 15,000 & 300 & 250 & 52,050 \\
\hline India* & & 429,000 & $1,001,000$ & & 2,500 & $1,432,500$ \\
\hline Ireland & & 18,516 & 8,148 & & & 26,664 \\
\hline Israel & 1,200 & 310,500 & & & & 311,700 \\
\hline Italy & & 283,800 & 46,200 & & & 330,000 \\
\hline Japan & & 158,741 & 3,208 & & 7,950 & 169,899 \\
\hline Jordan & & 54,531 & 13,705 & & & 68,236 \\
\hline Korea, South & & 63,774 & & & & 63,774 \\
\hline Latvia & & 150 & 150 & & & 300 \\
\hline Lebanon* & & 34,000 & 10,000 & & & 44,000 \\
\hline Lithuania & & 600 & 1,200 & & & 1,800 \\
\hline Luxembourg & & 3,250 & 900 & & & 4,150 \\
\hline Macedonia* & & 5,120 & 453 & & & 5,573 \\
\hline Malta & & 1,499 & 510 & & & 2,009 \\
\hline Mauritius \# & & 43,470 & & & & 43,470 \\
\hline Mexico & 109,500 & 95,250 & 95,250 & & & 300,000 \\
\hline Morocco* & & 36,000 & & & & 36,000 \\
\hline Mozambique & & & 143 & & & 143 \\
\hline \multicolumn{7}{|l|}{ Namibia** } \\
\hline Netherlands & 27,396 & 27,972 & 8,000 & & & 63,368 \\
\hline \multicolumn{7}{|l|}{ New Zealand** } \\
\hline Norway & & 15,236 & 795 & & 1,983 & 18,014 \\
\hline Palestin. Territ. \# & & 115,000 & 7,000 & & & 122,000 \\
\hline Poland & & 216,000 & 86,000 & & & 302,000 \\
\hline Portugal & 182 & 83,624 & 7,090 & & & 90,896 \\
\hline Romania & & 8,500 & 7,000 & & & 15,500 \\
\hline Russia & & 6,097 & 287 & & & 6,384 \\
\hline Slovakia & & 6,500 & 1,000 & & & 7,500 \\
\hline Slovenia & & 13,500 & 3,000 & & & 16,500 \\
\hline South Africa & 49,068 & 22,176 & 50,344 & & & 121,588 \\
\hline Spain & 3,591 & 211,060 & 12,623 & & & 227,274 \\
\hline Sweden & 910 & 8,251 & 3,006 & & & 12,167 \\
\hline Switzerland & 11,815 & 125,609 & 17,287 & & & 154,711 \\
\hline Taiwan & 5 & 105,698 & 11,848 & & & 117,551 \\
\hline Thailand & & 22,660 & & & & 22,660 \\
\hline Tunisia & & 74,238 & 2,180 & & & 76,418 \\
\hline Turkey & & $1,146,298$ & 478,000 & & & $1,624,298$ \\
\hline United Kingdom & & 47,893 & 11,382 & 5,000 & & 64,275 \\
\hline United States & 757,400 & 229,700 & 12,000 & 15,000 & 14,000 & $1,028,100$ \\
\hline \multicolumn{7}{|l|}{ Uruguay** } \\
\hline Zimbabwe & & 802 & 570 & & & 1,372 \\
\hline $\begin{array}{l}\text { Other countries } \\
(5 \%) \#\end{array}$ & 119,054 & 620,648 & $3,119,077$ & 3,980 & 2,204 & $3,864,963$ \\
\hline TOTAL & $2,381,073$ & $12,412,961$ & $62,381,537$ & 79,604 & 44,076 & $77,299,251$ \\
\hline
\end{tabular}

* revised due to new / adapted database in 2015

** no data for new installations in the respective year available

\# $\quad$ added in 2015

Table 14: Newly installed collector area in 2012 (revised 2015) [m²] 


\begin{tabular}{|c|c|c|c|c|c|c|}
\hline \multirow{2}{*}{ Country } & \multicolumn{3}{|c|}{ Water Collectors $\left[\mathrm{m}^{2}\right]$} & \multicolumn{2}{|c|}{ Air Collectors $\left[\mathrm{m}^{2}\right]$} & \multirow{2}{*}{ TOTAL $\left[\mathrm{m}^{2}\right]$} \\
\hline & unglazed & glazed & evacuated tube & unglazed & glazed & \\
\hline Albania & & 111,135 & 786 & & & 111,921 \\
\hline Australia & $4,350,000$ & $2,908,000$ & 68,000 & 280,000 & 7,200 & $7,613,200$ \\
\hline Austria & 558,601 & $4,289,605$ & 79,542 & & 1,908 & $4,929,656$ \\
\hline Barbados** & & 131,690 & & & & 131,690 \\
\hline Belgium & 45,000 & 329,469 & 55,064 & & & 429,533 \\
\hline Brazil & $2,314,735$ & $5,947,321$ & & & & $8,262,056$ \\
\hline Bulgaria & & 120,050 & 2,050 & & & 122,100 \\
\hline Canada & 778,102 & 61,475 & 35,695 & 349,750 & 24,140 & $1,249,162$ \\
\hline Chile & & 80,009 & & & & 80,009 \\
\hline China* & & $22,707,614$ & $300,392,386$ & & & $323,100,000$ \\
\hline Croatia & & 120,000 & & & & 120,000 \\
\hline Cyprus* & 2,147 & 684,681 & 23,095 & & & 709,923 \\
\hline Czech Republic & 468,000 & 335,813 & 87,925 & & & 891,738 \\
\hline Denmark & 20,515 & 634,310 & 8,584 & 3,264 & 18,000 & 684,673 \\
\hline Estonia & & 3,930 & 2,590 & & & 6,520 \\
\hline Finland & 11,779 & 30,251 & 6,472 & & & 48,502 \\
\hline France (mainland)* & 105,699 & $2,032,271$ & 42,129 & 5,053 & 1,117 & $2,186,269$ \\
\hline Germany* & 585,600 & $14,257,000$ & $1,802,000$ & & 30,720 & $16,675,320$ \\
\hline Greece & & $4,104,200$ & 17,800 & & & $4,122,000$ \\
\hline Hungary & 13,500 & 168,700 & 51,100 & 1,800 & 1,450 & 236,550 \\
\hline India* & & $2,923,010$ & $2,208,190$ & & 4,200 & $5,135,400$ \\
\hline Ireland & & 184,524 & 87,444 & & & 271,968 \\
\hline Israel* & 31,817 & $4,144,576$ & 422 & 550 & & $4,177,365$ \\
\hline Italy & 43,766 & $2,926,580$ & 476,420 & & & $3,446,766$ \\
\hline Japan & & $4,378,220$ & 83,340 & & 502,949 & $4,964,509$ \\
\hline Jordan & 5,940 & 873,420 & 244,674 & & & $1,124,034$ \\
\hline Korea, South & & $1,684,824$ & & & & $1,684,824$ \\
\hline Latvia & & 2,850 & 1,190 & & & 4,040 \\
\hline Lebanon & & 234,000 & 292,000 & & & 526,000 \\
\hline Lithuania & & 3,300 & 2,700 & & & 6,000 \\
\hline Luxembourg & & 35,050 & 4,750 & & & 39,800 \\
\hline Macedonia & & 35,260 & 1,630 & & & 36,890 \\
\hline Malta & & 37,650 & 9,413 & & & 47,063 \\
\hline Mauritius \# & & 106,233 & & & & 106,233 \\
\hline Mexico & 756,703 & 856,757 & 613,617 & 352 & 8,373 & $2,235,802$ \\
\hline Morocco & & 379,000 & & & & 379,000 \\
\hline Mozambique & & & 273 & & & 273 \\
\hline Namibia** & & 20,699 & 1,307 & & & 22,006 \\
\hline Netherlands & 418,783 & 428,859 & 17,000 & & & 864,642 \\
\hline New Zealand** & 7,025 & 142,975 & 9,644 & & & 159,645 \\
\hline Norway & 2,007 & 31,445 & 2,674 & & 2,961 & 39,088 \\
\hline Palestinian Territ. \# & & $1,505,000$ & 0 & & & $1,505,000$ \\
\hline Poland & & 916,500 & 295,000 & & & $1,211,500$ \\
\hline Portugal & 2,128 & 834,777 & 22,090 & & & 858,995 \\
\hline Romania & & 80,700 & 30,000 & & & 110,700 \\
\hline Russia & & 17,601 & 1,297 & & & 18,898 \\
\hline Slovakia & & 125,920 & 21,080 & & & 147,000 \\
\hline Slovenia & & 167,550 & 19,250 & & & 186,800 \\
\hline South Africa & 866,871 & 381,044 & 115,597 & & & $1,363,512$ \\
\hline Spain & 134,191 & $2,661,260$ & 167,373 & & & $2,962,824$ \\
\hline Sweden & 130,000 & 260,000 & 60,000 & & & 450,000 \\
\hline Switzerland & 211,540 & 980,970 & 72,980 & 876,000 & & $2,141,490$ \\
\hline Taiwan & 2,254 & $1,324,383$ & 107,546 & & & $1,434,183$ \\
\hline Thailand & & 120,360 & & & & 120,360 \\
\hline Tunisia & & 593,038 & 46,180 & & & 639,218 \\
\hline Turkey & & $12,763,258$ & $1,811,970$ & 1,570 & & $14,576,798$ \\
\hline United Kingdom & & 537,990 & 171,683 & 19,000 & & 728,673 \\
\hline United States & $20,444,848$ & $2,647,521$ & 117,232 & 95,239 & 20,000 & $23,324,841$ \\
\hline Uruguay** & & 12,571 & & & & 12,571 \\
\hline Zimbabwe & & 18,761 & 807 & & & 19,568 \\
\hline All other countries \# & $1,700,608$ & $5,496,630$ & $16,304,842$ & 85,925 & 32,790 & $23,620,795$ \\
\hline TOTAL 2010 & $34,012,159$ & $109,932,591$ & $326,096,834$ & $1,718,504$ & 655,809 & $472,415,896$ \\
\hline
\end{tabular}

* revised due to new / adapted database in 2015

** no data for new installations in the respective year available

\# $\quad$ added in 2015

Table 15: Total collector area in operation by the end of 2012 (revised 2015) [m²] 


\subsection{References to reports and persons that have supplied the data}

The production of the report, Solar Heat Worldwide 2013 - Edition 2015 edition was kindly supported by national representatives of the recorded countries or other official sources of information as cited below.

\begin{tabular}{|c|c|c|}
\hline COUNTRY & CONTACT & $\begin{array}{l}\text { SOURCE } \\
\text { REMARKS }\end{array}$ \\
\hline Albania & $\begin{array}{l}\text { Dr. Eng. Edmond M. HIDO } \\
\text { EEC - Albania-EU Energy Efficiency Centre (EEC) }\end{array}$ & EEC - Albania-EU Energy Efficiency Centre \\
\hline Australia & $\begin{array}{l}\text { Dr. David Ferrari } \\
\text { Sustainability Victoria }\end{array}$ & $\begin{array}{l}\text { Sustainability Victoria } \\
\text { Out of operation systems calculated by Sustainability Victoria }\end{array}$ \\
\hline Austria & $\begin{array}{l}\text { Werner Weiss } \\
\text { AEE - Institute for Sustainable Technologies }\end{array}$ & $\begin{array}{l}\text { Biermayr et al, 2014: } \\
\text { Innovative energy technologies in Austria - Market } \\
\text { Development } 2013 \\
\text { Out of operation systems calculated by AEE INTEC }\end{array}$ \\
\hline Barbados & & No data available since 2009, Cumulated area by end of 2009 \\
\hline Belgium & $\begin{array}{l}\text { ESTIF - European Solar Thermal } \\
\text { Industry Federation }\end{array}$ & Glazed water collectors: ESTIF, 2014 \\
\hline & AEE INTEC & Unglazed water collectors: AEE INTEC recordings \\
\hline Brazil & $\begin{array}{l}\text { Marcelo Mesquita } \\
\text { Depto. Nac. de Aquecimento Solar da ABRAVA }\end{array}$ & $\begin{array}{l}\text { DASOL ABRAVA } \\
\text { Out of operation systems calculated based on DASOL ABRAVA } \\
\text { long time recordings }\end{array}$ \\
\hline Bulgaria & $\begin{array}{l}\text { ESTIF - European Solar Thermal } \\
\text { Industry Federation }\end{array}$ & Glazed water collectors: ESTIF, 2014 \\
\hline & AEE INTEC & Unglazed water collectors: AEE INTEC recordings \\
\hline Canada & $\begin{array}{l}\text { Reda Djebbar, Ph.D., P.Eng. } \\
\text { Natural Resources Canada }\end{array}$ & $\begin{array}{l}\text { Clear Sky Advisors, April } 2015 \text { Report - "Survey of } \\
\text { Active Solar Thermal Collectors, Industry and Mar- } \\
\text { kets in Canada (2013/2014)" } \\
\text { Out of operation systems considered by NRC }\end{array}$ \\
\hline Chile & AEE INTEC & $\begin{array}{l}\text { AEE INTEC, } 2015 \text { (estimation) } \\
\text { Cumulated installations by end of } 2013 \text { based on estimation for } \\
\text { new installations in } 2012 \text { and } 2013\end{array}$ \\
\hline China & $\begin{array}{l}\text { Hu Runqing } \\
\text { Center for Renewable Energy Development - } \\
\text { Energy Research Institute (NDRC) }\end{array}$ & $\begin{array}{l}\text { CSTIF - Chinese Solar Thermal Industry Federation } \\
\text { Out of operation systems calculated by CSTIF - new methodol- } \\
\text { ogy considered }\end{array}$ \\
\hline Croatia & $\begin{array}{l}\text { ESTIF - European Solar Thermal } \\
\text { Industry Federation }\end{array}$ & Glazed water collectors: ESTIF, 2014 \\
\hline Cyprus & $\begin{array}{l}\text { Soteris Kalogirou, PhD, DSc } \\
\text { Cyprus University of Technology }\end{array}$ & $\begin{array}{l}\text { Cyprus Institue of Energy provided } \\
\text { New installations: Cyprus Institute of Energy }\end{array}$ \\
\hline & $\begin{array}{l}\text { ESTIF - European Solar Thermal } \\
\text { Industry Federation }\end{array}$ & $\begin{array}{l}\text { Cumulated installations: ESTIF } 2014 \text { / share FPC-ETC + un- } \\
\text { glazed: CYPRUS INTSTITUTE OF ENERGY }\end{array}$ \\
\hline Czech Republic & $\begin{array}{l}\text { Ales Bufka } \\
\text { Ministry of Industry and Trade }\end{array}$ & Ministry of Industry and Trade \\
\hline Denmark & $\begin{array}{l}\text { ESTIF - European Solar Thermal } \\
\text { Industry Federation }\end{array}$ & Glazed water collectors: ESTIF, 2014 \\
\hline & AEE INTEC & Unglazed water collectors: AEE INTEC recordings \\
\hline
\end{tabular}




\begin{tabular}{|c|c|c|}
\hline Estonia & $\begin{array}{l}\text { ESTIF - European Solar Thermal } \\
\text { Industry Federation }\end{array}$ & Glazed water collectors: ESTIF, 2014 (estimation) \\
\hline \multirow[t]{2}{*}{ Finland } & $\begin{array}{l}\text { ESTIF - European Solar Thermal } \\
\text { Industry Federation }\end{array}$ & Glazed water collectors: ESTIF, 2014 (estimation) \\
\hline & AEE INTEC & Unglazed water collectors: AEE INTEC recordings \\
\hline \multirow[t]{2}{*}{ France (mainland) } & $\begin{array}{l}\text { Céline Coulaud } \\
\text { ADEME - Centre de Sophia Antipolis }\end{array}$ & $\begin{array}{l}\text { Glazed water collectors: ADEME; Enerplan } \\
\text { New installations: Uniclima/Enerplan/ADEME - provided by } \\
\text { Celine Coulaud }\end{array}$ \\
\hline & $\begin{array}{l}\text { John Hollick } \\
\text { SAHWIA - Solar Air Heating World Industry } \\
\text { Association }\end{array}$ & $\begin{array}{l}\text { Air collectors: SAHWIA } \\
\text { Air collectors data provided by John Hollick }\end{array}$ \\
\hline
\end{tabular}

\section{ESTIF - European Solar Thermal Industry Federation}

Germany

\section{Jan Knaack}

BSW - Bundesverband Solarwirtschaft e.V.

\section{John Hollick}

SAHWIA - Solar Air Heating World Industry Association

\section{Greece}

Vassiliki Drosou, M.Sc. PhD

CRES - Centre for Renewable Energy Sources

\section{AEE INTEC}

$\begin{array}{ll}\text { Hungary } & \text { Pál Varga } \\ \text { MÉGNAP- Hungarian Solar Thermal Industry } \\ \text { Federation }\end{array}$

India Jaideep N. Malaviya

Malaviya Solar Energy Consultancy

Ireland Mary Holland

Sustainable Energy Authority of Ireland

$\begin{array}{ll}\text { Israel } & \text { Dr. Asher Vaturi } \\ \text { ICTAF - Israel Bureau of Statistics }\end{array}$

Unglazed water collectors: AEE INTEC recordings Cumulated installations: ESTIF 2014 / share FPC-ETC: AEE INTEC / unglazed water collectors: AEE INTEC

Glazed water collectors: BSW-Solar

New installations: water collectors: BSW-Solar; ESTIF 2014

Unglazed water collectors: AEE INTEC recordings Air collectors: SAHWIA

Cumulated installations: water collectors: calculated by AEE INTEC based on BSW-Solar long-time recordings, 20 years life-time considered; air collectors: AEE INTEC recordings

Vassiliki Drosou (CRES), Costas Travasoras (EBHE) New installations: ETC/FPC by ESTIF; Vassiliki DROSOU (CRES), Costas TRAVASAROS (EBHE)

Cumulated installations: cumulated area: ESTIF 2014 / share FPC-ETC: AEE INTEC

MÉGNAP- Hungarian Solar Thermal Industry Federation

New and cumulated installations: Hungarian Solar Thermal Industry Federation (MÉGNAP).; provided by Pál Varga (personal estimation )

Malaviya Solar Energy Consultancy (based on market survey)

New and cumulated installations based on survey from Malaviya Solar Energy Consultancy; out of operation systems considered!

Energy policy statistical support unit of Sustainable Energy Authority of Ireland

Grant scheme data; BER database: Source: Energy policy statistical support unit of Sustainable Energy Authority of Ireland; provided by Mary Holland

Israel Bureau of Statistics, Israel Ministry of water and energy \& The Max Stern Yezreel Valley College (Dr. Asher Vaturi)

Out of operation systems (replacements) considered by ICTAF

Italy

ESTIF - European Solar Thermal Industry Federation

Glazed water collectors: ESTIF, 2014

AEE INTEC

Japan

Yamashita Noriaki

ISEP - Institute for Sustainable Energy Policies
Unglazed water collectors: AEE INTEC recordings ISEP;

Solar System Development Association (SSDA)

Out of operation systems calculated by ISEP 


Jordan AEE INTEC

Korea, South Eunhee Jeong

Korea Energy Management Corporation (KEMCO)

\begin{tabular}{ll}
\hline Latvia & $\begin{array}{l}\text { ESTIF - European Solar Thermal } \\
\text { Industry Federation }\end{array}$ \\
\hline Lebanon & $\begin{array}{l}\text { Tony Matar } \\
\text { The Lebanese Association for Energy Saving \& } \\
\text { for Environment (ALMEE) }\end{array}$ \\
\hline Lithuania & $\begin{array}{l}\text { ESTIF - European Solar Thermal } \\
\text { Industry Federation }\end{array}$ \\
\hline Luxembourg & ESTIF - European Solar Thermal \\
& Industry Federation \\
\hline Macedonia & $\begin{array}{l}\text { Prof. Dr. Ilja Nasov } \\
\text { National University St.Kiril and Metodij, } \\
\text { Faculty for Natural Science, Institute of Physics, } \\
\text { Solar Energy Department }\end{array}$
\end{tabular}

\begin{tabular}{ll}
\hline Malta & Godwin Sant \\
Malta Resources Authority
\end{tabular}

Mauritius Devika Balgobin

Statistician / Environment Statistics Unit Ministry of Environment and Sustainable Development

Mexico

\section{Information provided by Bärbel Epp}

Solrico - Solar market research http://www.solrico.com/
AEE INTEC, 2015 (estimation)

New installations: projected by AEE INTEC ( $0 \%$ growth rate 2012/2013)

Cumulated installations: calculated by AEE INTEC based on estimation for new installations in 2013

2013 New \& Renewable Energy Statistics by the Korea New \& Renewable Energy Center, 2014

Glazed water collectors: ESTIF, 2014 (estimation)

The Lebanese Association for Energy Saving \& for Environment (ALMEE)

Out of operation systems considered by ALMEE

Glazed water collectors: ESTIF, 2014 (estimation)

Glazed water collectors: ESTIF, 2014 (estimation)

New installations: estimation of Ilya Nasov and other solar experts

New installations: estimation of Ilya Nasov and other solar experts;

cumulated installations: calculated by AEE INTEC based on new installation figures

Sustainable Energy and Water Conservation Unit (SEWCU) based on data provided by the Malta Resources Authority

Statistics Mauritius

New and cumulated installations 2013 - provided by Devika Balgobin - Statistics Mauritius

Glazed and unglazed water collectors: FAMERAC Renewable Energy Industry Association

Air collectors: SAHWIA - Solar Air Heating World Industry Association

New installations: Water collectors: FAMERAC; air collector data: SAHWIA

Cumulated installations: calculated by AEE INTEC based on data from ANES and solarthermalworld.org

$\begin{array}{ll}\text { Morocco } & \text { Ashraf Kraidy } \\ \text { RECREEE - Regional Center for Renewable } \\ \text { Energy and Energy Efficiency }\end{array}$

ADEREE - L'Agence Nationale pour le Développement des Energies New installations (water collectors): ADEREE; provided by Ashraf Kraidy (new installations 2012 and 2011 estimated by AEE INTEC)

Mozambique AEE INTEC

AEE INTEC, 2015 (estimation)

Cumulated installations by end of 2013 based on estimation for new installations in 2012 and 2013

Namibia

No data available since 2011. Cumulated area by end of 2012

Netherlands Reinoud Segers

Statistics Netherlands (CBS)

Statistics Netherlands (CBS)

Cumulated areas: Statistics Netherlands based on survey of sales. Market Shares: Expert estimates Netherlands Enterprise Agency and Holland Solar. 
Turkey

\section{A. Kutay Ulke}

EZINC Metal San. Tic. A.S.

John Hollick

SAHWIA - Solar Air Heating World Industry Association
Water collectors: Ezinc Metal San. Tic. A.S.

New installations: Ezinc Metal San. Tic. A.S

cumulated installations: calculated by AEE INTEC considering replacements

Air collectors: SAHWIA

\begin{tabular}{lll}
\hline United Kingdom & $\begin{array}{l}\text { ESTIF - European Solar Thermal } \\
\text { Industry Federation }\end{array}$ & Glazed water collectors: ESTIF, 2014 \\
\hline United States & $\begin{array}{l}\text { Les Nelson } \\
\text { IAPMO Solar Heating \& Cooling } \\
\text { Programs }\end{array}$ & $\begin{array}{l}\text { Water Collectors and air collectors: IAPMO Solar } \\
\text { Heating \& Cooling Programs; } \\
\text { Out of operation systems considered based on historical data } \\
(1975-2009) \text { from U.S. Department of Energy (DoE) - Energy } \\
\text { Information Administration (EIA) }\end{array}$ \\
& John Hollick & Air collectors: SAHWIA \\
\hline Uruguay & SAHW - Solar Air Heating World Industry Association \\
\hline Zimbabwe & Anton Schwarzlmüller & No data available since 2010. Cumulated area by end of 2011 \\
\hline
\end{tabular}




\subsubsection{Additional literature and web sources used}

\section{The following reports and statistics were used in this report:}

- Bundesamt für Energie (BFE): Markterhebung Sonnenenergie 2013 - Teilstatistik der Schweizerischen Statistik der erneuerbaren Energien; prepared by SWISSOLAR, Thomas Hostettler, Bern, Switzerland July 2014

- Bundesministerium für Verkehr, Innovation und Technologie (BMVIT): Innovative energy technologies in Austria Market Development 2013; prepared by Peter Biermayr et al., Vienna, Austria May 2014

- Bundesverband Solarwirtschaft e.V. (BSW-Solar): Statistische Zahlen der deutschen Solarwärmebranche (Solarthermie) 2014; accessed on April 2015

- ClearSky Advisors Inc.: Survey of Active Solar Thermal Collectors, Industry and Markets in Canada (2013/2014); Prepared by ClearSky Advisors Inc., Dr. Reda Djebbar, Natural Resources Canada, March 2015

- European Solar Thermal Industry Federation (ESTIF): Solar Thermal Markets in Europe, Trends and Market Statistics 2013; Belgium - Brussels; June 2014

\section{The following online sources were used in this report:}

- http://www.anes.org/

- http://www.aderee.ma/

- http://www.apisolar.pt/

- http://www.asit-solar.com/

- http://www.dasolabrava.org.br/

- http://www.epia.org/home/

- http://www.estif.org/

- http://www.giz.de/

- http://www.iea-shc.org/

- http://www.irena.org/

- http://www.mnre.gov.in/

- http://www.ome.org/

- http://www.olade.org/

- www.ren21.net/

- http://sahwia.org/

- http://www.solar-district-heating.eu/

- http://www.solarwirtschaft.de/

- http://www.solrico.com/

- http://www.solarthermalworld.org/

- http://www.swissolar.ch/ 


\subsection{List of Figures}

Figure 1: From countries shown in yellow detailed market data are available. The market data from all other countries are estimated.

Figure 2: Global solar thermal capacity in operation and annual energy yields 2000-2014

Figure 3: Global capacity in operation [GW el], [GW $\mathrm{th}$ ] 2014 and annual energy yields [TWh $\mathrm{el}$, [ $\left[\mathrm{TWh}_{\mathrm{th}}\right]$

(Sources: AEE INTEC, Global Wind Energy Council (GWEC), European PV Industry Association (EPIA),

REN21 - Global Status Reports 2014 and 2015)

Figure 4: Global solar thermal heat, wind power and photovoltaic capacity in operation and market growth rates between 2010 and 2014 (Sources: AEE INTEC, Global Wind Energy Council (GWEC), European PV Industry Association (EPIA), REN21)

Figure 5: Share of the total installed capacity in operation (glazed and unglazed water and air collectors) by economic region at the end of 2013

Figure 6: Distribution of the total installed capacity in operation by collector type in 2013 - WORLD _................ 13

Figure 7: Distribution of the total installed capacity in operation by collector type in 2013 - EUROPE $\ldots \ldots \ldots \ldots \ldots \ldots \ldots$

Figure 8: Top 10 countries of cumulated water collector installations (absolute figures in $\mathrm{MW}_{\mathrm{th}}$ ) $\ldots \ldots \ldots \ldots \ldots \ldots \ldots \ldots$

Figure 9: Top 10 countries of cumulated water collector installations (relative figures in $\mathrm{kW}_{\text {th }}$ per 1,000 inhabitants) $\quad \ldots \quad 14$

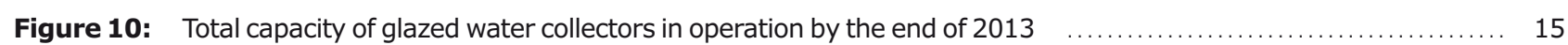

Figure 11: Total capacity of glazed water collectors in operation in $\mathrm{kW}_{\text {th }}$ per 1,000 inhabitants by the end of $2013 \quad \ldots \ldots \ldots$

Figure 12: Total capacity of glazed flat plate and evacuated tube collectors in operation by economic region at the end of 2013

Figure 13: Total capacity of glazed flat plate and evacuated tube collectors in operation by economic region and in $\mathrm{kW}_{\text {th }}$ per 1,000 inhabitants by the end of 2013

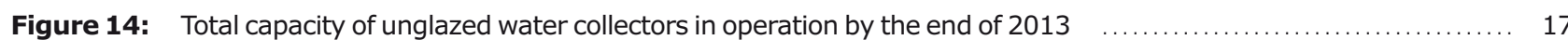

Figure 15: Total capacity of unglazed water collectors in operation in $\mathrm{kW}_{\text {th }}$ per 1,000 inhabitants by the end of $2013 \quad \ldots \ldots$

Figure 16: Share of newly installed capacity (glazed and unglazed water and air collectors) by economic regions in $2013 \quad 18$

Figure 17: Market growth of newly installed capacity (glazed and unglazed water collectors) 2012/2013 by economic region and world-wide

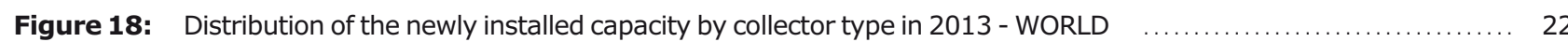

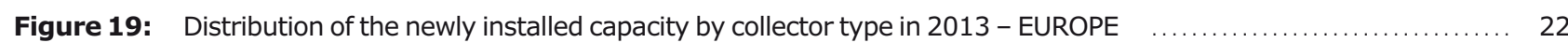

Figure 20: Top 10 markets for glazed and unglazed water collectors in 2013 (absolute figures in $M W_{\text {th }}$ ) $\ldots \ldots \ldots \ldots \ldots \ldots$

Figure 21: Top 10 markets for glazed and unglazed water collectors in 2013 (relative figures in $\mathrm{kW}_{\text {th }}$ per 1,000 inhabitants)

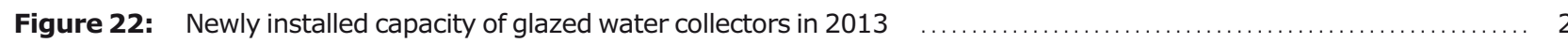

Figure 23: Newly installed capacity of glazed water collectors in 2013 in $\mathrm{kW}_{\text {th }}$ per 1,000 inhabitants $\ldots \ldots \ldots \ldots \ldots \ldots \ldots$

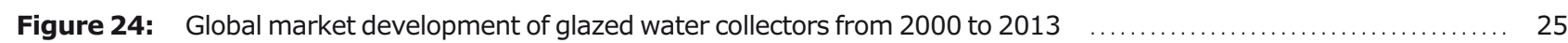

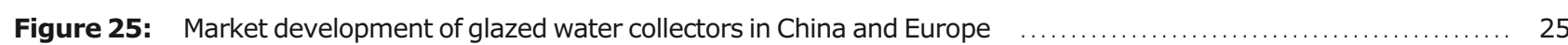

Figure 26: Market development of glazed water collectors in Europe and the rest of the world (RoW, excluding China)

Figure 27: Market development of glazed water collectors in Rest of World (excluding China and Europe) $\quad \ldots \ldots \ldots \ldots \ldots . \ldots 27$

Figure 28: Annual installed capacity of glazed water collectors in $k W_{\text {th }}$ per 1,000 inhabitants from 2000 to $2013 \quad \ldots \ldots \ldots$

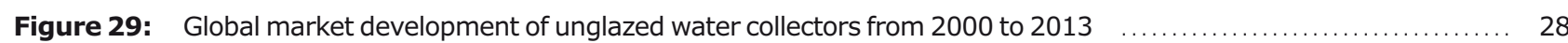

Figure 30: Share of energy savings and $\mathrm{CO}_{2}$ reduction by type of application of glazed and unglazed water collectors in operation by the end of 2013

Figure 31: Annual collector yield of unglazed and glazed water collectors in operation by end of 2013

Figure 32: Annual energy savings in oil equivalent by unglazed and glazed water collectors in operation by end of 2013 
Figure 33: Contribution to $\mathrm{CO}_{2}$ reduction by unglazed and glazed water collectors in operation

by end of 2013

Figure 34: Distribution by type of solar thermal collector for the total installed water collector capacity in operation

by the end of 2013

Figure 35: Distribution by type of solar thermal collector for the newly installed water collector capacity in 2013

Figure 36: Distribution by type of system for the total installed glazed water collector capacity in operation

by the end of 2013

Figure 37: Distribution by type of system for the newly installed glazed water collector capacity in 2013

Figure 38: Distribution of solar thermal systems by application for the total installed water collector capacity

by economic region in operation by the end of 2013

Figure 39: Distribution of solar thermal systems by application for the newly installed water collector capacity by economic region in 2013

Figure 40: Solar district heating and cooling in Europe - annual achievements and cumulated area in operation by end of 2014 (Data source: Jan-Olof Dalenbäck - Chalmers University of Technology, SE)

Figure 41: Solar district heating and cooling in Europe - capacities installed and No. of systems by end of 2014 (Data source: Jan-Olof Dalenbäck - Chalmers University of Technology, SE)

Figure 42: Market development 2004-2014 solar air conditioning and cooling systems in Europe and world-wide (Source: Climasol, EURAC, Fraunhofer ISE, Green Chiller, Rococo, Solem Consulting, Tecsol)

Figure 43: Global solar process heat applications in operation (Source: IEA SHC Task49/IV SHIP database) $\quad \ldots \ldots \ldots . . . .42$

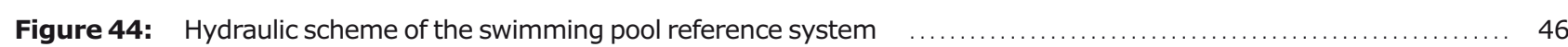

Figure 45: Hydraulic scheme of the domestic hot water pumped reference system for single family houses $\ldots \ldots \ldots \ldots \ldots .48$

Figure 46: Hydraulic scheme of the domestic hot water thermosiphon reference system for single family houses $\quad \ldots . . . .48$

Figure 47: Hydraulic scheme of the domestic hot water pumped reference system for multifamily houses $\ldots \ldots \ldots \ldots \ldots .50$

Figure 48: Hydraulic scheme of the solar-combi reference system for single and multifamily houses $\ldots \ldots \ldots \ldots \ldots \ldots \ldots$

\subsection{List of Tables}

Table 1: Total capacity in operation by the end of 2013 [MW

Table 5: Calculated annual collector yield and corresponding oil equivalent and $\mathrm{CO}_{2}$ reduction of glazed and unglazed water collectors in operation by the end of 2013

Table 9: Solar combi system reference for single and multifamily houses and the total collector area in operation in 2013

Table 10: Reference climates for the 60 countries surveyed

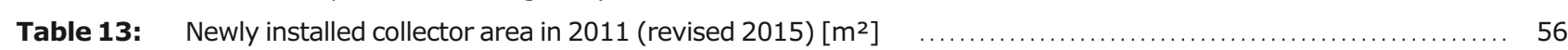

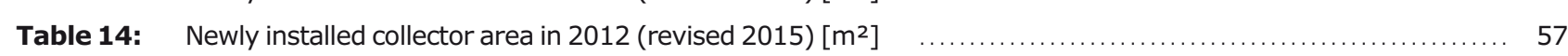

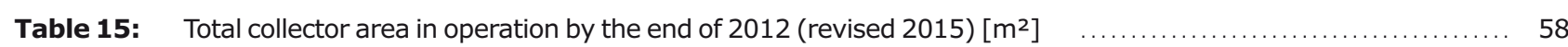

